\title{
ESTADO, CONSTITUCIÓN Y FORMA DE GOBIERNO EN JOVELLANOS
}

\author{
Ignacio FERNANDEZ SARASOLA
}

\section{Introducción}

Pocas dudas puede haber de que Jovellanos es un hombre clave en la his. toria del pensamiento político español. Pero, como suele suceder con las personas sobresalientes, su ideario resulta difícil de calificar. Los vacilantes y ambiguos principios de la teoría política de Jovellanos permitieron que bajo su capa se defendiesen las más dispares posiciones constitucionales: durante el proceso constituyente gaditano que sucedió inmediatamente a la muerte del gijonés los sectores "realista" y liberal acudieron por igual al ilustre asturiano, en un intento de revestir de auctoritas sus argumentos'. Y esta misma ambigüedad explica la variedad de interpretaciones que Jovellanos ha suscitado después.

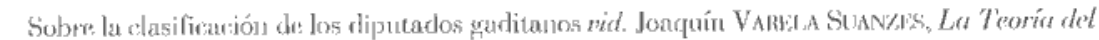
Esterto en los origenes det constiturionatisme español (Las Corfes de Cádiz), Madrid, Cantro de

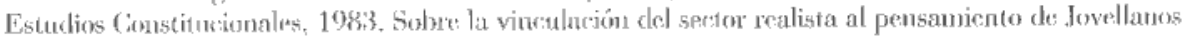
consíltense especialsuente las págs. 13-15 y 144 y s.s. Por otra parte, un liberal como Quintaua no

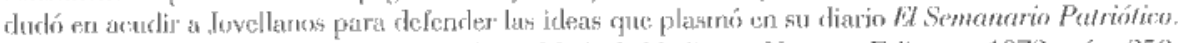

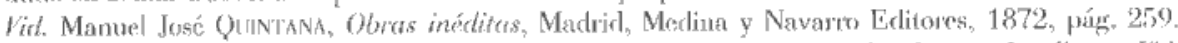

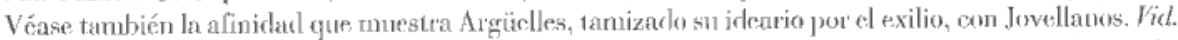

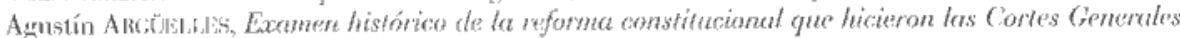

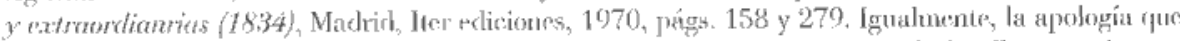

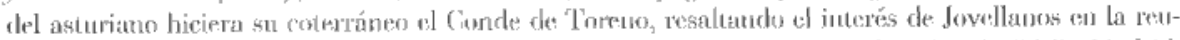

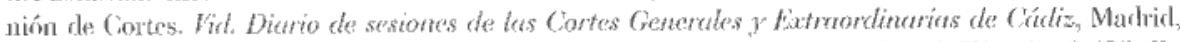
Iuprenta de J. A. Carcía,1870, besión núm. 441, 17 de dicienbe de 1811, vol. IV, pág. 2.433. En

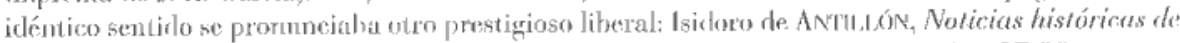
D. Getspur Methor de Jobellenos, Palma, impernta de Miguel Domingo, 1812, págs. 37-39.
} 
Resulta sojprendente comprobar cómo se ha clasificado el pensaniento de Jovellanos en tendencias dianetralmente opuestas. Aun bajo riesgo de resultar en exceso simplificarlor, bien puede decirse que existen cuatro grandes vías interpretativas de la doctrina político-constitucional de Invellanos. En primer lugar, se há visto en el gijonés un conservador, dentro de la liuma "auténtica y ortodoxa del tradicionalismo español", como afirmó Jesís Evaristo Casariego $0^{2}$ o, en la misma línea, Ignacio Elizalfe, yue insiste en que "los ralificativos fle servil y absolutista (...) le cuadrarían perfectanente»" En sote nismo sentido, Villota encuentra en el escolesticismo la principal fíliación rlel gijónes, hasta el punto de negar originalislarl a su pensamionto, que tan sólo spguiría la estela del tomismot. Lin el extremo contrario, el profesor Ciaso Conzúlez (sin duda alguna el mayor esurlioso del inmortal asturiamo) ve en lovellanos a un demócrata. las críticas que Jovellanos vertió

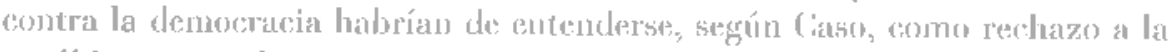
república como forma de Fistado, pero no a la denos racia como forma de

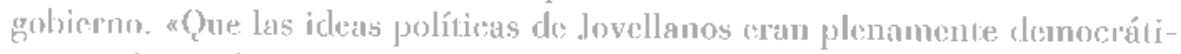

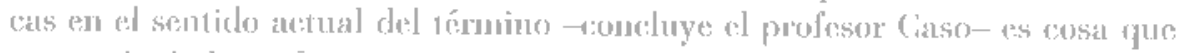
no puede dudarson".

Desele, ma tereera perspectivá, Raúl Morodo y Moreno Alouso manticnen que Jovella nos era un déspolat ilustrado"; y de firme convieción, puesto que esia adscriprión al despotismo, nacida bajo el reinado de Carlon III, la mantendría todavía en la Cuerra de lat Independencia?. Finalmenté, no está menos exten-

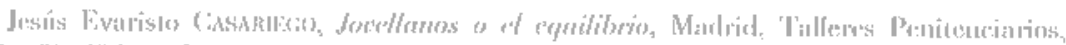

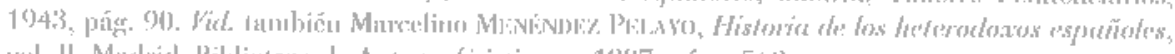

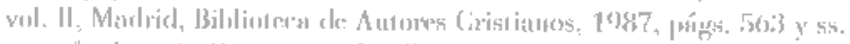

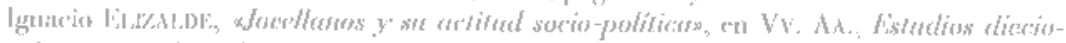

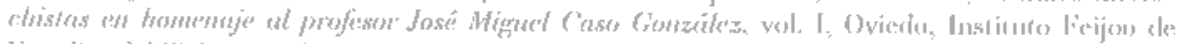

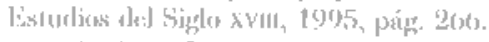

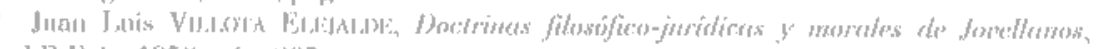

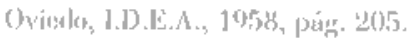

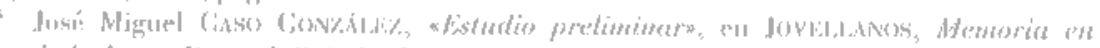

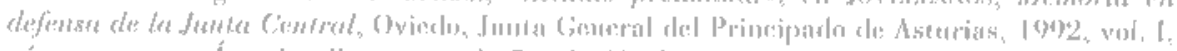

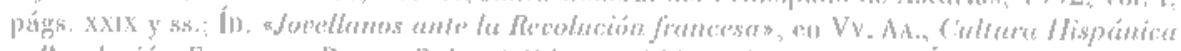

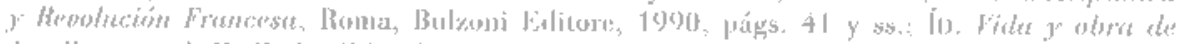

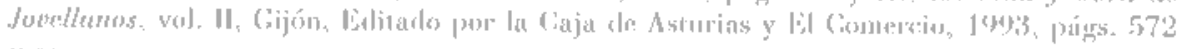
Y ss.

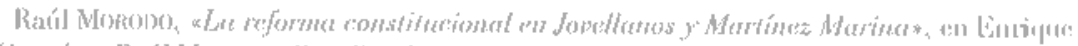

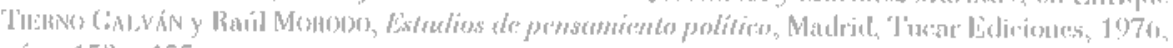
páng. 153 y 155. pig. 10:3.

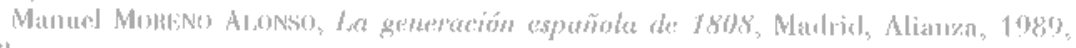


dicla la idea del Jovellanos liberal", máxime cuando el haber formado parte del liberalismo parece considerarse hoy como una especie de mérito, de la misma manera que para el profesor Menéndez Pelayo llegó a constituir una herejía. Un mérito que no debe faltar en personaje tan insigne como Jovellanos.

De Jovellanos hay, pues, tantas lecuras como lectores. ¿Debemos, por tanto, renunciar a clasificar su pensamiento? Sin duda scría lo más fácil, pero un personaje de tanto relieve bien merece un esfuerzo. Pero antes deben ponerse en claro los términos de la discusión, los parámetros que van a utilizarse para concluir en cqué molde encaja el ideario polírico jovellanista. Apuntémoslos.

En primer lugar, el análisis del pensamiento de Jovellanos obliga a sumergirse en su vasta obra. Nada más engañoso que leer tan sólo las obras de «lectura obligada», preteriendo las restantes. Por el contrario, Jovellanos deja caer ideas político-constitucionales de suma importancia en los textos más insospechados, en tanto que otras obras, consideradas cono la más alta expresión de su pensamicnto, som excepciones dentro de un ideario con notas de consistencia. No debe cometarse el error de tomar la parte por el todo, la excepción por la regla general.

Segundo punto que interesa aclarar: el pensamiento de Jovellanos, como resulta perfectamente lógico, es evolutivo, cambiante". Además, el asturiano no expresa por igual sus ideas en las obras destinadas al público general que en su correspondencia privada o en sus diarios ${ }^{t 0}$. Ahora lien, estamos lejos de creer que Jovellanos padecía una especie de «esquizofrenia intelectual». Por el

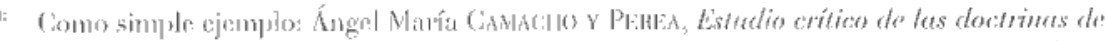

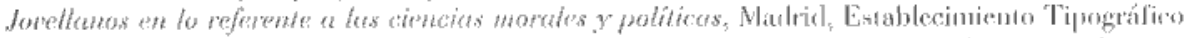

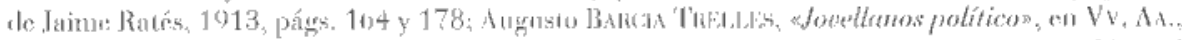

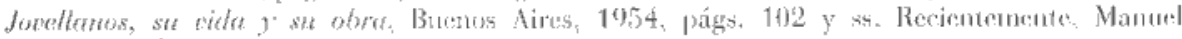

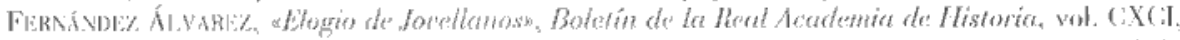

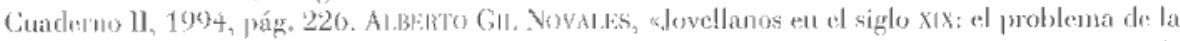

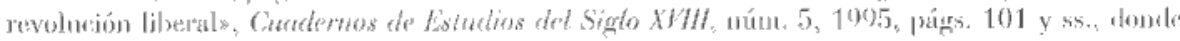

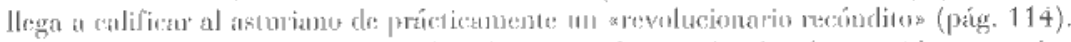

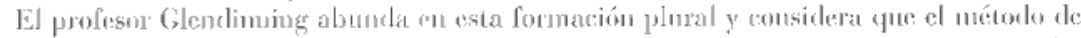

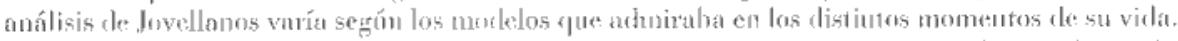

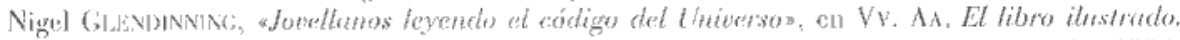

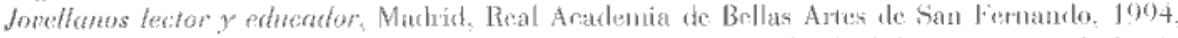

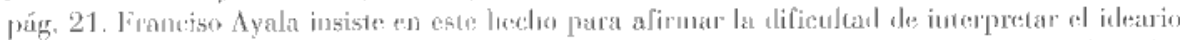

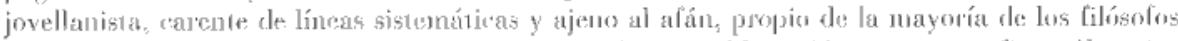

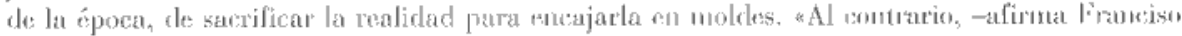

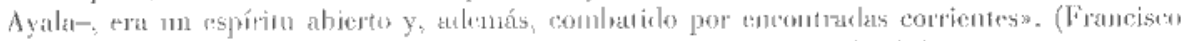

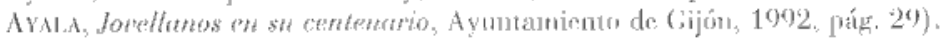

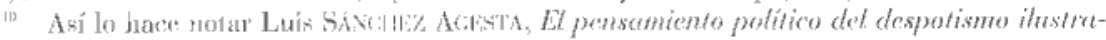
(to) Sevilla, Universidad de Sevilla, 1979, pág. 189 . 
contrario, a pesar de su evolución lógica hay elementos uniformes y una nota de coherencia on su pensamiento. Por otra parte, diarios y epístolas en ningúu caso contradicen lo plasmado en documentos de otra índole; simplemente en estos últimos expresa las mismas idens de forma más moderada. ¿̨) es que acaso el foro no condiciona siempre las palabras?

Por último, resulta fílil decir que Jovellanos cra políticanente un liberal o un conservador si se utilizan criterios subjetivos; a mayor abundániento cuando es frecuente extrapolar al pasado categorías actuales. Por tanto, y toda vez que se trata de clasilicar un ideario político-constitucional, ha de partirse de categorías a lave para las distintas tendencias en que portría encajar el ideario del asturiano. ¿Y cuáles sun éstas? Ia concepción del Estado y sociedad, de la Constitución y de las formas de gobierno. Todo movimiento político-ronstiiucional (ya sea escolástico, liberal-conservador, liberal-demoerático, afín al despotismo ilustrado...) parte de una forma do concehir estas cuestiones, y al resto de elementos relacionados (idea de libertad, o de las libertades concretas, reformas propuestas...) no son sino su expresión y fousecuencia.

A lo largo del presente trabajo se analizarún las opiniones do Jovellanos en cstos términos, para concluir expresando nuestra postura solse la tiliación de este areformista bienientencionadon, conto lo calificó Marx".

\section{TEOHA DEL ESTADO}

En el úlvimo tereio dell sigio XVIII y comirnans del XIX en España, que es ol momento histórico que vera vivir a Jovellanos, se produjo una crisis del cortrepto tradicional de sociedad y Estadn. Frente a las concepcinnes nenescolásdicas que, particndo de las doctrinas aristotólicas reformuladas por santo Tomás de Aquino, afirmaban la socialuilidad del hombre y la soberanía actual del Monara, fruto de un pacto de traslación (manslatio imperie), se incrudujeron en uuestra nación las modernas tendencias iusnaturalistas. Con cllas se abrió paso el racionalismo cartesiano y la idea dell hus Naturale y el hos Gentum como Derechos suprapositivos válidos sn todta sociedad. No obstante, cabe distinguir dos icndencias: por una parte, aquel iusnaturalismo más tributario rlel escolasticismo, como es al caso de] prolesado por (rrocio o Vatel, que afirmaban la sociabilidad del hombre o, ał menos, su clara tendencia social y que, paralelamente, mantienen un origen pacticio de la sociedad y del Estado

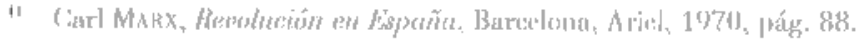


en una linea aproxinada a la idea de pactum soctetatis y pactum subjectionis suarecina. Por otra, encontramos las posturas más rupturistas de Hobbes. Spinoza, Helvecio o Kan, que partían del estado de naturaleza y de ma idea no bilateral del pacto social como origen del Estado y la sociedad.

\section{El estado "presociat»}

Jovellanos adopra como punto de partida la sociabilidad natural del hombre ${ }^{\prime 2}$, siguiendo, así, no sólo al aristotelismo, sino la también a gran parte del imsnaturalismo racionalista de los siglos XVII y XVII. A pesar de que su postura es ambigua y lace diversas feferencias al «estado natural del hombres ${ }^{13}$, debe contenderse éste cono mn estado asociativo más o menos imperfecto. previo tan sólo a la constitución de la sociedat civil, tal y como pensaba también Filangieri ${ }^{1+}$, o como postulaba Burlanaqui. Este último distingúa entre esta dos primitivos del hombre, doude ubicaba al estado de sociedad, y ostados accesorios, olora ded hombre, y donde: se encontraba la sociedad civilis.

Fvitando caer en una mera afimación apodíctica, el asturiano aportaba una doble argumentación, racionalista la una, de carácter histórico la

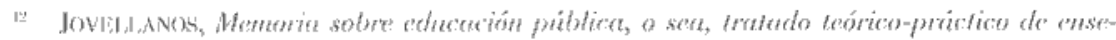

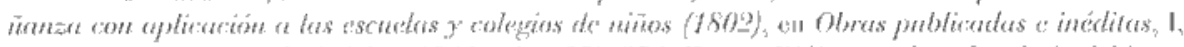

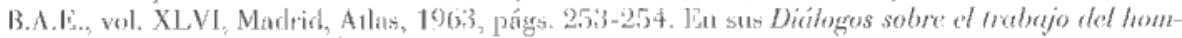

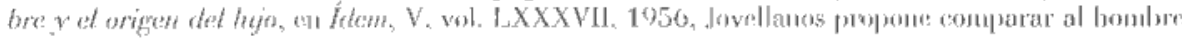

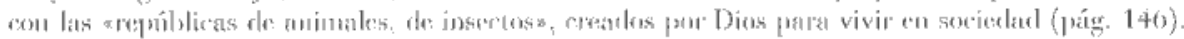

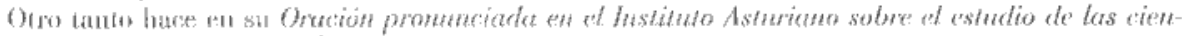

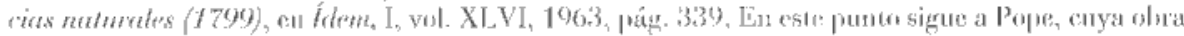

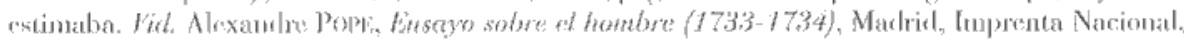

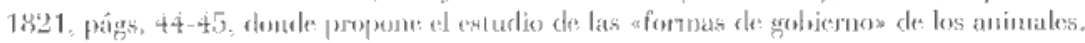

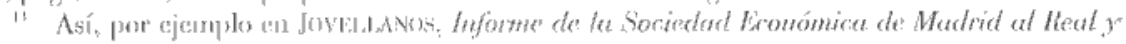

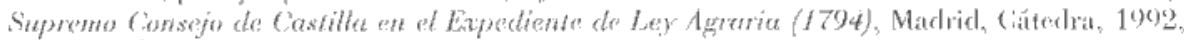

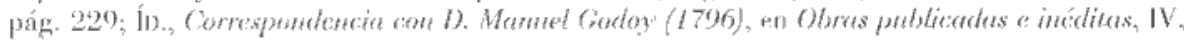

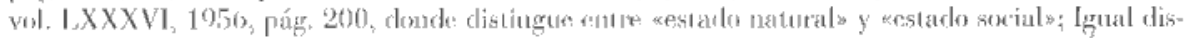

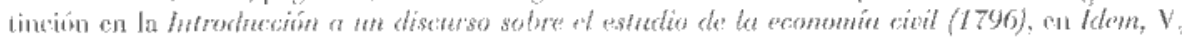
vol. I,XXXVIl, prig. 17.

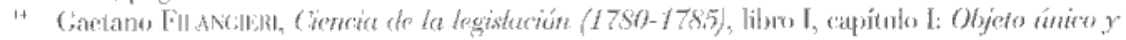

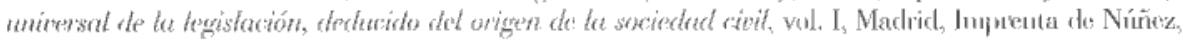

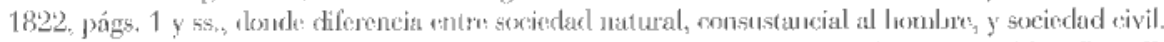

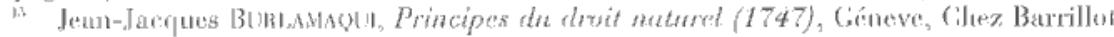

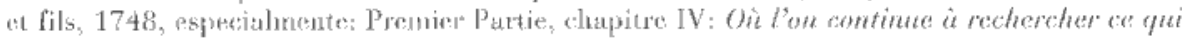

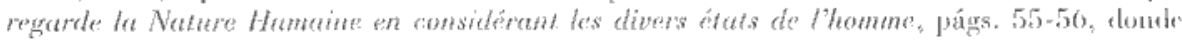

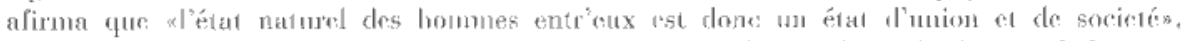

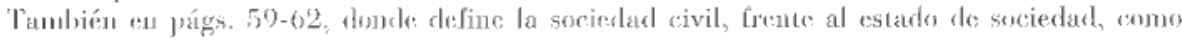

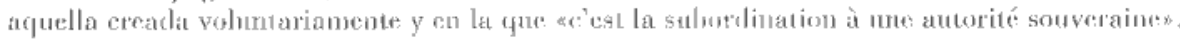




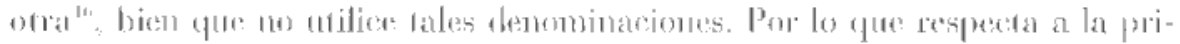

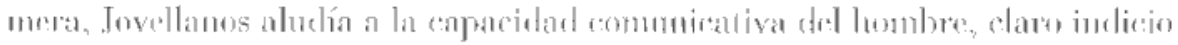

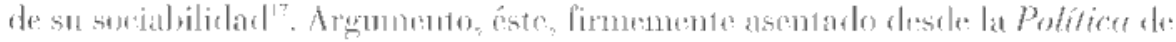

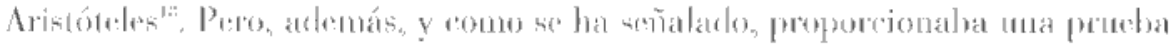

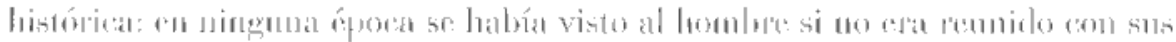

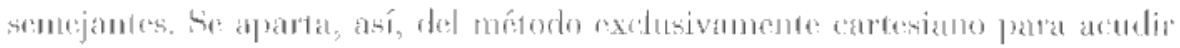

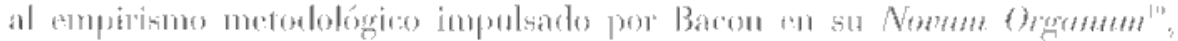

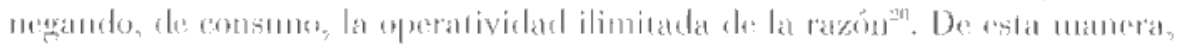

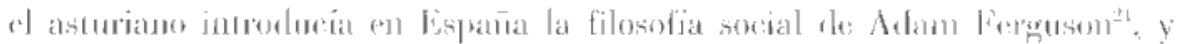

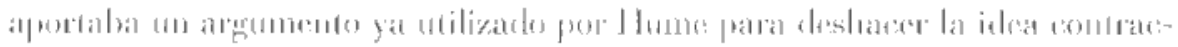

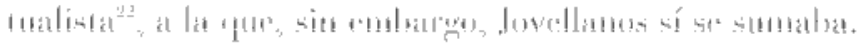

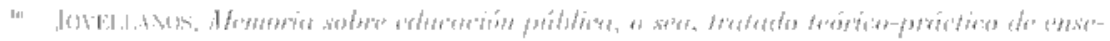

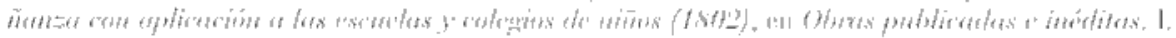

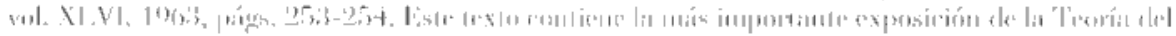

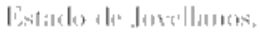

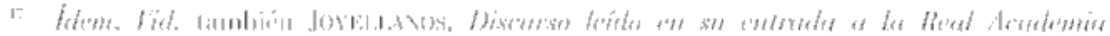

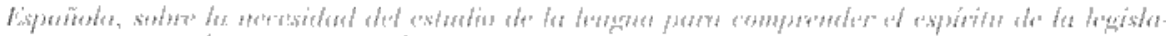

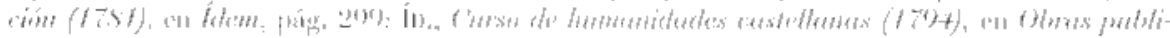

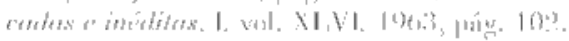

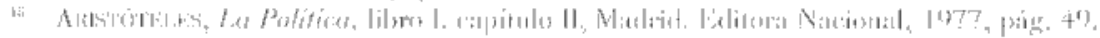

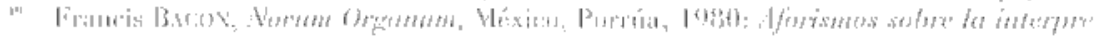

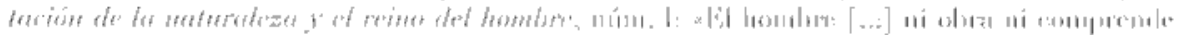

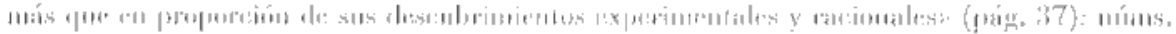

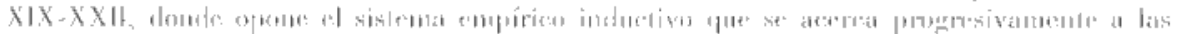

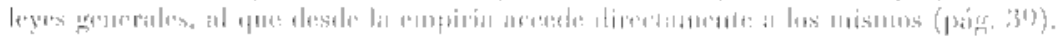

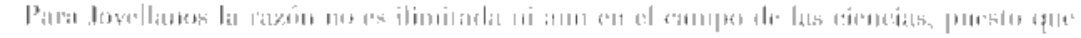

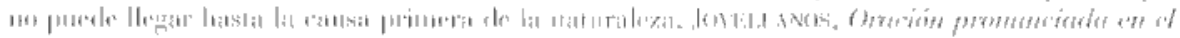

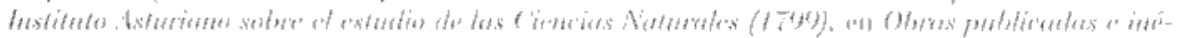

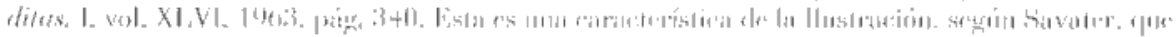

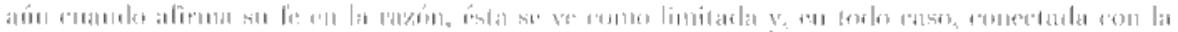

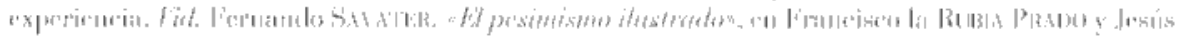

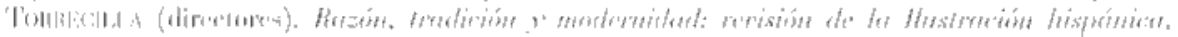

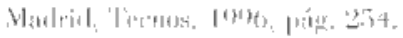

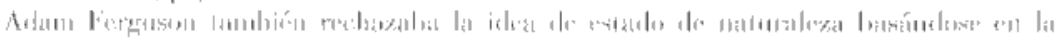

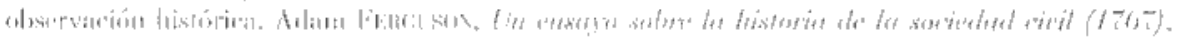

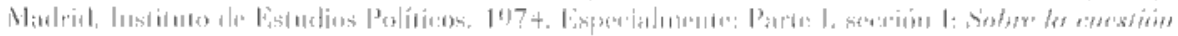

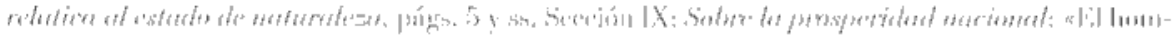

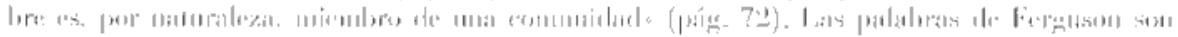

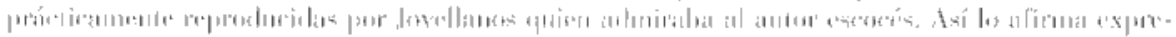

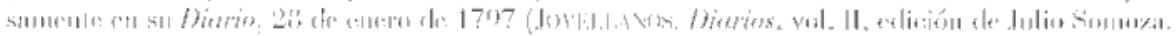

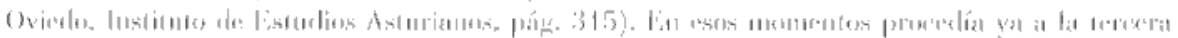

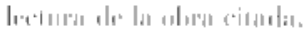

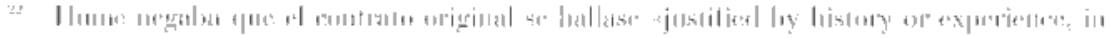

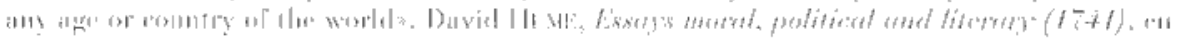


El fundamento de la sociabilidad del hombre se encontraba en el origen divino de la ley natural. Electivamente, frente a Hobbes ${ }^{2.1}$ y Spinoza ${ }^{24}$, el gijonés no buscaba cl origen del Derecho Natural en la naturaleza humana, sino, como hiciera Grocio ${ }^{25}$, en Dios. Una tendencia, ésta, constante en el pensamiento jovellanista, que reconducía el estudio de la ética a la ontología ${ }^{2 *}$. La indagación racional de la ley natural a través del estudio del hombre era sólo posible en cuanto Dios la había grabado en su naturaleza ${ }^{27}$. Concretamente, el contenido de esta ley natural era el amor, en su doble dimensión de amor a Dios y amor recíproco entre los hombres. En este punto, Jovellanos seguía de cerca las teorias de Heineccio ${ }^{2 R}$ y Donat ${ }^{2 n t}$.

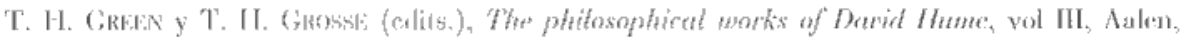

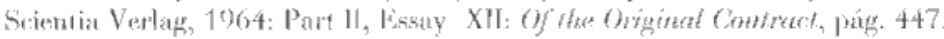

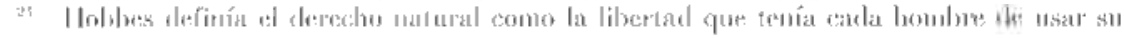

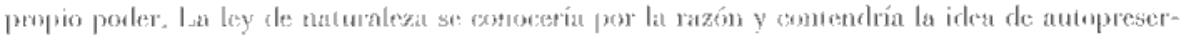

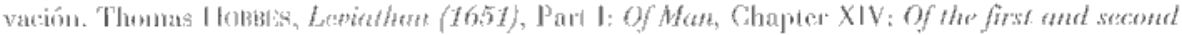

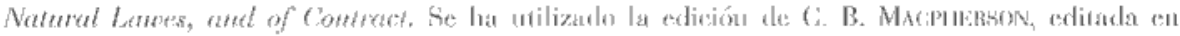
Pronguin Bonks, I ondires, 1984, príg. 189

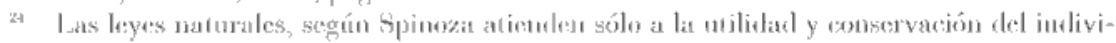

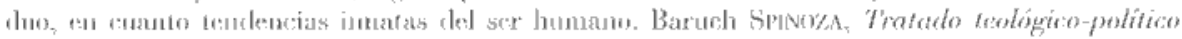

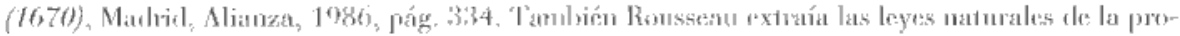

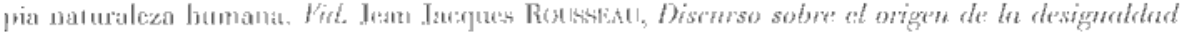
entre los hombers (1755), Madrid. Aguilar, 1973, págs. 21-22.

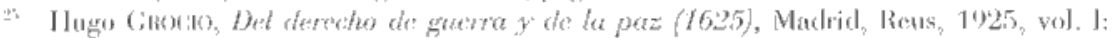

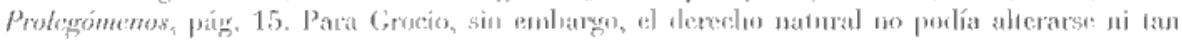

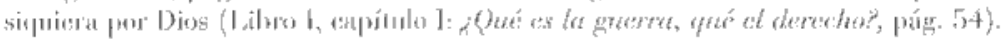

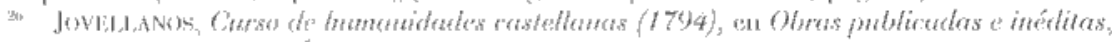

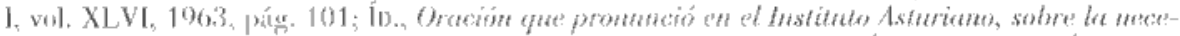

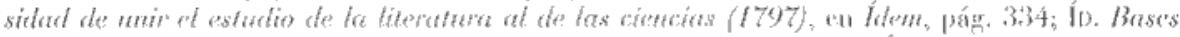

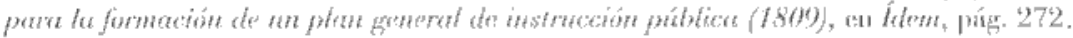

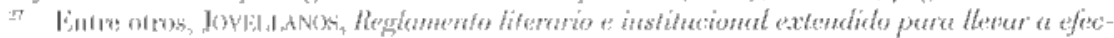

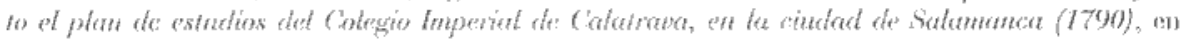

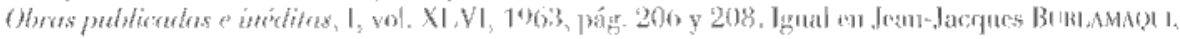

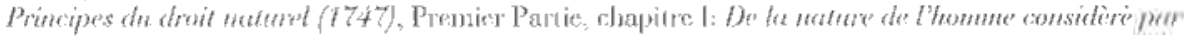

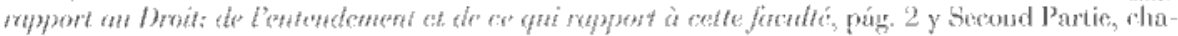

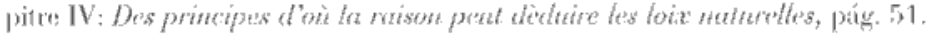

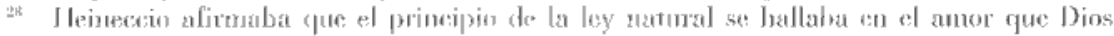

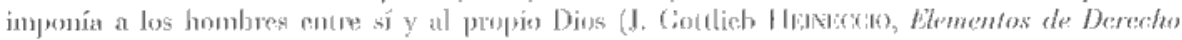

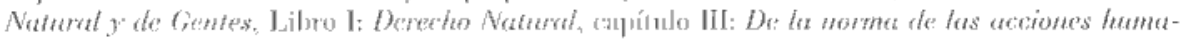

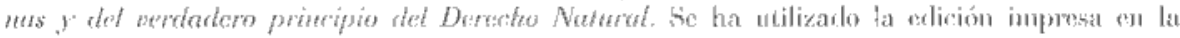

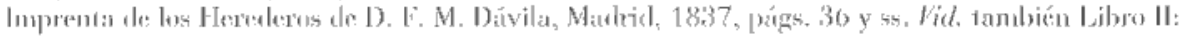

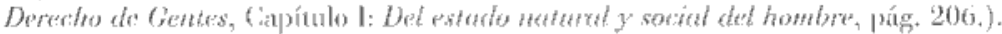

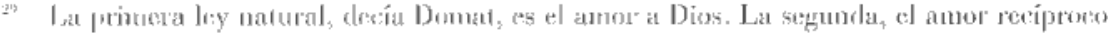

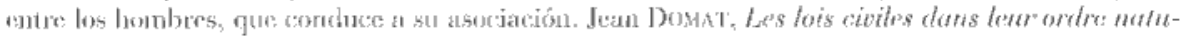

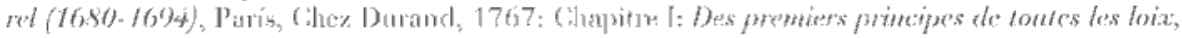


El fin del hombre, insito a su naturaleza, era, pues, al amor; un fin trascendente, no immanente. Con tal afimacion Jovellanos se oponía nuevamente a Iobbes y a su afirmación de la iniquidad de la especie humana; una maldad congénita gue fundamentaría el exacerhado individualismo del inglés. Ahorá bien, téngase en cuenta que esta *ley natural del amor» 10 supone una simple negación de la ideá de «estado de guerra», sino la misma negación del estado de naturale$\mathrm{za}^{\text {in }}$. Y es que ese amos mutuo que fundamentaba la sociabilidad humana hacía rpue fuese imposible un rstado de aislamiento. Tha situación tal no sería tan idilica como mostrara Rousseau", sino una auténtica quimera en la que los hombres 110 podrian desatrollar sus capacidades físicas y morales, ni amplir an la liy natural implesta por Dios.

Phesto que la ley natural del aunor recíproco resultaba comíu, romo es obvio, a toda la espocie humana, Jovellanos postulaba una asociación general drit hombre, lo cue bien podría llamarse nua Universitos. ¿Era posible tal asociación universal?

\section{La formacion de la sociedar rivil}

Los vínculos universales del género humano se verían circunscrios a agrupaciones más nodestas, ciñéndose el amor natural *a círculos más x'eda-

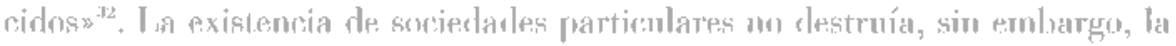

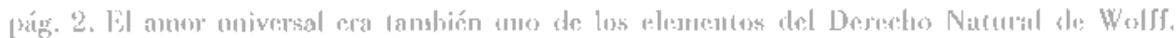

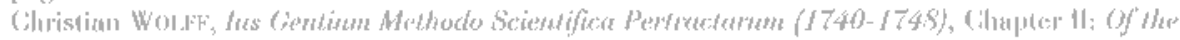

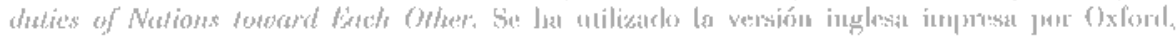

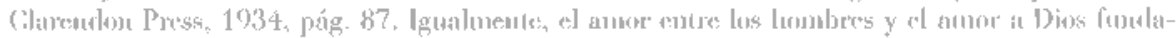

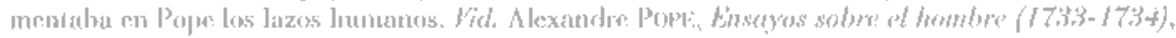
jets. 75 .

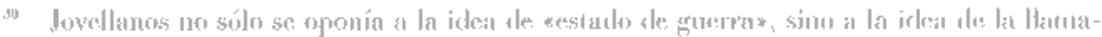

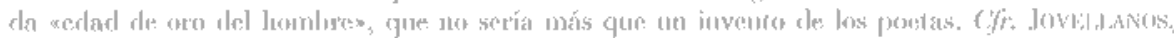

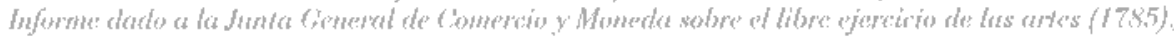

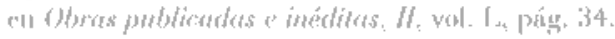

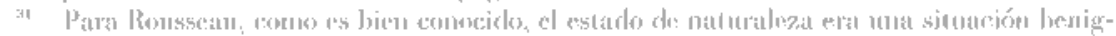

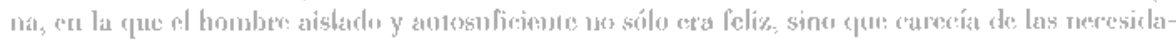

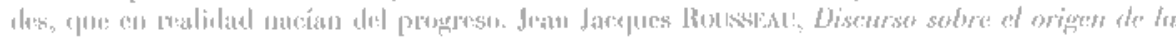

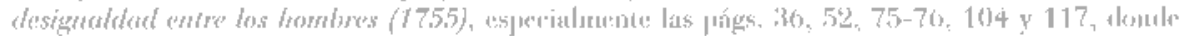

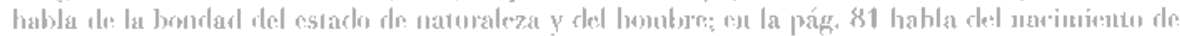
lats neresidades (on) lat suriedat.

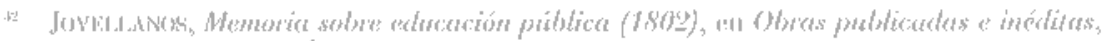

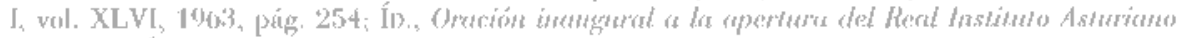

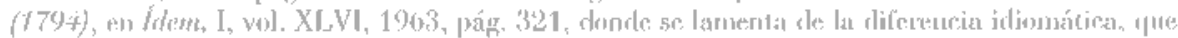

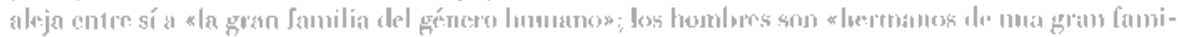

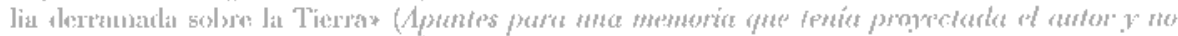

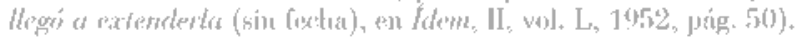


tendencia miversal, del mismo modo en que Christian Wollf afimaba la compatibilidad de la sociedad universal con las particulares ${ }^{\text {tal }}$. Esta limitación derivaría de la dispersión del hombre por el mundo, con todas las rabas que imponían los condicionantes geofísicos y gue, como más tarde se verá, modulaba el caráter de cada ma de estas agrupaciones. Unas agrupaciones que, sucesivamente, iban descte las familias hasta las tribus, y de ésias a los pueblos y suie(lades ${ }^{*}$. En este sentido, el poligrafo gijonés muestra un claro organicismo, tan propio del iusnaturalismo germámico al que se adscribíat.

A pesar de que Jovellanos niega el estado do naturaleza, reconoce in momento asociativo. Ahora bien, debe entenderse que este no es sino la plasmación de la terdencia natural de sociabilidad" ${ }^{5}$. Una tendencia, que, no obstante, Jovellanos pone en entreclicho de forma paradójica al exponer que la sociedad se formaba voluntariamente para evitar "los insultos de la fuerza y las asechanzas de la astucia * ; contradicción en que, no obstante, había caído tambien Pufendorf ${ }^{\text {t. }}$. Es posible que Jovellanos estuviera pensando en la posibilidad te que determinados sujetos antepusiesen el amor propio al afecto muruo, como pusiera de manifiesto Domat".

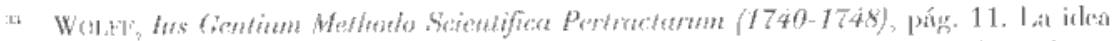

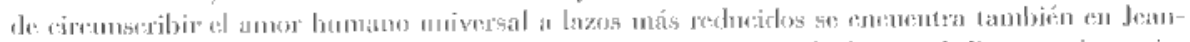

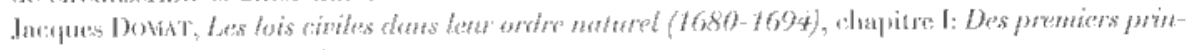
cipes de tounes les hoix, pág. 6.

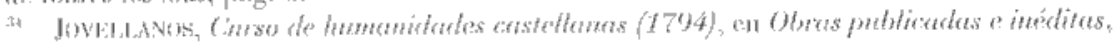
I, vol. XI,VI, 1063. pám 102

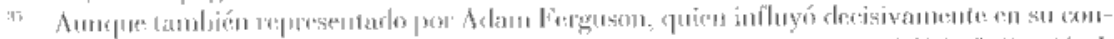

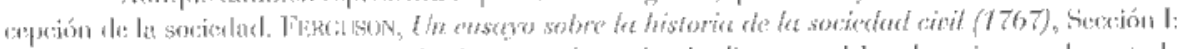

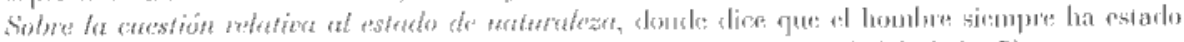

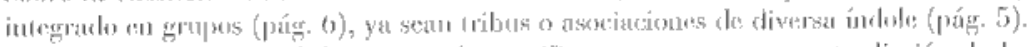

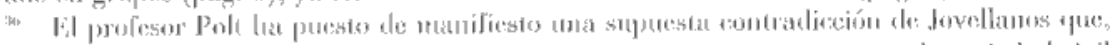

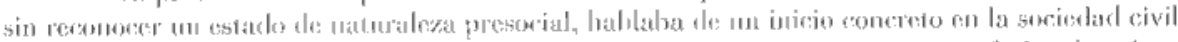

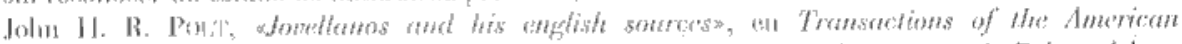

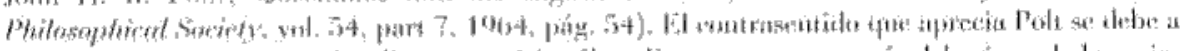

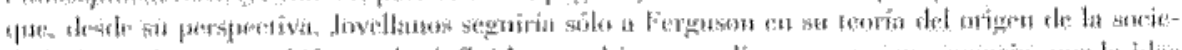

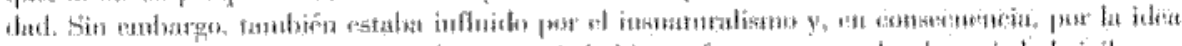

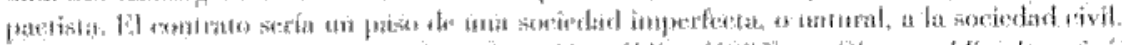

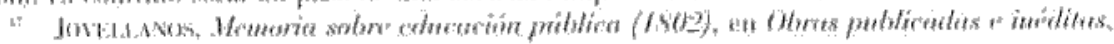

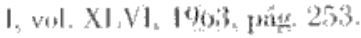

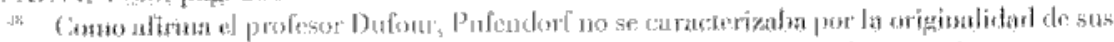

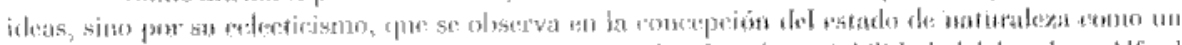

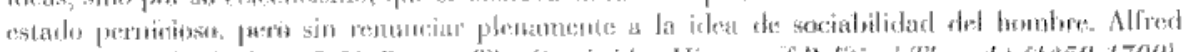

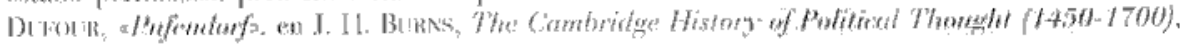

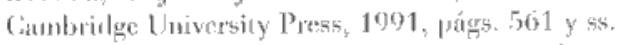

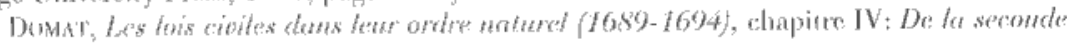
spece d'engugremerts pág. 6. 
La sociedad civil se formaba a través de un pacto sucial o ley fundamental, que el gijonés no confundía con la Constitución, como habrá ocasión de ver. Mediante este pacto se perfeccionaban las obligaciones y libertades recíprocas de los hombres impuestas por la ley natural y se circunscribían a las relaciones concretas de un grupo determinado; más precisamente, al Derecho Público, esto es, la regulación de las relaciones entre el Estado resultante de la asociación y sus miembros, y del Derecho Privado, que se refiería á las relaciones intersubjetivas ${ }^{t !}$.

De esta manera, la sociedad civil perfecenona las obliguciones y libertades naturales ${ }^{*}$. Frente a las teorías contractualistas liberales, a tenor de las que la suciedad civil procede a una imitación lo más fídedigna posible de las libertades naturales, para Jovellanos la suciedad las mejora. Pero, junto a las obligaciones naturales, surgían entonces ntevas ohligariones específicas respecto de los miembros de la sociedad concreta a la que el individuo pertenecia ${ }^{42}$ : "¿ $P$ or ventura es la sociedad otra cosa que ula gran compañía en que cada uno pone sus fuerzas y sus luces, y las consagr'a al bien de los deinás? \$

Auncue en este aspecto Jovellanos se muestra oscures, es posible conchuir que la constitución de la sociedad y del Estado tenía lugar mediante un único pacto, a diferencia de las doctrinas escolásticas. Un auténtico pacto social en que cada individuo procedía a una renuncir prarrial de «una porción de su independencia para componer la autoridad pública; segundo, una porción de su fuerza personal para formar la fucrza pública; tercero, una poreión de su

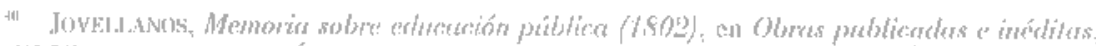

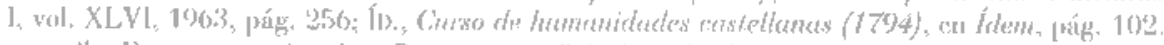

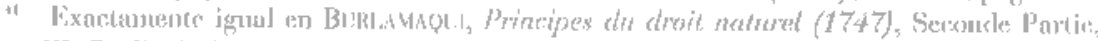
chapitre VI: Du Droit des' (jens, púg. 110.

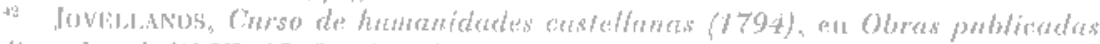

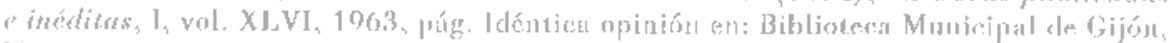

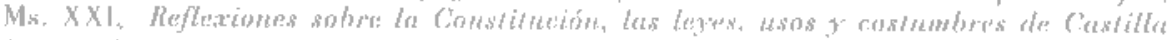

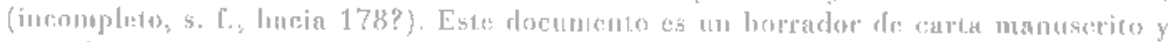

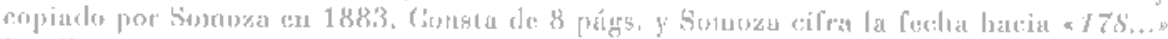

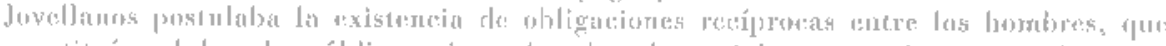

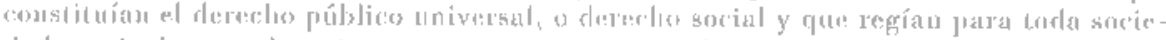

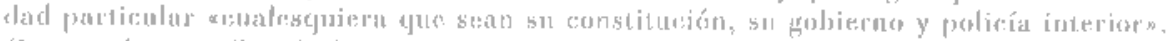

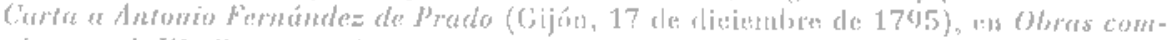

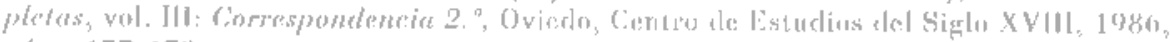
priess. $177-178$.

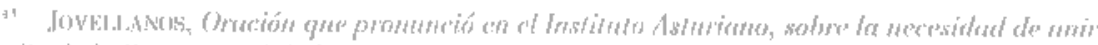

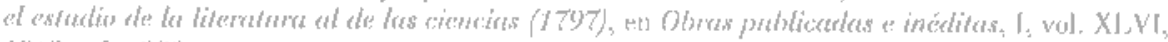
1003. ping. 3333. 
fortuna privada para juniar la renta pública». En la reunión de estos sacrilicios, afirma, "se hallan los elementos esenciales del poder del Estado» ${ }^{44}$.

En este punto Jovellanos sigue absolutamente las doctrinas pactistas del iusnaturalismo racionalista. Por otra parte, es de destacar que la renuncia a los derechos individuales no es absoluta ni incondicional. No es absoluta, puesto que, como se ha transcrito, se sacrifica tan sólo parte de la independencia, de ta luerza personal y de la fortuna privada. En este sentido, Jovellanos se distancia de las teorías pactistas de Hobbes y Spinoza, pero también de Locke. ubicándose en la órbita de Beccaríat. Pero, por otra parte, la renuncia no es incondicional, puesto que el Estado se halla sujeto a la obligación de proteger el pleno goce de los derechos "residuales" *".

De esta manera el asturiano imprime una orientación teleológica al Estado, que nace: y se fundanenta en la protección del individuo, en la salvaguardia de su liberiad y de su propiedad. Esta garantía de la propiedad constituye un elemento esencial ex el pensamiento de Jovellanos, precursor a la sazón de la econonía política en nuestro país, y, a la par, obliga a replantcarse la imagen del Jovellanos afín al Despotismo llustrado. Sin perjuicio de la

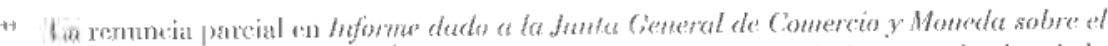
libre ejercicie de les. artes (1755), cn felem, II, vol. L, 1952, prigs. 30 y 40 . Como en l acke, de la

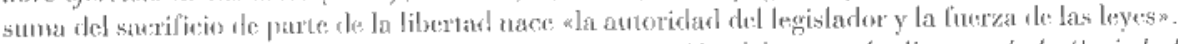

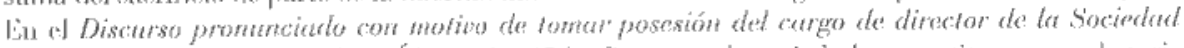

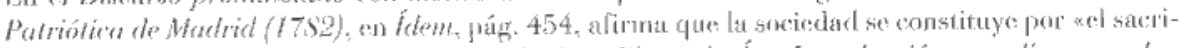

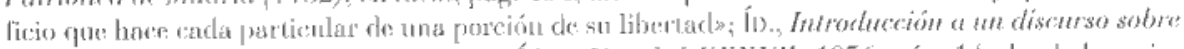

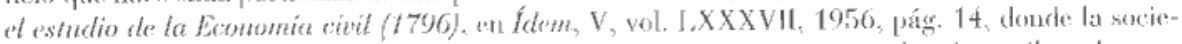

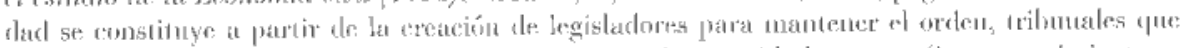

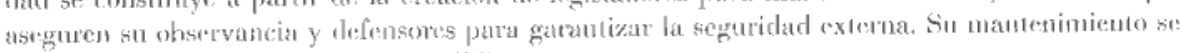
Ilevaria a rabo a través de la renta pribliea.

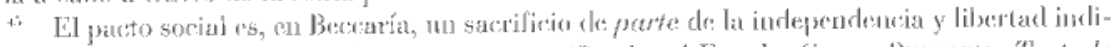

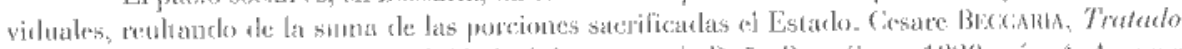

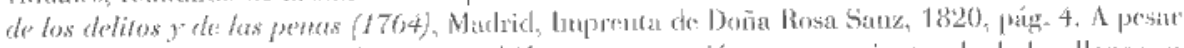
de las diferencias claras, puede verse 1 ambién una conetereión muy semejante a la de Jovellanos con

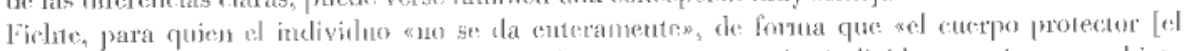

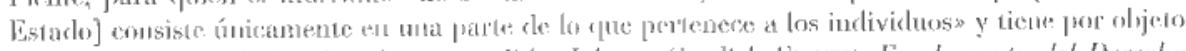

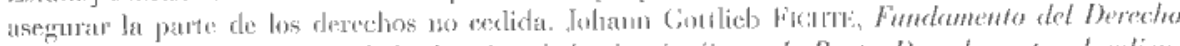

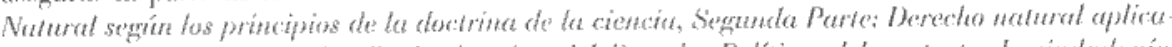

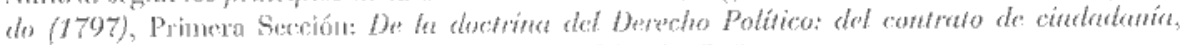

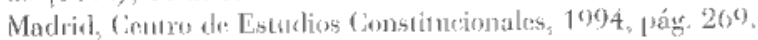

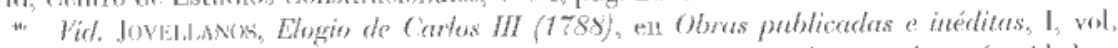

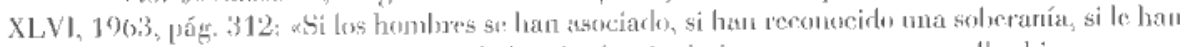

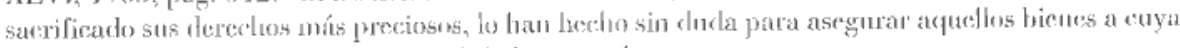
posesión los arrasiraba ol voro general de la nalualezay. 


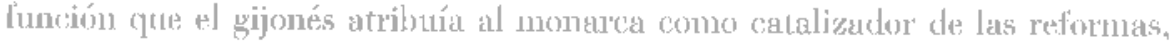

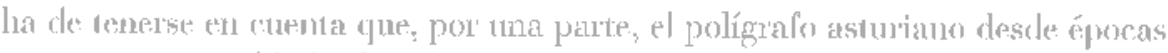

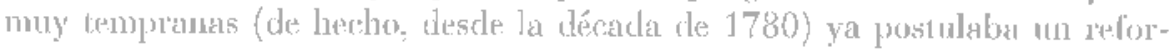
mismo de las propias institueiones, abogando por la jutroduceión de las ciontes

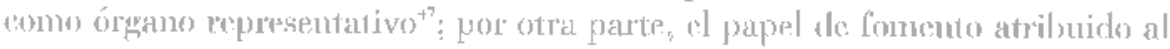
tivular de la Comoma se dirigía, esencialmente, a "fuc foste procarase una ade-

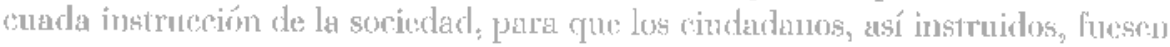

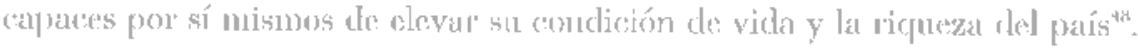

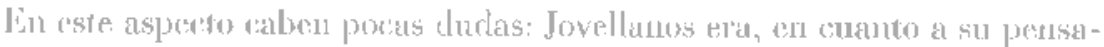
mientor de economía pelítica, un liberal. Ann culandu defendiese inicialnente

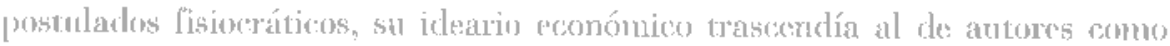

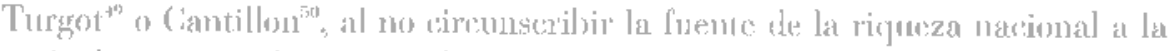

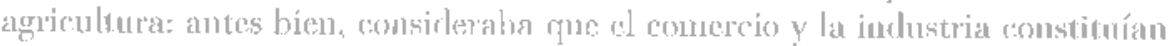

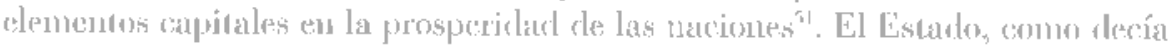

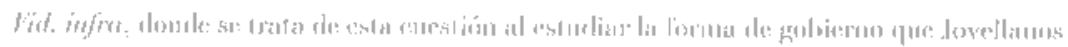

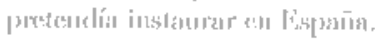

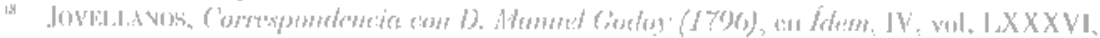

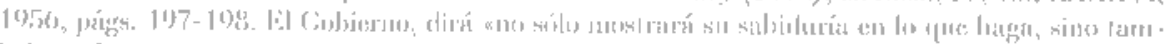

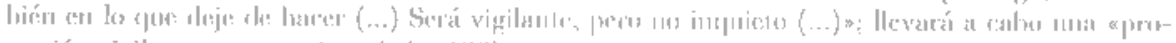

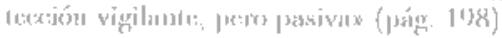

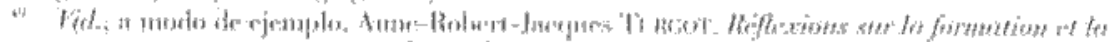

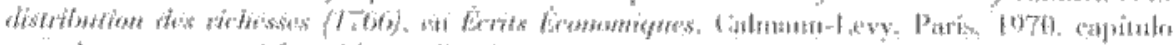

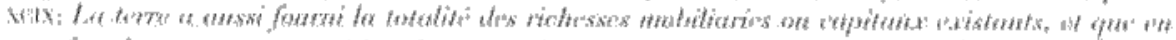

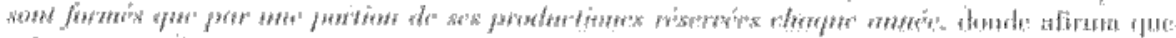

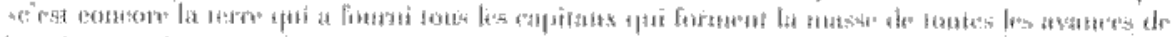

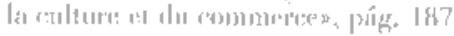

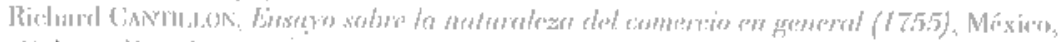

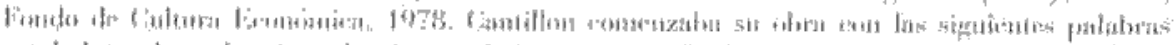

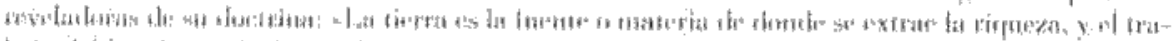

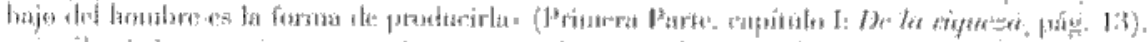

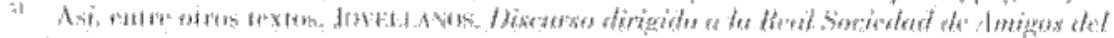

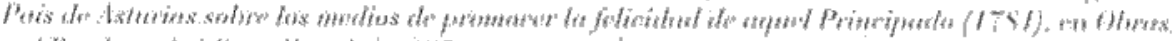

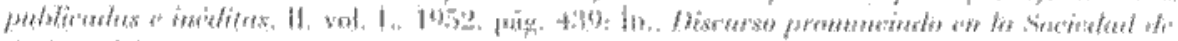

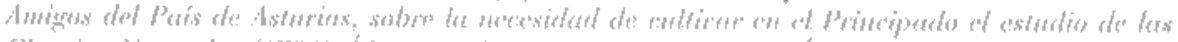

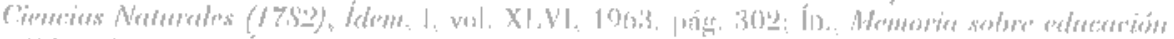

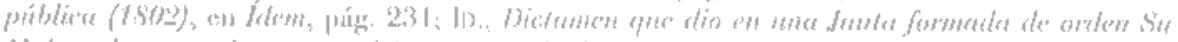

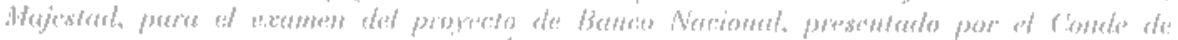

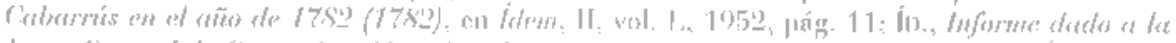

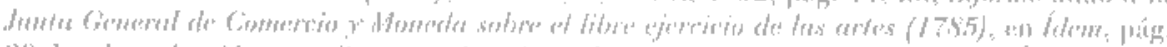
3.

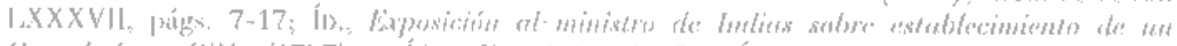

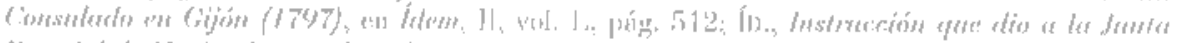

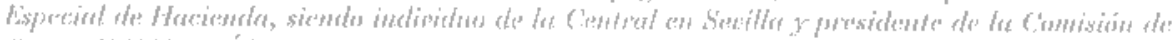

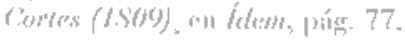


su admirado Adam Smith, debía limitarse a permitio el libre juego y actuación de los actores económicos, eiñóndose a remover los obstáculos que los pertubasen ${ }^{52}$. La constante en Jovellanos será buscar un Estaclo de laissez-faire.

El concepto de propiedad alcanza en Jovellanos una capital importancia para explicar el origen de la sociedad civil, puesto que, como sucede en Locke, éste se construía básicamente para su salvagnardia. El nacimiento de la idea de propiedad hacía que el hombre requiriese de protecoión y actuaba, así, como uno de los prins movens de la construcción del Estado ${ }^{\circ}$.

Formada la suciedad civil y a lestaclo a traves de la renumeia de derechos subjedivos surgía una mueva upegunta jquién ejerceria la dirección política de la comunidad? Para Jovellamos la respuesta se labllaba en la forma de gobierno elegida a través de la Constitución.

\section{TEORIA DE LA CONSTITVOION}

\section{La «Onstitución material»}

El concepio jovellanista de Constitución no es unitario. Antes bien, y como ha puesto de manifiesto Baras Fscolá, en este aspecto se ve un claro proceso evolutivo ${ }^{5+1}$. Inisialmente Jovehlanos empleo el rémino Comstioución para referiste al entramado sociah, políico y económico de la socicdad. Fn este sentido, mantenía um comceplo daramente clásico, al modo aristotélico, en el que Considución no tenía simo un carácter meramente descriptivorís. Sin

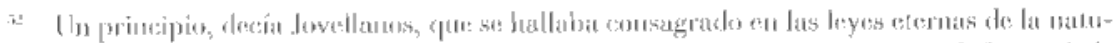

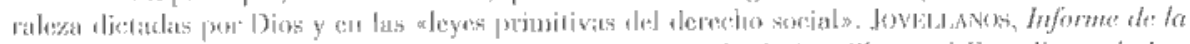

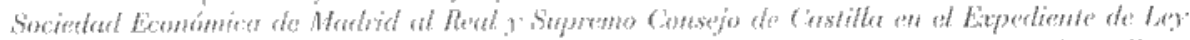

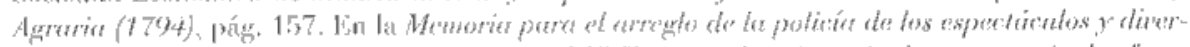

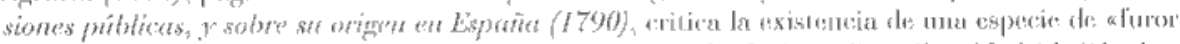

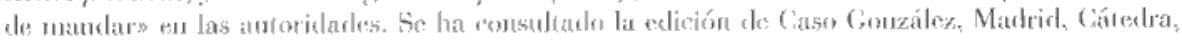
190) p. pítr. $11 \%$.

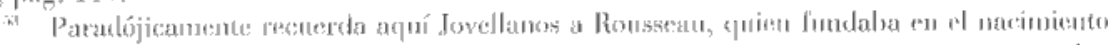

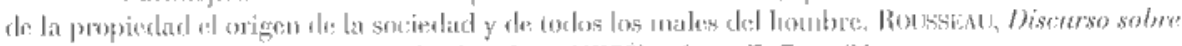

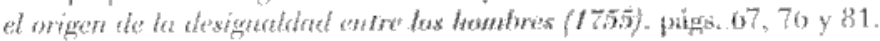

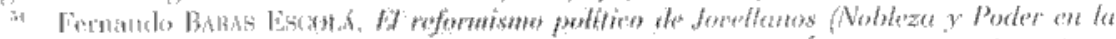

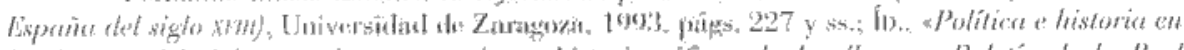

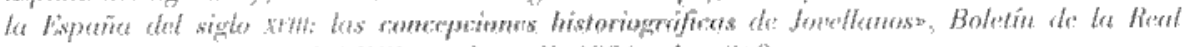

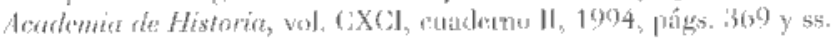

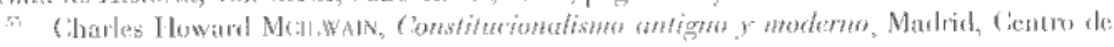
Esturlios Comstiucionales, 14091 pág. 45. 


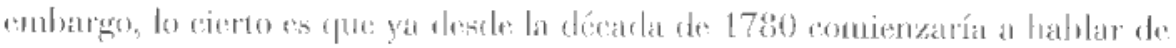

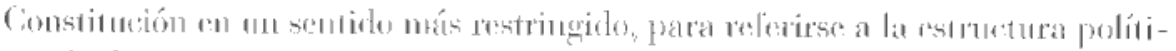

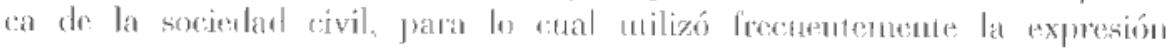

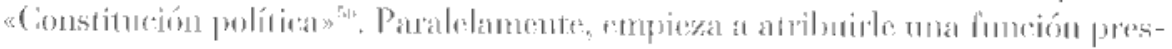

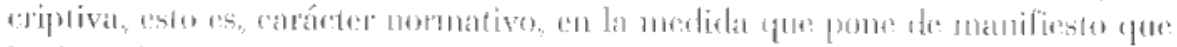

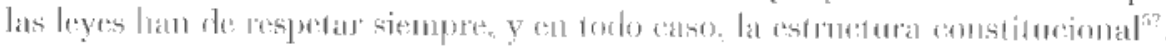

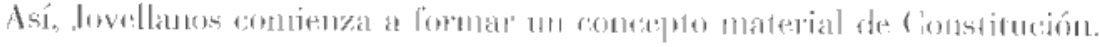

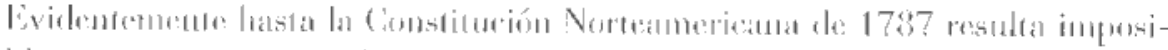

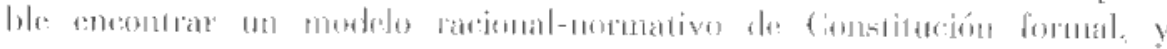

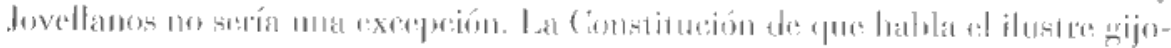

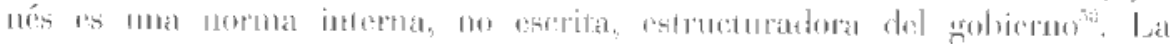

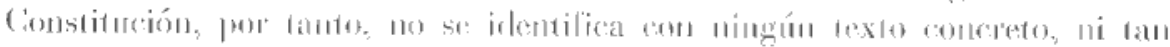

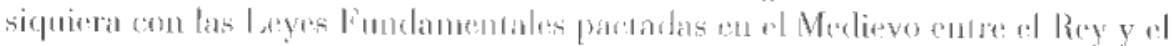

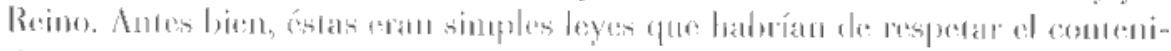

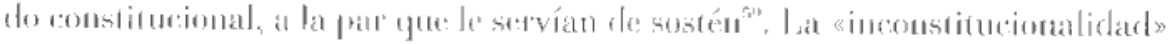

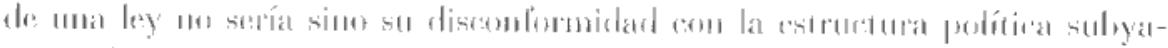
rente al bistarlon.

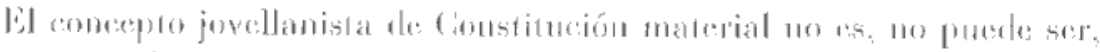

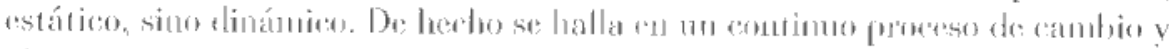

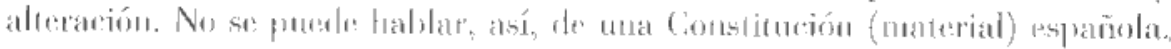

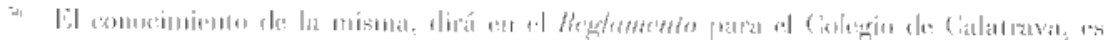

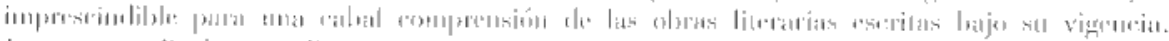

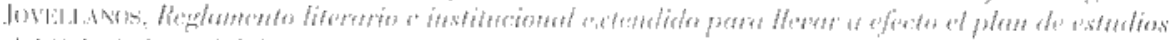

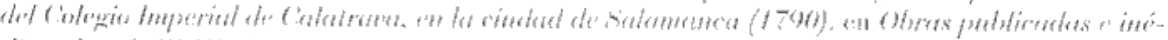

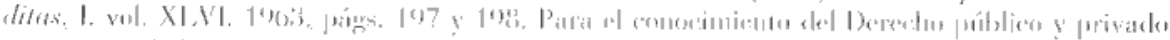

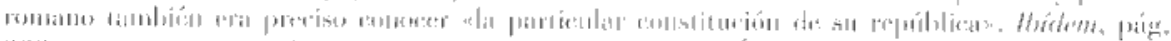

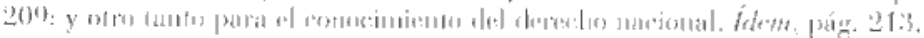

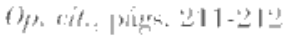

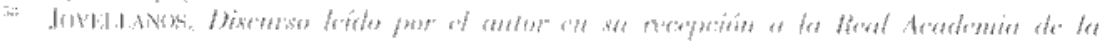

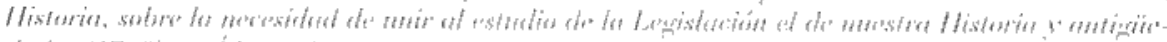

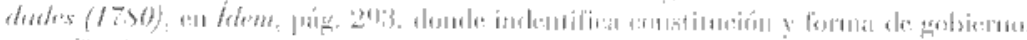

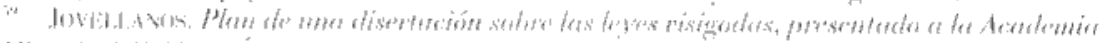

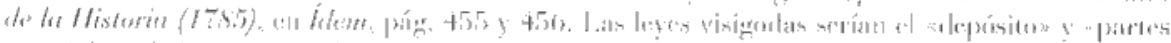

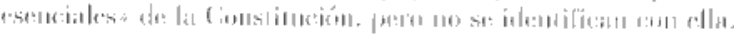

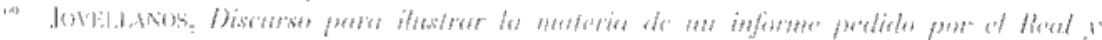

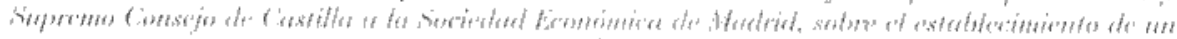

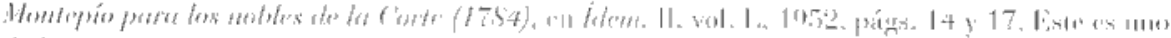

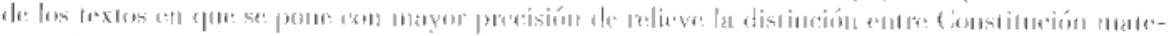

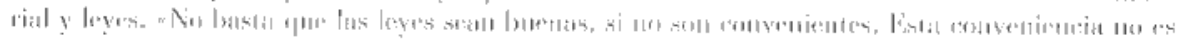

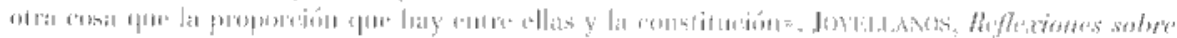

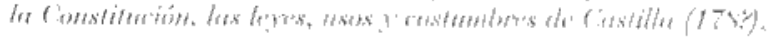


puesto que existe una gran diversidad espacio-temporal de Cionstituciones ${ }^{\text {i.l. }}$ : "Por ventura la Constitución, los usos y costumbres de la Nación que vivía bajo el gobiemo de los visigodos jeran los mismos que en el tiempo del conde Don Sancho, cuando se hicieron los primeros fueros de Castilla? ?Que en el siglo Xu, en que se formaron las Leyes Alfonsinas y se publicó el Fuero Real? ¿Que en los reinados sucesivos en que se promulgaron todas las leyes contenidas en la Recopilación de Castilla? ¿Quién, pues, podrá entender estas leyes, sin conocer las époeas en que lueron formadas?" 02 .

Es en cl Discurso de recepción a la Real Academia de la Historia donde aflora esta jdea con mayor intensidad, aunque no se trata, ni nucho menos, del ruico docunento que la recoge. En el texto citado, partiendo de la concepción de la Constimeión como norma estructuradora del Estado diferenciaha diversas Constituciones que se habóar ido sucediendo a través del tiempo.

I a primera cionstitución sería la visigoda, caracterizada por la reunión a iniciativa del rey de Concilios o Cortes y que Jovellanos deseribe con palabras de admiracióm; sin ducla, el mito de los visigodos alcanzaba también al asturiano, a la par que pone de maniliesto una de sus principales características: el historicismo deformadory que luego utilizarán con insistencia los liberales doceañistas. Esta Cionstitución habría sufrido una "revolución", primero con el ascenso al poder temporal del clero, a partir de los Decreios de Recaredo, y después con la invasión árabe. De aquí se extrae que la legrislación nacional no se identifica con la Constitución material, pero pucde conllevar su alteración, del mismo modo que lo hacen los hechos.

La Reconquista iniciaba una nueva voluntad restauradora de la Cionstitución Visigoda, pero habría resultado imposible aute la sinuación bélirat. Antes hien, el «ser" condiciona el «deber ser", surgiendo una Constitución muy diferente de la amigua y que se caracterizaha por el incremento del poder mobiliario (auténtico sostén de la guerra) y la concesión de fueros particulares

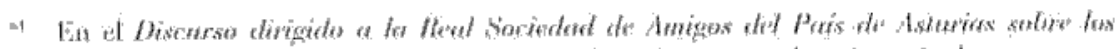

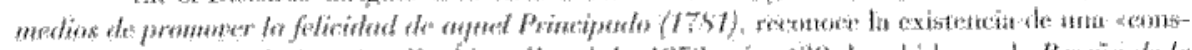

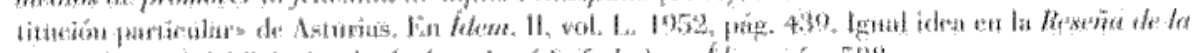

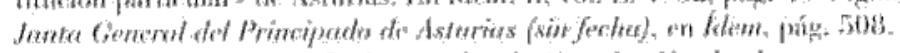

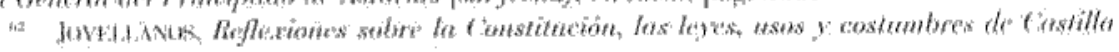
(17S?), pús. 0 .

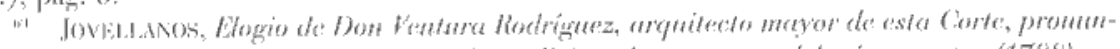

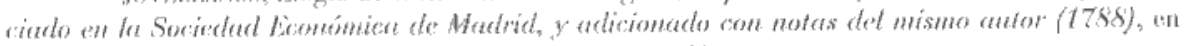

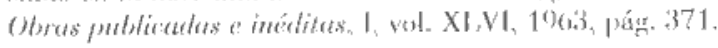


a los municipios. Ein definitiva, se producía una siluación de privilegios particulares, de clase o de burgos, que generaban una dispersion deI poder que se manifiestaba en una Cionstixución con patentes defectos: un monarca débil y. «sobre vodos, un pueblo que no era libre, ahogado por la nohleza a quien ha de mantener. La legislación resultante aparecít, como la propia Constitución, varilante y heterogéne: ${ }^{\mathrm{th}}$.

Una muva Constionsión suregiría a partir, mevamente, de un cambio en la

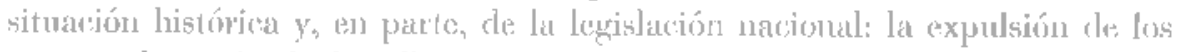
moros y la unión de Castilla supondría la decarlenciz de las clases altas y la concentración del poder regiu, a la par gue el peblo recuperaría su libertart mediante la convocatoria fiecuente de Cortes ${ }^{6.7}$. A vllo habría contribuido tanubién, ronmo se ha dioho, 1 cambio legislarivo: la armonización de la hegislación

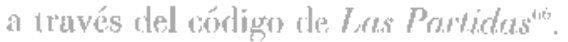

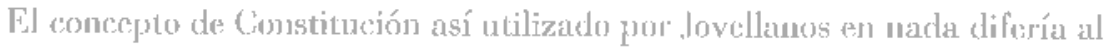
de historiadores como Robertsum. Fsice autor al analizar la historia española

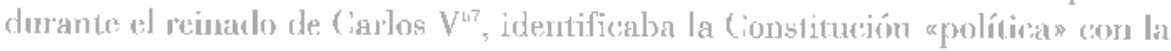

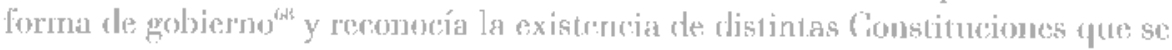
habian surediclo durante la historia de la nación española: primero la Constitución fooda, que se vería sustituida a raíz de la ocupación musulunana y posterior

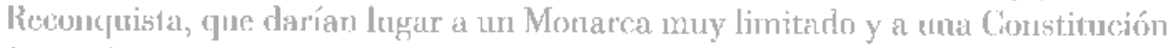

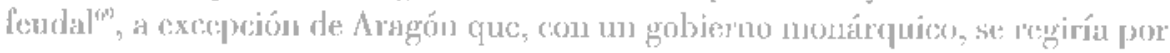
máximas republicanas. Finalnuente, con los Reyes Cintólios surgiria una mureva Cionstitución caracterizada jos la midad nacional y el incremento de poder

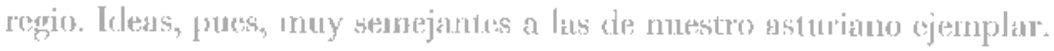

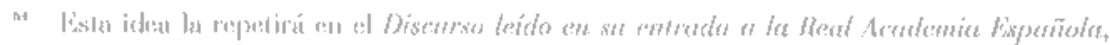

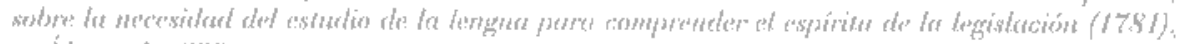

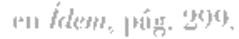

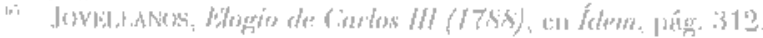

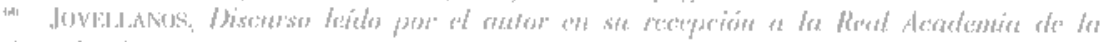

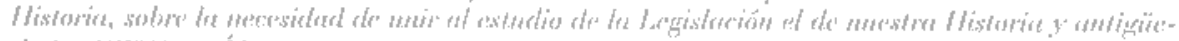

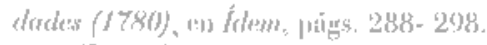

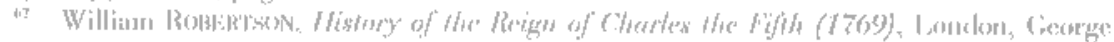
Roullet|gre \& (i) , 1857.

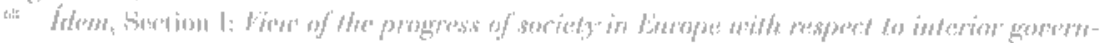

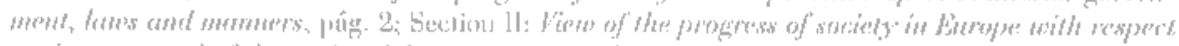

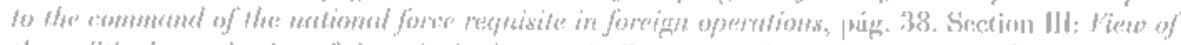

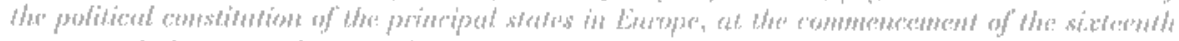
contutry, péssion, r'sperciahlmente príg. 55.5.

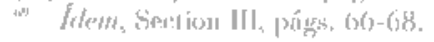


A mediarlos de la década de: los noventa y, principalmente, a partir de 1800, Jovellanos cambia su concepto de Comstitución. En esta alteración habrán de influir, necesariamente, los primeros experimentos de Cionstiuciones normativas formales: la Constucueión Norteamericana de: 1787 y la Francesa de 1791. Jovellanos se liallaba al tanto de ambas y de: los procesos que habían dado lugar a las mismas. Sin embargo, su actitud fue mory diferente en uno y otro caso: respecto a Estados Inidos se mosi ró inicialmente receloso por la inde:pendencia de las colonias ${ }^{20}$, pero acabó por admirar el resulado de la emancipación norteamericana: la Consti1ución de 1787, un rexto que, recuérdese, recogía los postulatos de: Montesquier, a quien dovellanos respelaba polumdanen1e. A trivés de este documento, el pueblo norteamericano, el segundo pucblo en que se había dividido la nación inglesa, caminaba ucom pasos de gigante: al mismo engrandecimiento y a los mismos bieness que la Gran Bredaña . Fin el caso de Francia su actiud no fue, en principio, de oposicion alperia, sino de: expectativa”. Tan sólo con el ascenso del Régimen del Terror se produce un rechazo sin matices a la Revolución. En ambos casos, como se ve claramente, lovellawos se opone a todo acontecimiento que suronga lucha y subversión.

Ahora bien, el ilustre grijoues no se adseribirá al procedimiento mediante el cual surgicron estas Comstiuciomes, esto es, rechaza ol origen de la Comstitución a través de un proceso constituyente. Frente a él, Jovellamos propone la vigencia de mon Constibución histórica, inalterable en determinados aspretos y en ouros susceptible de reforma, pero numea de ruptura ${ }^{7 *}$ \& aquí

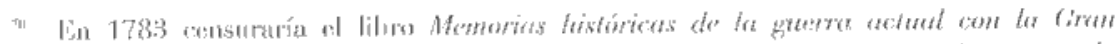

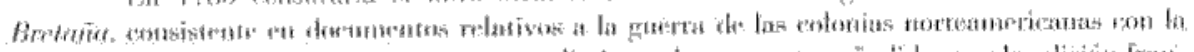

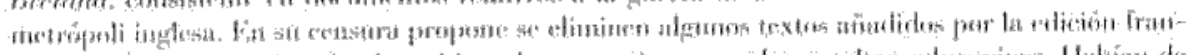

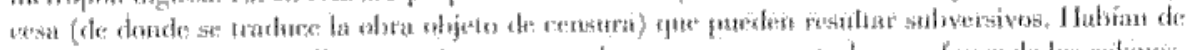

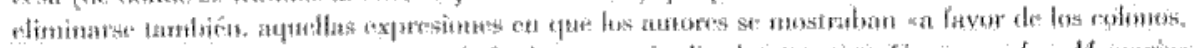

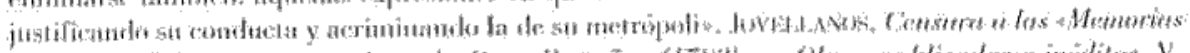

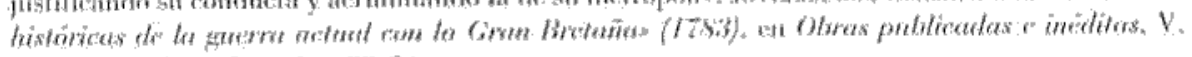

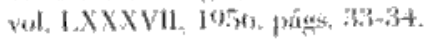

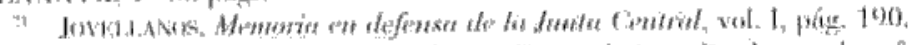

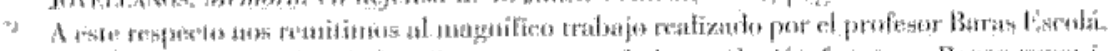

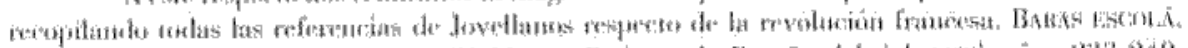

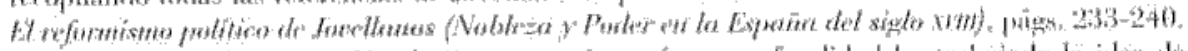

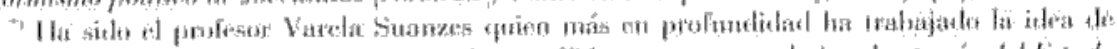

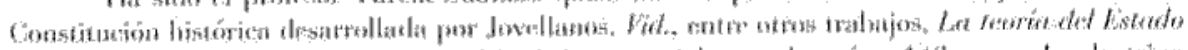

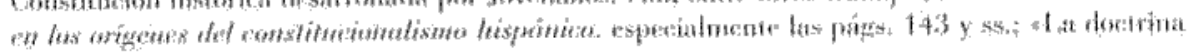


notaré que oigo hablar mucho de hacer en las mismas Cortes una nueva Constitución y aun de ejecutarla, y en esto sí que, a mi juicio, habría mucho inconveniente y peligro. ¿Por ventura no tiene España su Constitución? Tiénela sin duda; porque jqué otra cosa es una constitución que el objeto de leyes fundamentales, que fijan los derechos del Sobevano y de los súbditos, y los medios saludables de preservar unos y otros? ¿Y quién duda que España tiene estas leyes y las conoce? ¿Hay algunas que el despotismo haya atacado y destruido? Restablézcanse. ¿Falta alguma nedida saludable para asegurar la obscrvancia de todas? Establézoases?t.

Si hasta el momento Jovellanos había hecho referencia a ma especie de *Constitución internas, no identificada con las leyes fundamentales altomedievales, a partir de nucdiados de los años 90 eleva estas úlimas leyes al rango de Constitución. Por consiguiente, la Constitución empieza a identificarsc con textos rormalivos concretos. Sin embargo, Jovellaros no abandona totalmente su antigna concepción constitucional y no lo hace en un doble sentido. Por una barte, porque: la constitución sigue siende para ála que decrmina la forma de geblerno y, por olra, porque sigue teniendo un caráder progresivo y evolutivo. Vé́noslo.

Lri esce nucvo concepto de lex legam Jovellanos sólo parex atribuir rango monstibcional a aquellos textos medievales que contienen los principios estrucluradores del listále y determinan la lerma de gobierno ${ }^{7 \%}$. Ein este momento, la Constitución es, para Jovellanos, la nomma conjunto de normas a vavés de las cuales la sociedad civil determina la forma de gobieno y traspasa el cjercicio de la soberanía, mencedida cono direceión de la acción común ( «soberaniáa políi (a) $\left.{ }^{7 t}\right)$. Por consiguiente, lo que antes cra soporte legal de la Constiución, acaba

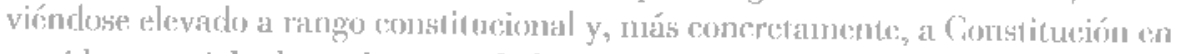
sentido material, al sta el conterido lo refinitorio de su calificación juridica.

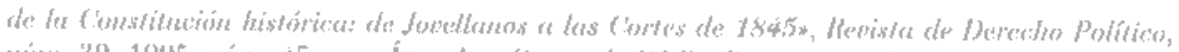

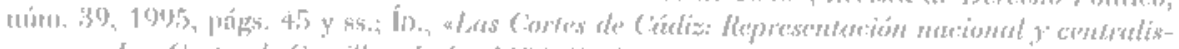

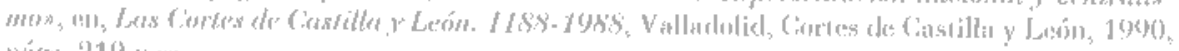
pings. 219 y se.

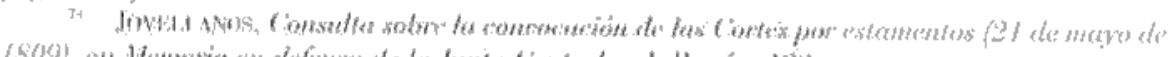

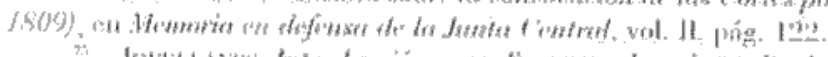

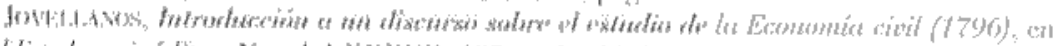

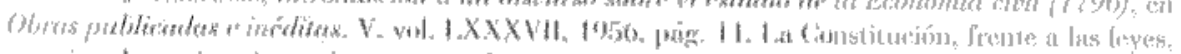

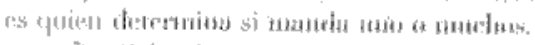

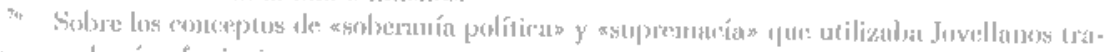
caremos en el chigrate sigutenut. 
Ahora bien, la Constitución, como más adelante veremos, no habría permanecido siempre inahterada. Luego, para determinar la uesencia» de la Constitución española había que hallar cuál era la constante que había perdurado a lo largo de sus sucesivas modificaciones. Y Jovellanos halla la respues1a: la esencia de la Constiución shistórica» residía en que España siempre había sido monárquica, esto es, d Rey siempre había sido el «soberano políticos $^{77}$. Por otra parte, el pueblo siempre tuvo ocasión de ser llamado a Ciortes, y sólo una indescable práctica habría terminado por ahogar tan saludable cosnumbre. Ahora bien, si hay que ser congruentes con el pensamiento jovellanista, en tanto el carácter monárquico del gubierno es «lijados en la Cionstitución histórica, el llamamiento a Cortes es meramente *reconocidos por ella. por lo cual bien podría decirse que los gobiernos sucesivos descle la época de los Reyes Católicos habían sido, en cierta medida, kimeonstitucionales».

En todo caso, esta asencia» de la Constitucióm histórica representa lo ifue podría llamarse smínimo indisponible»; un contenido inmutable ${ }^{7: t}$ que debía respetarse en tanto el Monarea designado cumpliese con los términos consiituciomales ${ }^{7 \%}$. Lste mínimo integra el elcmento estático de la Constitución, dilerencia, ésta, con respecto a su antigua idea de Constitución material que no se hallaba sujeta a ningún tipo de anclaje.

Pero, más allá de este "inínimo», la Constitución se hallaba en progreso, segumdo demento, éste, que conecta con la primigenia idea de Constitución material. En efecto, la Cionstiturión se había visto sujeta a cambios, hasla el punto de que ya casi ni se conocía: "T Tencmos por ventura en España una Constitución? Si usted me dice que só, jómo es que no la estudiamos, que no la conocemos? Si me dice que no, siendo constante que la tuvimos en algún tienpo es preciso decir que la homos perdiclos. ¿Y dónde buscarla? aen muestros viejos códigos, en nuestras aniiguas crónicas, en nuestros despreciados manuscritos y en nuestros archivos polvorientos" ". Este lexto pone de manifiesto la

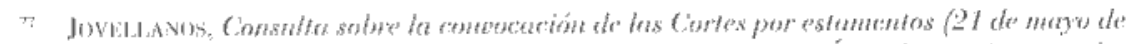

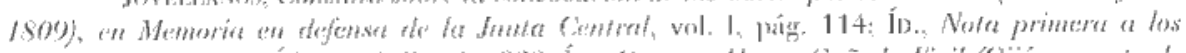

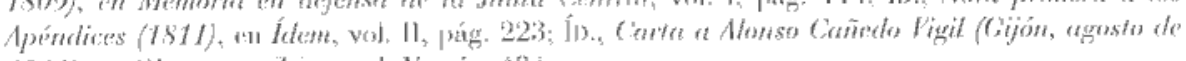

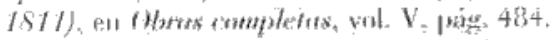

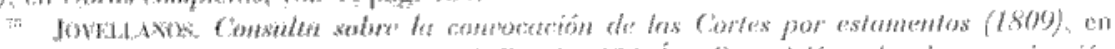

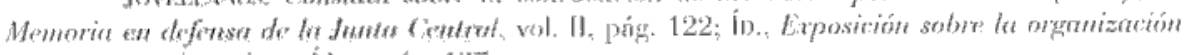

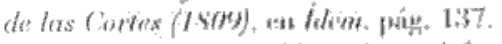

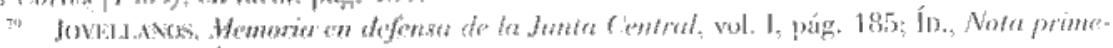

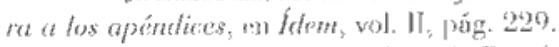

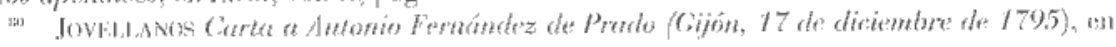
Obrus completers, vol, III, páges. 179)-180. 
superación del antiguo concepto constitucional gue esgrimía Jovellanos: si todavía entendiera la Constitución womo material, no cabría plantearse su existencia o no, puesto rue cista, en cuanto estructura socio-potítica pucde variar, pero en todo caso siempre existe. Por otre parte, los hrehos ya no son delemminantes de la Constitución. sino que ésta se contiene en las leyes medievales.

Pocos años después insiste en lu misnné idea: « jo teme araso que colos doeumentos expongan uma ronstifución que no existe? Pero jno harían vel

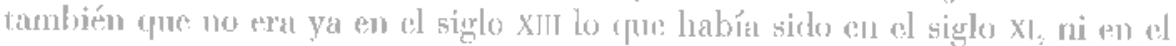

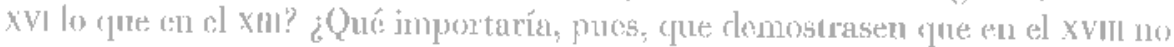
se pareos a ninguna de las antiguas épocess? Y jqué puelilo no ha mejorado o por lo menos variado y alterado su consutución y sus leyes? Y pues que la situación polí1 ica de todos es variable, z̧ouín seré ol que pretenda estabilidad cuando la restabilidad misma fuera m mal gravísimo?" "

De esta lorman, puede decirse que la Comstitución jovallavista se costruetura at dos niveles: uno nónimo, esiático, y otro exterior, dinámieo. Puesto que la Cimmitución valíd, es susceptible de mejora, es perfectible, lo rual encaja perfoctamente com la idea de progreso, tare ilustracla y, por ende, tan pupia de lovellanos. Se distancia, así, de las tesis tradicionalistes, para quienes la listonia,

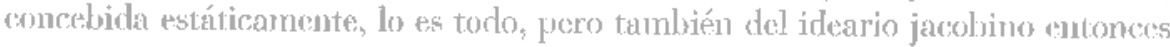
imperante entre Ins rlipulados gaditanos. Y es rue el asturiano no reconocía (s)

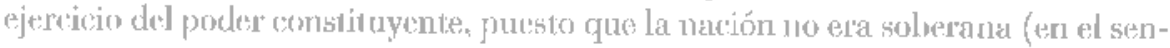
tido que afirmaba Sieycs), sirno suprema, por lo que no podía crear ex move mat Constitución, sino que poseíc una reserva de poder cque le permitía alterarla o relormarla: "I áa Comstitución es siempre la efectiva, la histórica-alirmaba en sus Diarios-, lit que no en turbtalentas Asamb]exs ni en un día de asonada, sino con largas edirdos fue lonta y trabajosameste fducando la conciencia nacional, ron el

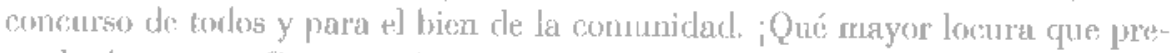
wender hater una Comstitución romo quien hace un drana o una novela! "*2.

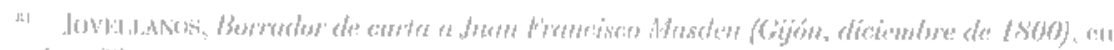
hloh, páng. (ont)

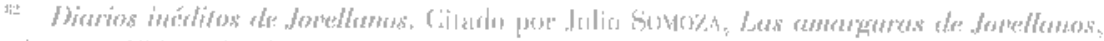

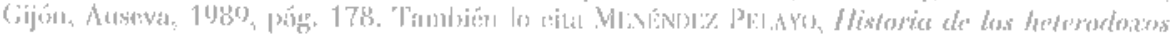

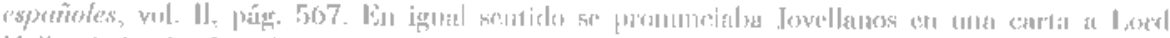

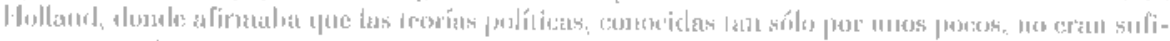

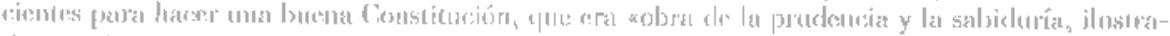

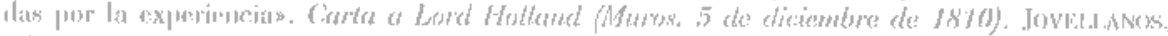

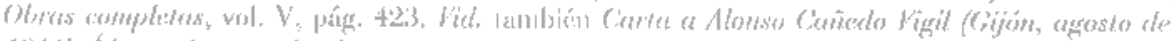

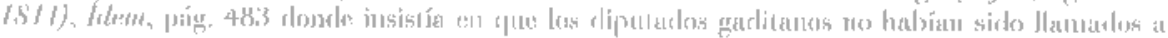

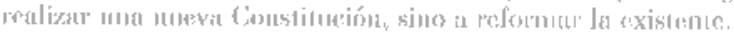


Si se reconocía a la Nación el poder constituyente, se conseguía una Constitución precaria y disponilule, jacaso estaba pensando en la sucesión de Constituciones que había vivido Francia?: «Si ésta [la Nación] puede destruir la Constitución que renía jurada, jno podrá otra legislatura destruir mañana la que jurare hoy? Y entonces ¿qué estabilidad tendría la Constitución? $x^{\text {tas. De }}$ alí su postura, afín a su moderantismo: "Nadie más inclinado a restaurar y afirmar y mejorar; nadie más tímido en alterar y renovar (...) Desconfío mucho de las teorías politicas y más de las abstractas. Creo que toda nación tiene su carácter; que éste es el resultado de sus antiguas instituciones ${ }^{i 3 t}$.

En este sentido, Jovellanos se acerca emormemente a las teorias de llume y Ednumd Burke. Por lo que respecta al primero, en su Historia de Inglaterra incluía constantes reforencias a la Constioción inglesa, concebida como una Constiución histórica, por la cual entendía «aquella que prevaleció antes del establecimiento de nuestro plan actual de libertad ${ }^{5,5}$, esto es, la cionstitución subsistente hasta la Gloriosa Revolución. Ina Constitución que, sin embargo. como succolía en el pensamiento jovellanista, no tenía un carácter absolutamente estático: "The english constitution, like all others, has been in a state of continual fluctuation»" El aprecio por la bibertad del pueblo ingrés y por la antigüedad generaba la pasión por su Constitución limitada ${ }^{4 ?}$, lo que en parte. justificaba el rechazo generado por el Instrtment of Government que tratara de introdıcir Oliver Ciromwell; un documento que, redactado lan sólo en cuaro días, pretendía ser la regla de gobieno de tres reinos, como diría sarcásticamente el filósofo escocés:

Por su parte, Burke afirmaría, com sn hrillante estilo, fout "no se puede estimar la pérdida que se sufre cuando las antiguas opiniones y reglas de vida se hacen desaparecer. Desde ese momento no tenemos brújula que nos gobierne, ni podemos saber a qué puerto nos dirigimos ". Como sostendría también

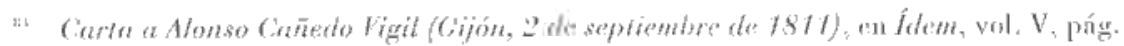
486.

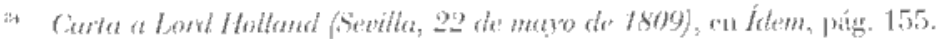

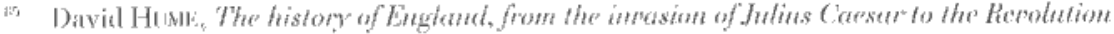

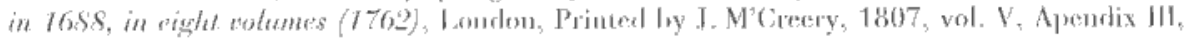
príg. 452 .

this Hident.

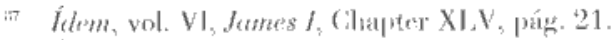

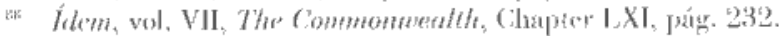

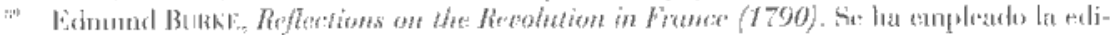

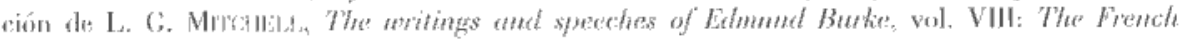

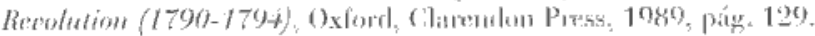


Jovellanos, mantener el edilicio histórico no suponía rechazar las mejoras posibles: «el pueblo de Inglaterra sabe bien que la idea de herencia proporciona un principio seguro de conservación y un seguro principio de transmisión, sin excluir con ello un principio de mejorà ". En esta mejora, añadía Burke siguendo a Humes, «haría la reparación lo más parecirto posible al estilo del erificio (...) Añadanns si se quiere, pero conservenos lo que nos han dejados".

Jovellanos conoría estas opiniones, puesto que los autores citados cayeron wa la órbita de su avidez lectora". Como también lo hicioron los disturses que en el seno de la Cámara de los Commes realizaton Fox, Pitt y Sheridan ${ }^{4: 3}$. El primero de ellos, representante del sector radical whig contemplaba una idea de Constitución semejante a la que Jovellanos defendiera en nuestra nación: desaprohando las opiniomes de guienes afimaban que Inglaterra carecía de Constitución, al no constar ésta en un documento único, Fox afirmaha que shis Jowe of the constitution was to the constitution on its old form, which had subsisted by constant reformation, and was such a nature, that if it was not improving, it was in a state of deray. "l. Unas ideas que Jovellanos no sólo conoceria por sus lecturas, sino taunbién al través de sus contactos con l orel l lolland, a la sazón también cliputado whig y sobrino de Fox. Por ello, no es de extrañiar que Holland pusiose de numifiesto en su correspondendencia con el gijonés que en Inglaterra habís *muchos, muchísimos que piensan cumu [errsaba $\mathrm{Vd}$. ${ }^{25}$.

(4) hem, prógs. 83-84

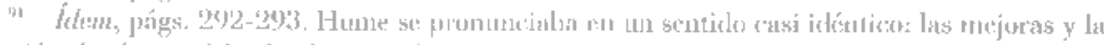

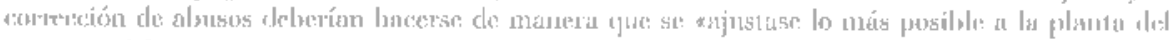

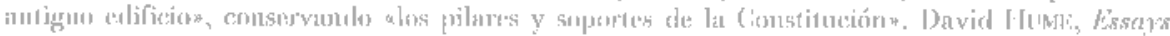

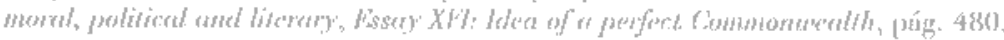

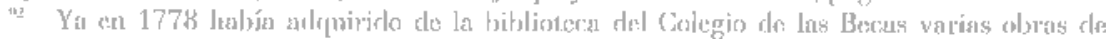

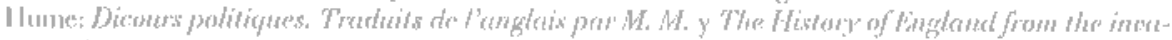

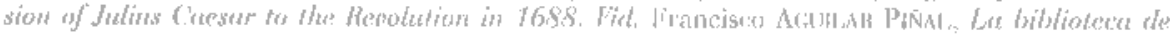

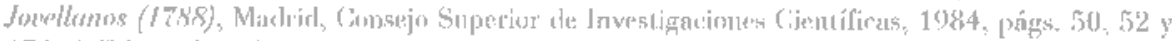

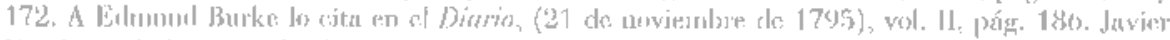

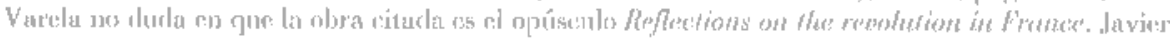

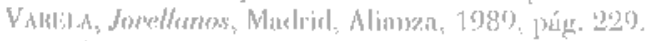

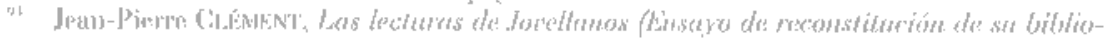
lecri), Ovirede, [.D.E.A., 1080, pán. 198.

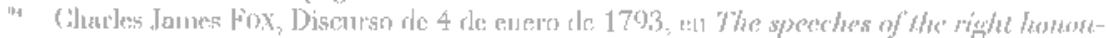

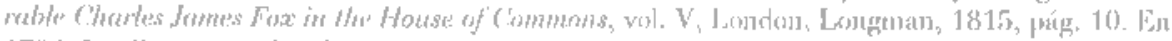

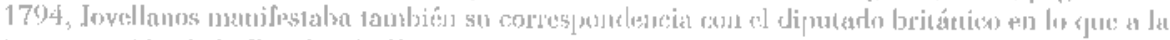

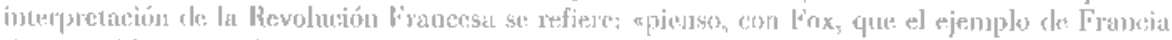

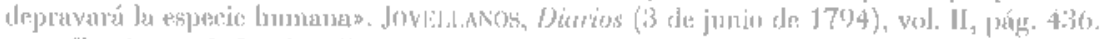

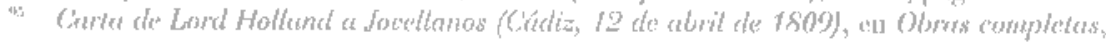
vol. V. pág. 104. 
La Cionstitución que contemplaba Jovellanos era pues, perfectible en su mayor parte; se trata de una "Constiución progresiva", susceptible de mejora". Esta sería fruto de la razón y de las aportaciones de la experiencia exiranjera. Nuevamente el mérodo cartesiano y el empirismo de Bacon se mixturan. Existían elementos constitucionales claramente idóneos para cualquier sociedad; elementos que podían incluso contribuir a la mejora social. En concreto, el gijonés consideraba que el modelo de Cionstitución Mixta y equilibrada consdiúa un ideal descable. A ello conducía la razón, pero también la expericucia, concredanente la inglesa, que ron ereces había demostraclo la celsitud de tal sistema. Este punto lleva a replantearse la propia imagen del Jovellanos tradicionalista y alerrarto a las costumbres castizas y a las instiuciones genuinamente españolas. Si la Constinción había de estar en consonancia con la sociedad, no resulta menos cierto (pue, como se ha visto al tratur la Teoría del Estado, las sociodades no eran sino realizaciones particularizadas de la tendencia a la miversalidad". Por danto esa muversalidad del hombre está por encima de las particularidades: laty moclelos universalmente válidos. Por otra parte, recuérdese que Jovellanos partía de lo timilado del conocimento humano sin la asociación de sus semejantes, lo que conformaba una postura clara mente receptiva a las aportaciones exógenas: la historia, decía, uacredia que los hombres se cultivaron al paso que se comocieron y reunicrons".

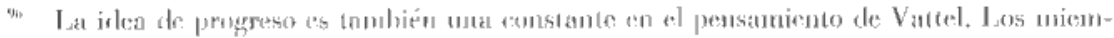

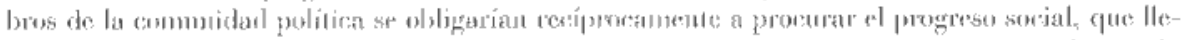

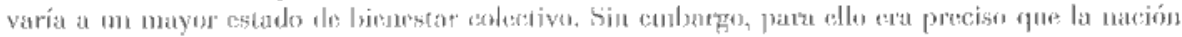

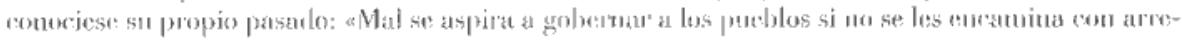

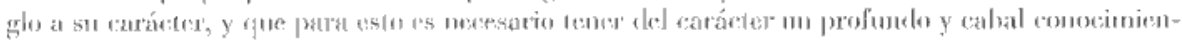

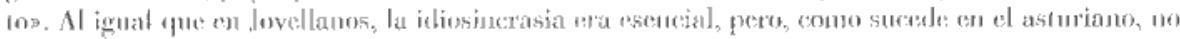

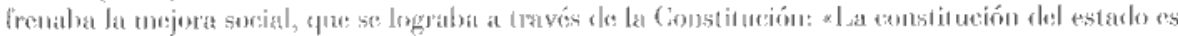

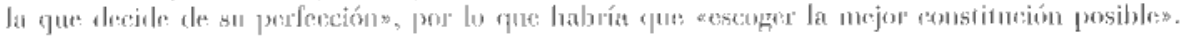

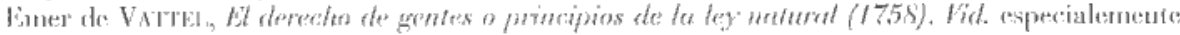

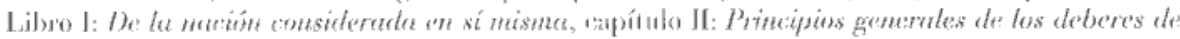

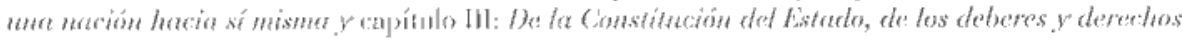

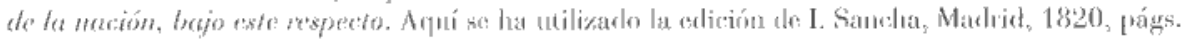
35 y 84.

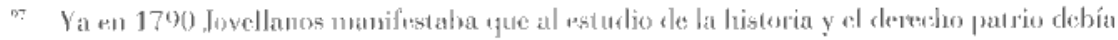

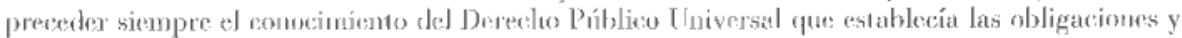

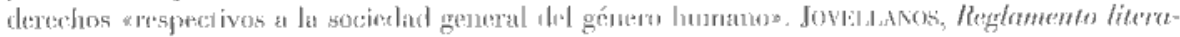

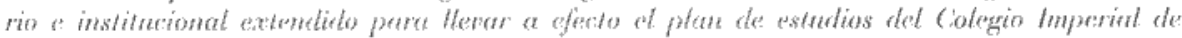

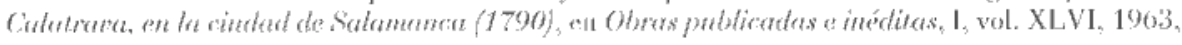
pín. 208.

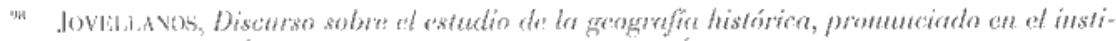

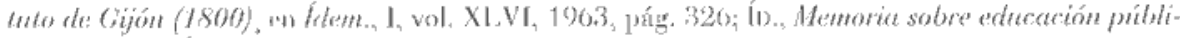

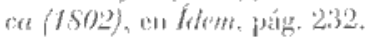


Sin embargo, Jovellanos asmme una idea de progreso «gradual», escalonado, en coherencia con su visión histórica, que demostraba más un progreso

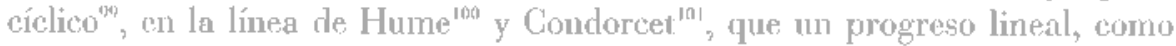
pretendía Turgot ${ }^{10 z}$. Esta graduación imponía necesariamente límites a los ensayos constitucionales que pretendiesen introducirse en nuestro suelo. «Es, pues, necesario - le comentaba a Hardings- llevar el progreso por sus grados»; cada nación debía buscar aquella forma de gobierno que estuviese «nás cerca de su estado, para pasar de clla a otra mejons" "it.

Cada Constitución era, pues, apropiada para nna sociedad: «Por sabia, jor buena que so suponga [la Constitución] no se debe negar que pueda ser perfeccionada, puesto que la perfección de la Constitución debe resultar de su conveniencia con la extensión y naturaleza del erritorio que ocupa cada pueblo (...) todas las relaciones de la política tienen una esfera señalada y ciremuscrita por los límites de la sociedad ${ }^{12+}$; las mejoras presihles debían estar en consonancia con rel estado noral de las natio-

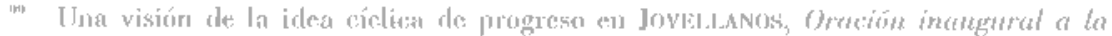

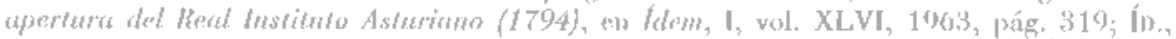

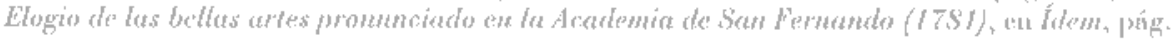

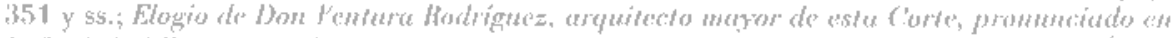

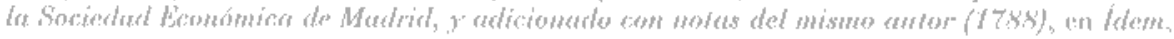
págs. 379 y ss.

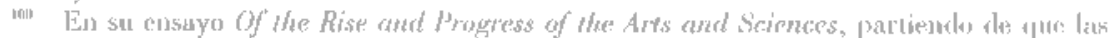

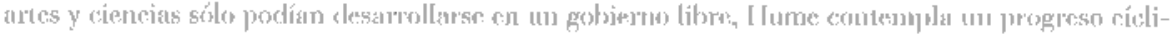

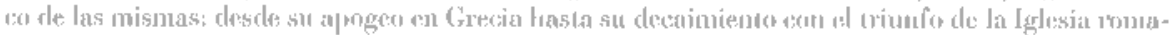

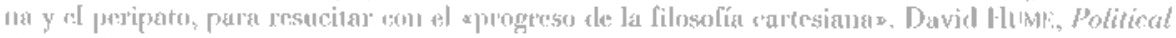

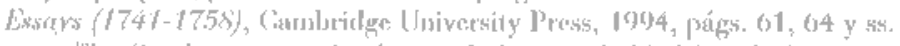

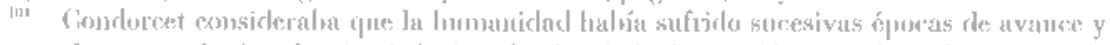

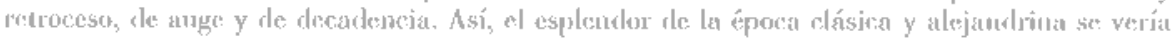

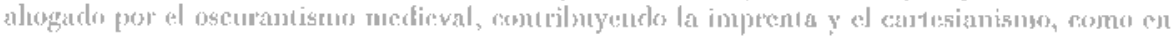

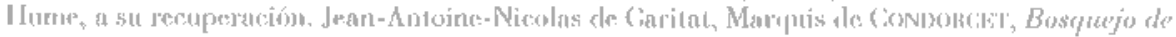

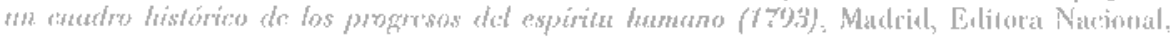
19800, pissim.

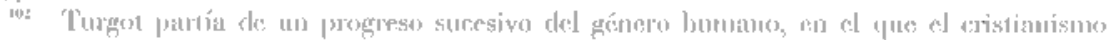

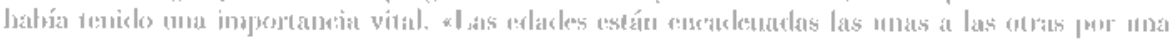

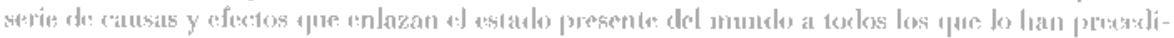

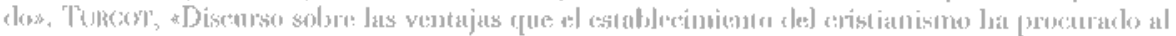

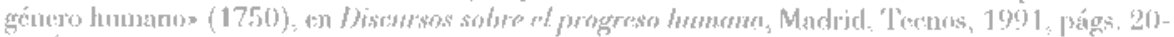

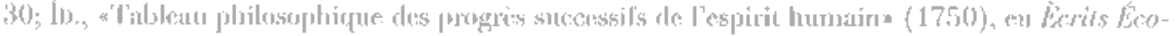
nomigues, prig. 41 .

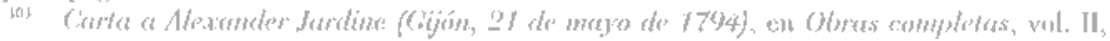
jág, gín,

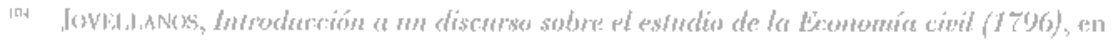

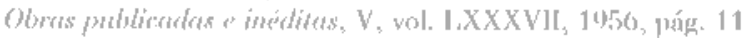


nes» ${ }^{105}$. En la Memoria sobre educación pública, Jovellanos afimaria que toda forma de gobierno era perfectible, pero debía hacerse de acuerdo con la forma de la sociedad civil"tí. Sin embargo, como veremos en el epígrafe siguiente, la Constitución inglesa era perfectamente acorde con nuestra sociedad y, por tanto, aplicable en España.

\section{FORMA DE GOBIERNO}

Elección de la forma de gobiemo

Constituida la sociedad civil y el Estado a través de la renuncia parcial de derechos individuales (como se vio en el primer epígrafe), el siguiente paso consistia en determinar la forma de gobierno adecuada para dirigir esa socicdad. Cuál era esta forma de gobierno ideal será una cuestión que se abordará en el último epígrafe, por lo que ahora habrá que centrarse tan sólo en su proeeso formativo.

El momento selectivo de la forma de gobierno resultaba posterior al pacto social y tenía lugar "ya por la constitución del Estado, ya por la legislación" ${ }^{107}$. Esto es, la Constiución era la que determinaba el sujeto o sujetos que iban a ejercer el poder público.

Fs en esta determinación constitucional de la distribución de la autoridad pública donde ha de ubicarse la famosa Nota primera a los Apéndices de la Memoria en defenst de fa Junta Central, en la que Jovellanos no trata del origen de la sociedad y a listado, sino del nomento posterior de selección ope constitutione de la forma de gohierno.

Antes de analizar este texto es preciso matizar su ubicación temporal: a través de la Nola primere Jovellanos trata de impugnar la idea de soberana nacional y la forma de gobierno cuasi-asamblearia que defendian los liberales gaditanos. () inás bien, lrata de reinterpretar cosa idea de soberanía nacional, cambiando su rumbo para cvitar que se imponga un réginen que desemboque

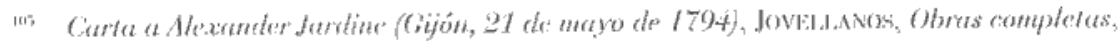

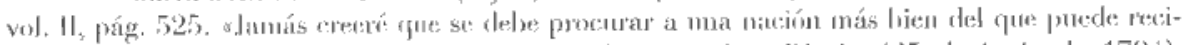

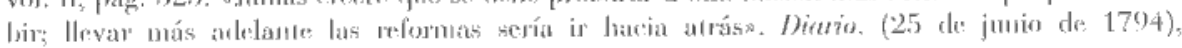
Jovila ANos, Diarios, vol. J, paig. 446.

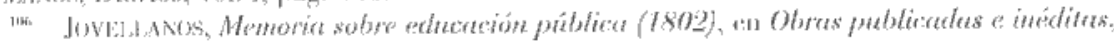
1, vol. XLV1, 1963. pág. 255.

in? folme páng. 250. 
en un émulo de la Cionvención fruncesa ${ }^{\text {na }}$. Pero, por otra parte, esta Nofe matizá, explica y, por qué no decirlo, leorienta el documento más conservador que: produjo la pluma de Jovellanos: la Consulta sobre la convocación de las Cortes por estamentos; rexto coyuntural, como habrá ocasión de comprobar en su momento, y alcjado de las teorías que el gijonés defendería en la Junta cientral.

En la Nota, el polígrafo asturiano ponít de manifiesto la polisemia del térnino "soberunia». Tomada en un sentido «originario», sería el pocler absolu-

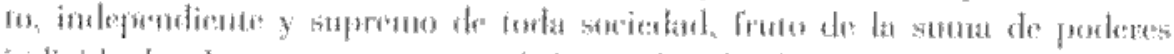

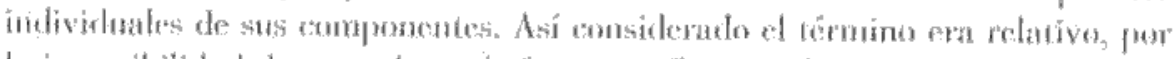

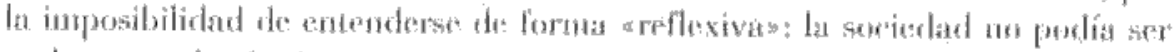

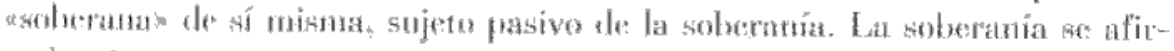

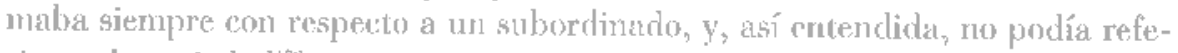
rirse a la socicdading

Por esta razón, Jovellanos rescrvaba el concepto de sohcranía para la

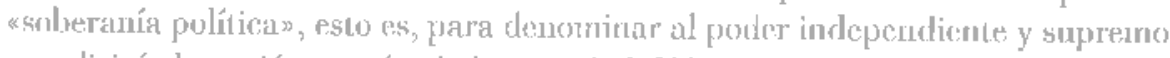
flue dirigía la acción común de la sescicedad. Nótesc que omilia al arljelivo «corisillarion, con gran coherentia, puesto yue esla autoriflarl se fundamentaba on una norma, la Constiución, de modo que no sería originaria, sino "polílica»y derivada. El problema de la soheranía cin este texis de Jovellanos no es escencialunerite un problema de 'Teoría del Esiado, sino un prohlema constitucional.

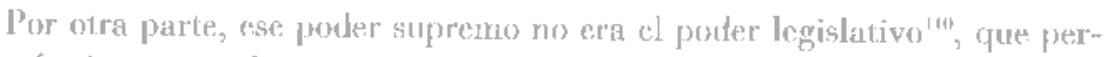
mancóa siempro en la comunidad, como veremo, sino el poder ejecurivo, o

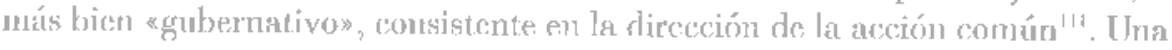
ling. 48,3,

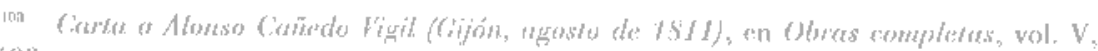

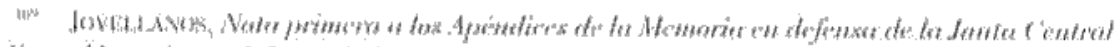

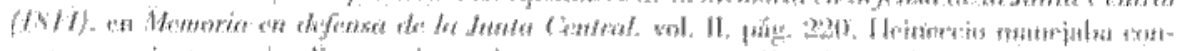

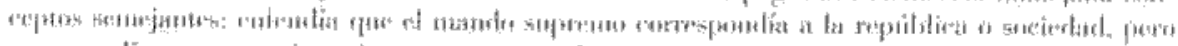

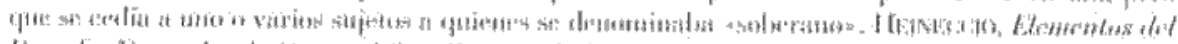

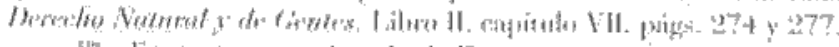

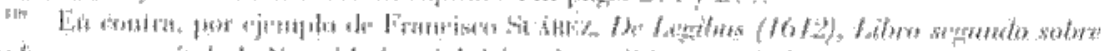

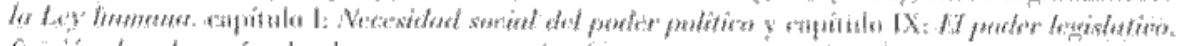

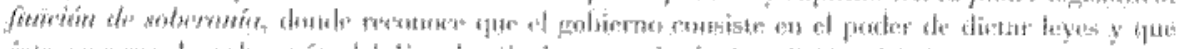

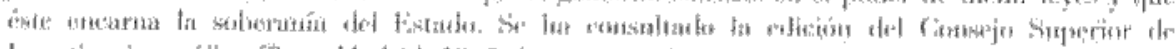

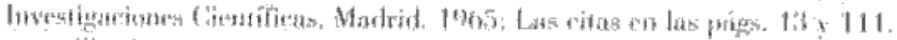

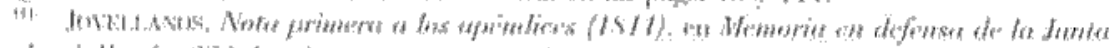

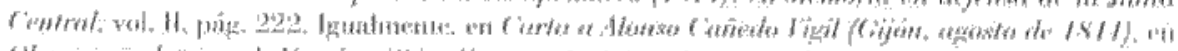

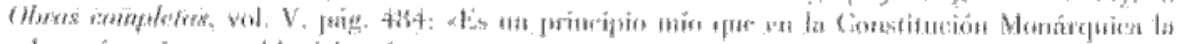

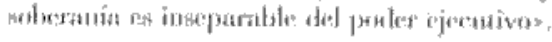


idea rue lo separa no sólo de las teorías liberales, sino también de las escolásticas, y lo mantiene aferrado al iusnatmalismo racionalista, concretanuente a Burlamaqui, para quien la soleranía comsistía, precisamente, en la dirección de la comunidad ${ }^{\prime \prime 2}$.

La dereminación de quién ejercería la *soberanía política supunía optur por las distintas formas de gobierno posibles"': se hablatía de democracia, bien cuando la dirección de la acción común la ejerciesen todos o ciertas personas elegidas por todos, bien cuando la commnidad se reservase la potestad legislativa, confiando a uno o varios sujetos reclegibles la dirección de la acción común. Nadie ha parecido percatarse que en este punto Jovellanos está describicndo los regímenes francés, en el primer caso, y morteamericano, en el segundo, para adjetivarlos de «democracias». En fefeto, democracia había sido la francia revolucionaria del 91 (a la que los liberales gaditanos pretenclian imitar), porque la acción común correspondía a la Asamblea elegifa por la Narión (rógimen asambleario), y democracia cra Norteamérica porque, aun cuando la commidad poseía el poder legislativo (Congreso de los Estados (Tnidos), Ja acción común la llevaba a cabo un lefe del Estado electivo.

Pos el contrario, la aristocracia y la monarquía supomían no ya la autodirección de la acción común por la commidad o la mera adelegación» de la misma en un sujeto (Presidente), sino en la alrdicación, en favor ya de varios (arislocracia), ya de uno (monarquía). Abdicación que suponía la renuncia plena de esa dirección política.

Llegados a este punto, Jovellanos introducía un nuevo concepto: la "Supremacía». Si la commidad abdicala de su poder direcivo, ¿qué le quedaba? Pues ciertos deredus originarios, remanemes, irrenunciables, a los que

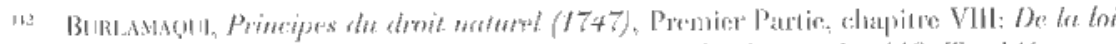

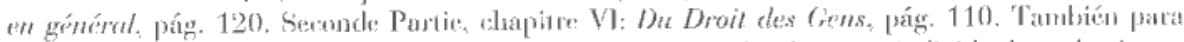

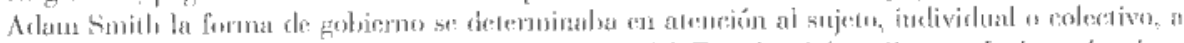

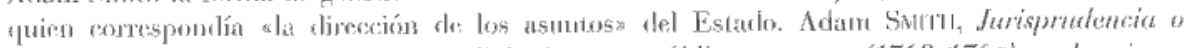

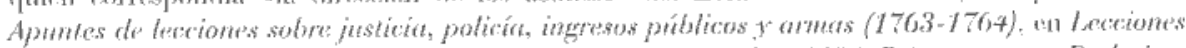

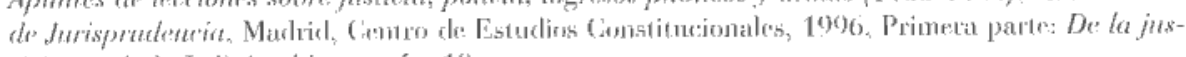
licin, cupímlo I: Del gobierro, príg. 18.

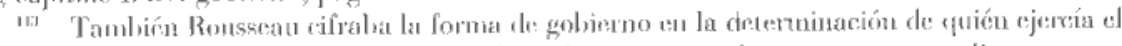

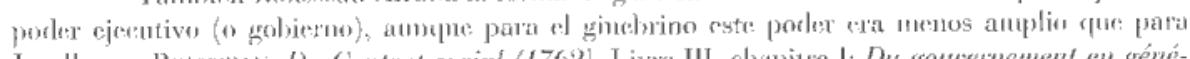

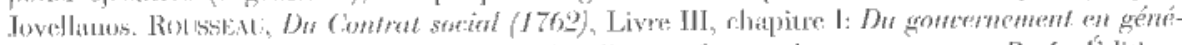

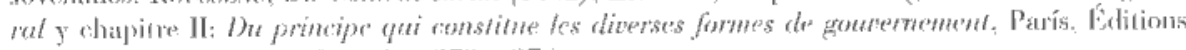
Garnier Froms. 1962, 1900 , patgs. 273 y 276 y ss. 
englobaba dentro del concepto supremacía y que constituían un poder para garantizar la Constitución a través de la cual se había transferido la autoridad pública. El contenido concreto de este poder sería: en primer lugar, el ejercicio de la potestad legislativa por los representantes de los ciudadanos convocados en Cortes; en segundo lugar, la posibilidad de reformar la Constitución y, finalmente, la potestad de ejercor el derecho de resistencia frente al «soberano políticos 114 .

Coherentemente, Jovellanos afirmaba que la suprentacía tenía un carácter originario, puesto que no se fundamentaba en la Constitución (como sucedía con la soberanía política), aunque ésta la reconocía. Precisamente por ello, acababa diciendo Jovellanos que «es indubitable que la supremacía nacional es en su caso más alta y superior a todo cuanto en política se quiera apellidar soberano o supremo ${ }^{11:}$.

Ahora bien, no cabe mentender gue lá construcción de Jovellanos, distinguiendo entre soberanía y supremacía, era inútil, como opinan los profesores Arrola y Ciaso. Para el primero, los interitos jovelinisistas de romper con los postolados gaditanos es fútil, puesto que cl resultado es idéntico ${ }^{16}$. Al entender de Caso, el asturiano no se separaba, deliberademente, tel Decreto de las Cortes de Cádiz de 24 de septiembre de 1810, de forme que las diferencias ontre su doctrina y la allí expuesia son meramente en "algún matiz no signilicativo»" Sin mombaryo, erecmos que Jovelianos fue más sutil de lo que parece, puesto que indenta demostrar que, cuando las Cortes de Cándz hablau de «sobenania nacional», con realidad quieren decir" «sipremacía», esto es, no se refieren a un porder absoluto, incuntestable, que encierea como principal manifestación el cjercicio del poder constituyente, sino a un poder originario, ciertanents, pero residual, que consiste prosisamente en aquellos puntos que son la onseria polílica clel gijonés: reunión de Cortes, reforma y ro ruptura constitucional, rechazo al tilano.

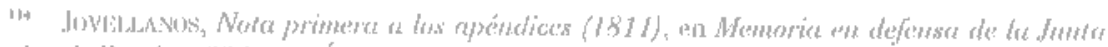

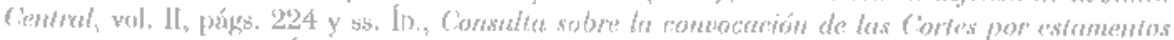
(2) de mayo de 1809$)$. frem, pág. 110.

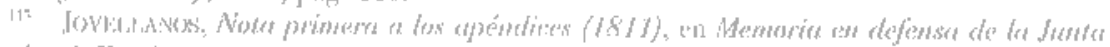
Cemtrel, vol. JI, púg. 227.

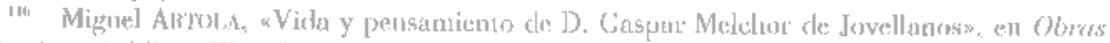
publicadess e inédilas, III, vol. LXXXV, 19,52.

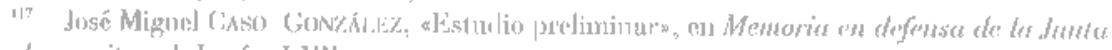

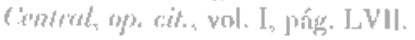




\section{La Monarquía equilibrada}

La Constitución española era, al parecer de Jovellanos, susceptible de reforma y mejora. Se trataba, pues, de deterninar el modelo conforme al cral llevar a cabo el perfeccionamiento de la Constitución. Si el gijonés acudía a las obras nacionales para conocer la esencia de la Constitución española, el «ser». la lectura de las más relevantes publicaciones francesas e inglesas le proporcionaban las ideas del «deber ser», de las mejoras que debían hacerse en la Constitución histórica.

El diputado de la Junta Central rechazó palmarianente el modelo francés impreso en las Constituciones de 1791 y $1793^{113}$, y consideró como ejemplos positivos lanto la Constitución Inglesa como la Norteamericana o la francesa del año III". Estas últimas tienen una nota en común: la esencia de la separación de poderes tal y como había sido trazada por Montesguteu en su interprelación de la Constitución inglesa.

Por consiguiente, de forma directa o indirecta, el sistema de gobierno británico conformaba el cjemplo. En él, el asturiano véa una Constitución equililirada, en la que jumto con una separación rígida de los poderes del Éstado se inclúan una serie de controles mutuos (rhecks and balances) que frenaban la arbitrariedad: así, al Monarca le correspondía el derecho de sancionar las leyes, a las Cortes garantizar su observancia y la de la Constitución y, finalmente, el Parlanento se dividía en dos cámaras, de manera que entre la Cámara Baja, popular, y el Rey, se instauraba und Cámara Alta que, integrada por un cuerpo intermedio aristocrático, actuaba a modo de cámara de reflexión.

Estos elementos cran perfectamente compatibles con la Constitución histórica porque, en parte, ésia ya recogía alguno de cllos: concretamente la división de poderes, que se hallaba de forma combrionaria e imperfecta en nuestra nación ${ }^{1: 2 !}$, lo que la convertía, en la Edad Media, en una «le las mejores de Europa» ${ }^{121}$.

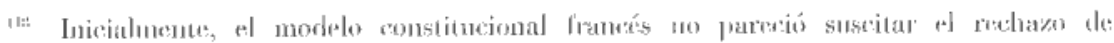

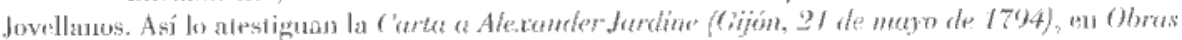

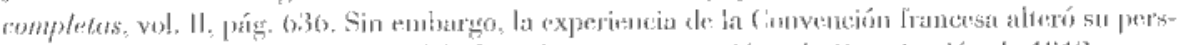

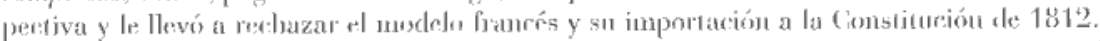

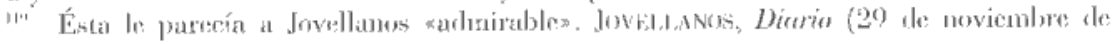
1705). Dimites, vol. II, pág. 2200.

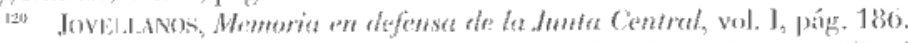

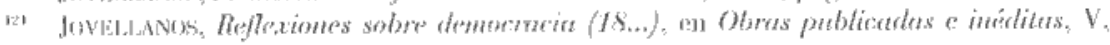
vol, I.XXXVII, 19,50, pńg. 414. 
El alán reformista de las instituciones y, por ende del sistema de yobierno que constituía su soporte, se lialla latente a lo largo de prácticamente todas sus obras. Ya en 1780, había ensalzado la importancia de las Cortes en la Constitución Visigoda yz como se ha visto, uno de los elenentos indisponibles de la Constitución histórica era la reunión de Cortes ${ }^{123}$; una renuión que la Constitución sólo podía «reconocer», nunca instaurar, puesto que se trataba de. un derecho originario de la comunidad integrado en su «supremacía».

Lstas pretensiones regeneradorés labllan un cierto freno en la colebérrima Consulta sobre la conncación de Contes por estamentos, uno de los textos más conservadores de Jovellanos. Es cierto, como afirma Baras Escolá, que también este documento contienc matices reformadores ${ }^{12 t}$, pero creemos que do menor intensidad: postula reformas, pero menos osarlas que las que a partir de ese monento defenderáles. Precisamente la Comsulta ha sido el principal documento esgrimido para afianzar la imagen del Jovellanos tradicionalista. En él afirna la soberanía det rey y deja escaso margen a una división de poderes; las Cortes no ostentan la potestad legislativa, sine un derecho de petieión, siendo la sanción regia la rue contiene y resume la facultad legilerante. Sin entuaryo, hay que tener en cuenta la real fíliación de este documento. Desde nuestro punto de vista, en la Corsulta lovellamos vierte muchiss de las opiniones plasmadas por Martínez Marima en su kinsago histórico-crítico, quizás porque en ese momento le pareció más oportuno utilizar un discurso nás conservador ante los inminentes envites de las tendencias más «democráticasn. Fsta obra de su cotreránco había sido publi-

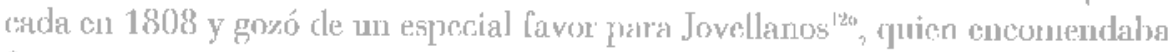
fervientemente su lectura a Lotil Holland en noviembre de ese mismo año ${ }^{127}$,

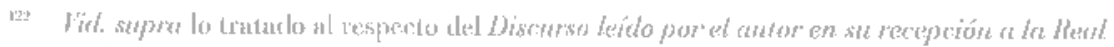
Acartemia de la Historia, de 1780 .

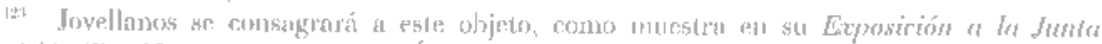

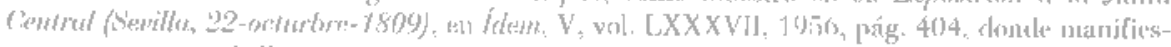

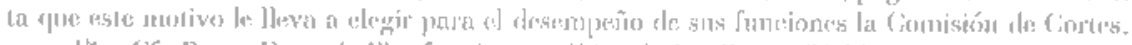

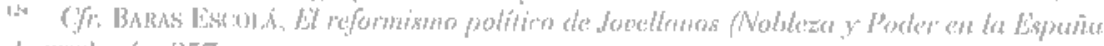
del sigh (1)in) prig. 257 .

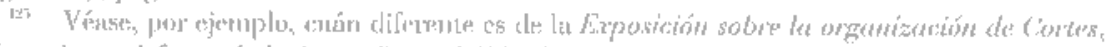

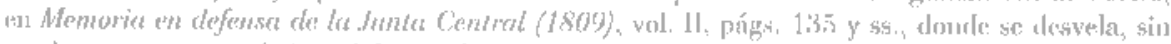
sombrus, anmo an arérrime defensor de coutes bicamerales.

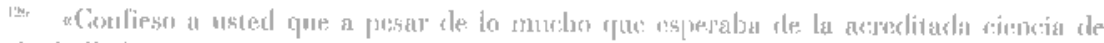

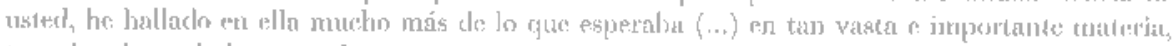

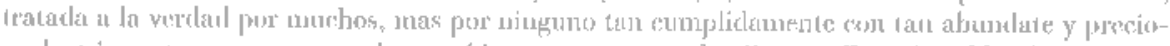

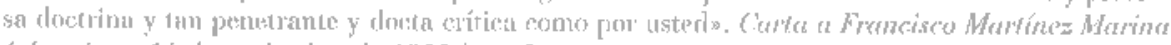

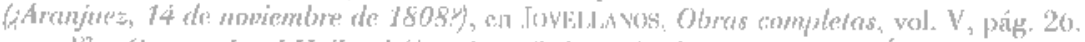

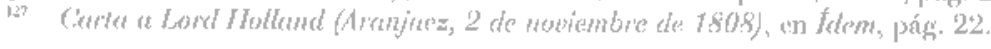


apenas seis meses antes de la producción de la Consulfa. En el Ensayo encon1ramos exactamente las mismas ideas vertidas por Jovellanos; ideas que no Labía defendido hasta el momento. El texto de Martínez Marina es claramente más moderado que su Teorí de las Cortes ${ }^{128}$, pero resulta inreresante que la Consulta de convocación, el texto más conservador de Jovellanos, se base precisamente en la obra de un autor próximo a las ideas liberales.

Por esta razón nos inclinamos a pensar que la Consulta la de tratarse con cautela puesto que es un texto coyuntural. De hecho, la Nola prinuera de los Apéndices no parece tan sólo un alegato contra la idea de soberanía nacional defendido por los liberales doceanistas, sino también, en parte, un intento de clarificar la postura constitucional manilestada en el documento de 1809 , y en ese intento realnente trastoca lo dicho, rectifica una postura que, al parecer. acabó por parecerle cxcesivamente conservadora.

Así, en la Consulie afirma la soberanía regia, y que esta soberanía no sólo supone el ejercicio del poder ejecutivo, sino también el legislativo, hasta el punto que el papel de has Corles resulta alssolutamente memado: el Rey se "aconsejaba» de las Cortes, que podían realizarle peticiones, pero la decisión última, la sanción, pertenecía al Rey ${ }^{12 n}$. El Monarca temía toda la soberanía, y ninguma parte podía, pues, desprenderse de ebla. Idéutiens proprosiciones laallamos en Martínez Marina: «El gobierno gútico fue propiamente y en todo rigor un gobiemo monárquico; y los reyes gozaron de todas las prerrogativas y derechos de la sobcranía», sin perjuicio de la convocatoria de Jumtas Nacionales. para «aconsejarse» en ellas ${ }^{1: 3 .}$. También Marina, como hará Jovellanos, dice que tales poderes no suponem que d rey fuese absoluto: «su autoridad no por eso era despótica ni arbitraria, sino templada por las leyes», leyes fundamentales

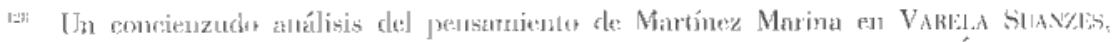

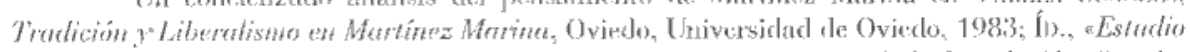

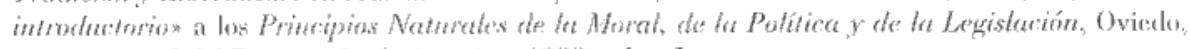
Junta feneral del Prineiparle de Asturiats, 1963, págs. T y so.

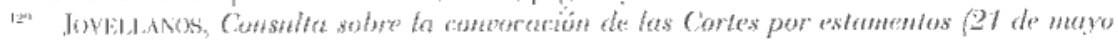

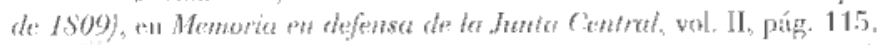

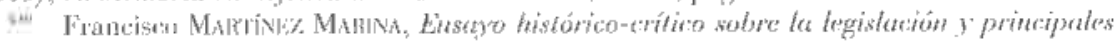

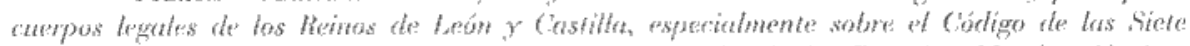

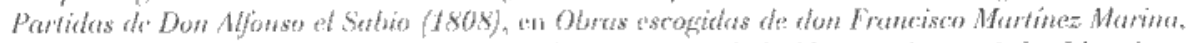

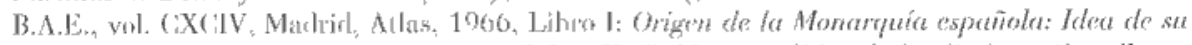

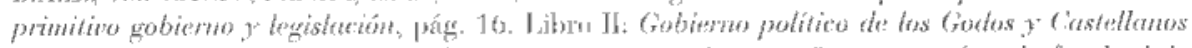

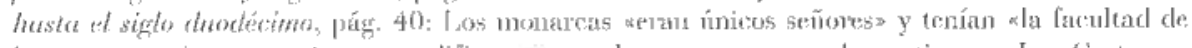

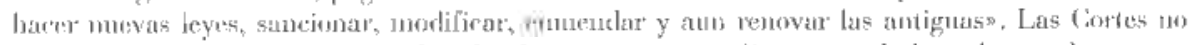

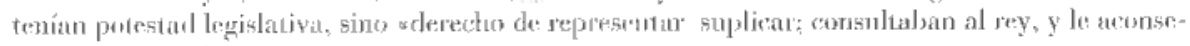
jalsans (príg. 45). 
que juraban Rey y vasallos ${ }^{1.1}$, una de las cuales, la más notable, era la que obligaba a la congregación de Cortes ${ }^{172}$. La identidad entre la opinión de Jovellanos y la de Marina es más que apreciable, no sólo en cuanto al contenido, sino incluso en la terminología.

Pero a Jovellanos esta postura lo dehió parecer en exceso conservadora, puesto que la rectificó, aum sin hacerlo expresamente. Si en la Consulfa había otorgado la potestad legislativa al Monarca, cuya sanción concentraba la facullad legiferaute, en la Memoria en defensa de la Junto Central y en la Nofu primera altera abiertamente esta idea ${ }^{m}$ : en ambas reconoce sin lugar a dudas la potestad legislativa de las Ciortes. Con tal cambio no puede sino refutar a Marina: «EI sabio Marina le atribuyó [la potestad legislativa] a nuestros reyes; yo, en mi Memoria, le arribuyo también a nuestras Gortessn ${ }^{134}$. Con esta idea se lloga incluso a plintear cuál sería el alcance que hubiera de darse a la sunción regia. En la Comisión de Cortes, segúm su descripción en la Memoria habría transigido a que fuera un derecho de sanción «absoluto o modificado» pero acaba optando por el primero ${ }^{13 z}$, en la medida que encajalba con su idea de bulanert constitution.

Si bien es cierto que fovellanos simpre pareció apostar por la reunión do Cortes, no es menos relevante señalar que la idea de bicameralismo afloró en su ctapa de la Jumta Central. Es entonces cuando las ideas de los pensadores ingleses como Lorke, Blackstore o los comentaristas del regimen auglosajón como Montesquieu y De Lolme parecen captar realnente la atención ded ilustre gijonés. En este sentido, es de destacal la importancia de la figura de I orod

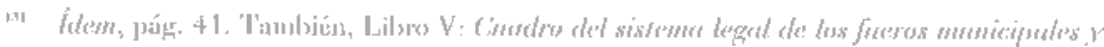

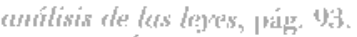

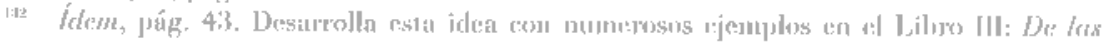

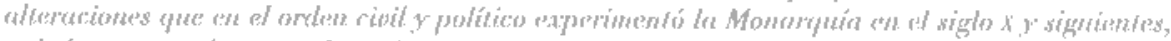

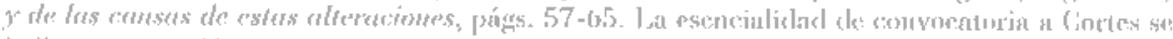

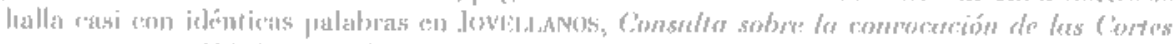

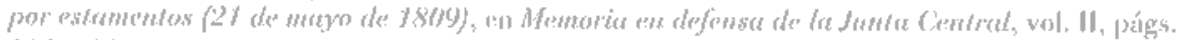
114 y 110

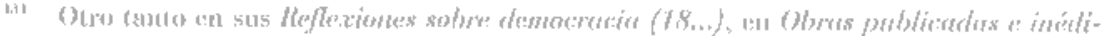

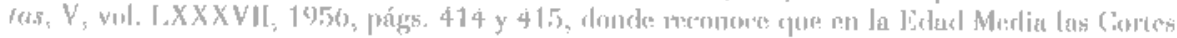

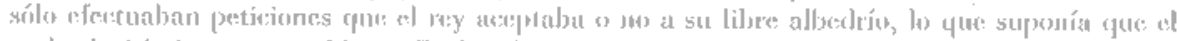

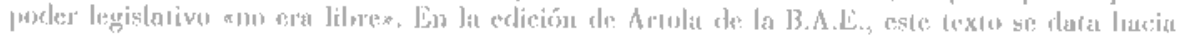

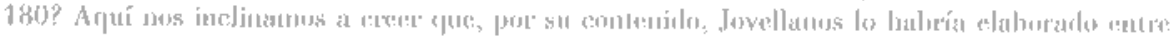
1810 y 1 1811

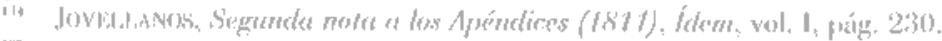

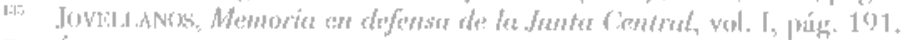

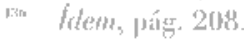


Holland, quien, creemos, fue el auténtico adalid de la conversión del asturia$n^{137}$. De hecho, aun cuando las lecturas de los autores citados cantaban bien claro las excelencias del bicameralismo, todavía en 1809 Jovellanos pide a Lord Holland que le ilustre sobre las ventajas de un tal sistema ${ }^{13 .}$. Una influencia que hay que extender a John Allen, colaborador de Lord Holland ${ }^{139}$.

Sea como fuere, lo que está más allá de toda duda es que Jovellanos lue un anglófilo convencido dentro de Ia Junta Central, como le recordarían sus colegas $^{t+1}$. Buscaba un ejecutivo fuerte, robusto, encarnado en la figura de un

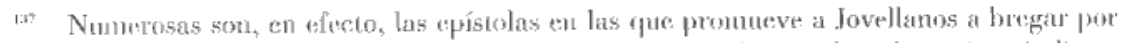

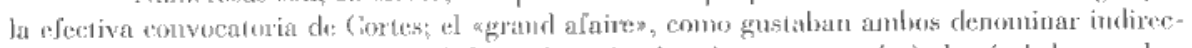

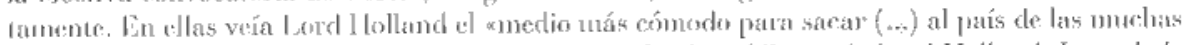

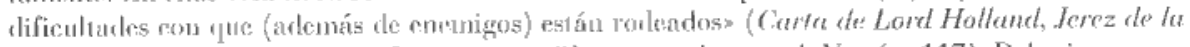

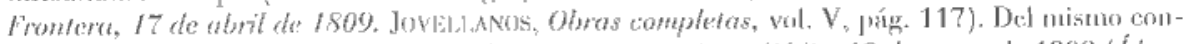

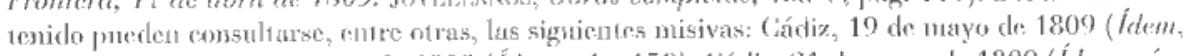

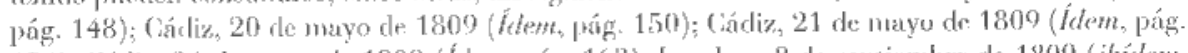
154); Cádiz, 24 de mayo de 1809 (fdem, pár. 163); Lunders, 8 de septicmbere de 1809 (ibudem. pág. 284); 1 lollaud-[ louse, 13 de dieiembre de 1809 (fdem pág. 332). Come afinna el profesor'

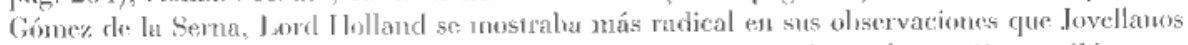

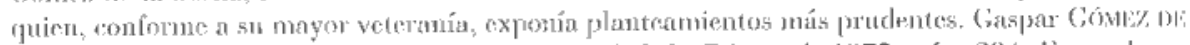

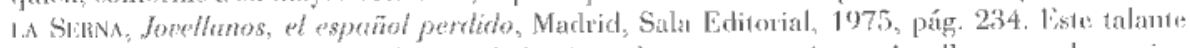
tuás liberal de lord I Iolland no le impediría, sin embag go, convenir con Jovellanos en el exeesivo

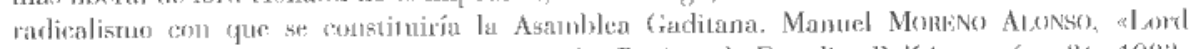
Holland y los urigenes del liberalismo español», Revista ae Estudios Políticos, núm. 36, 1983. pág. 208.

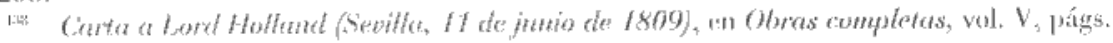
$204-205$.

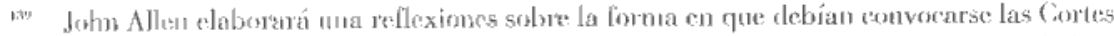

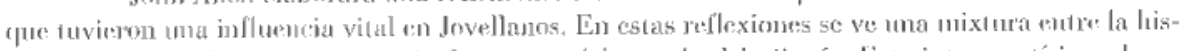
loria española y las iustiluciones inglesas, lun del agrado del gijomés. Este interesaulisino doramento, de dificil acteso, se ha publinado recientemente en edirión bilingüre con estudio prelininar

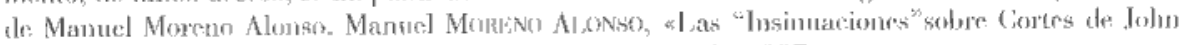

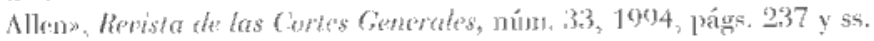

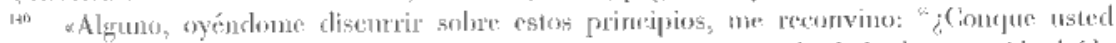

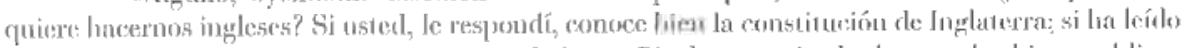

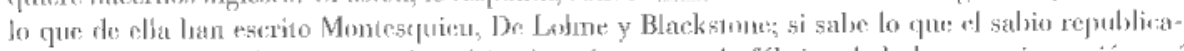

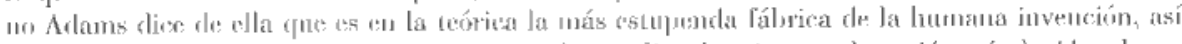

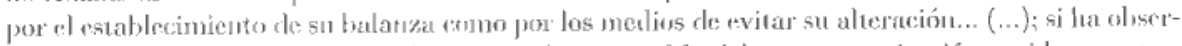

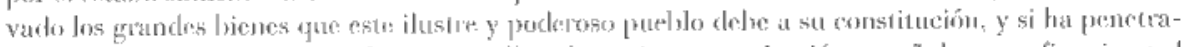
do las grandes analogías que hay curre elia y la antigua comstitución española, y en fin, si usted

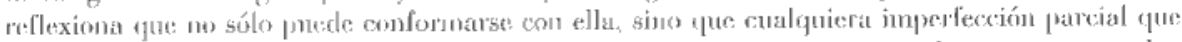

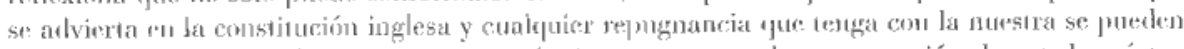

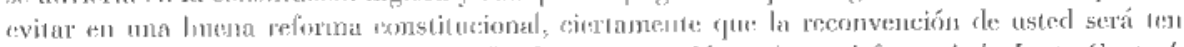

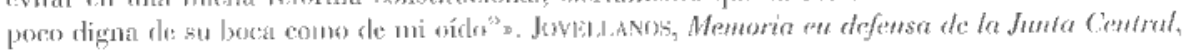
vol. 1, pág. 192. 


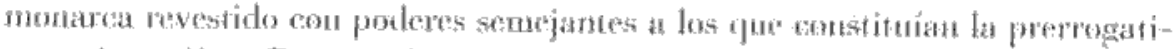

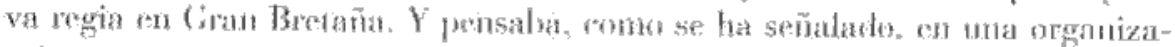

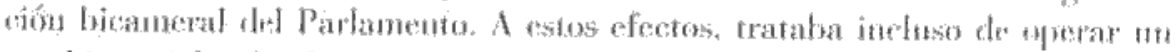

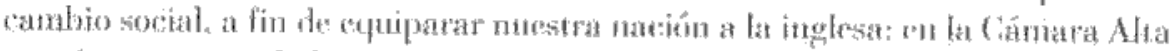
estaría represcntarla la nobleza, pero esa nobleza debía alterarse, debía constituir un título accesible a todo el pueblo, como sucedía en Albión. Una idea característica de otros intentos de plasmar el modelo inglés en suelo extraño. como ps d caso de Marlame De Siapel

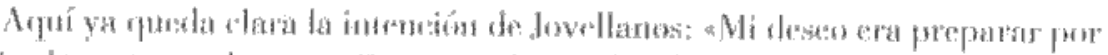

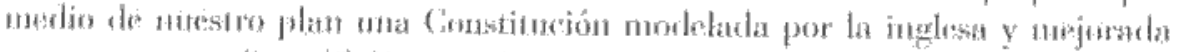

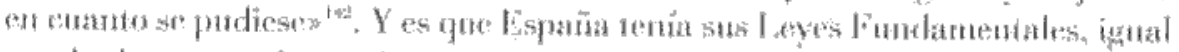

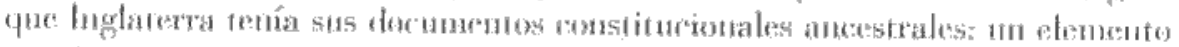
común. Al parecer de Jovellanos, sólo laltaba initan la forma de gobierno.

De todo lo dicho se desprende, sin embargo, que el polígrafo de Cijón no luabía asimilado el régimen inglés lal y urruo existín en esos momentos en la islal verina. Dicho en térninos constitucionales, Jovellanos interpretó el régimen inylis rem alave de Monarguia Comstimcional, tal y como describran los antores ‘uw: el gijoriés inás admiraba: Montesquiew, De Lolme, Locke, Blackstone.,

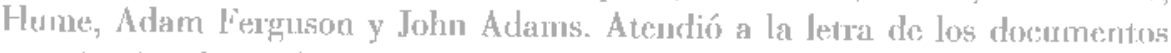

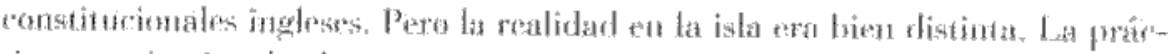

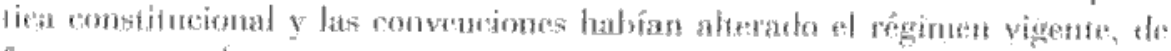

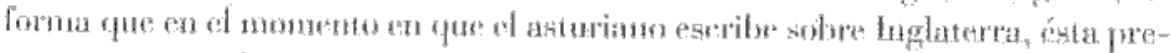

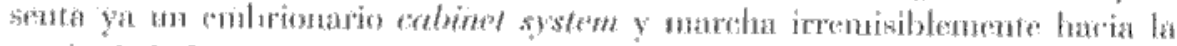
benda de la Monaroura Parlamentaria.

No carecía de datos sobre esta transformación el asturiano. Vinde las oblas de su bibliotera se hallan las de Burke, Thomas Paine, y los discursos parlamentarios de Pitt el Jomen, Fox y Sheridan, sin contar con las sustanciosas

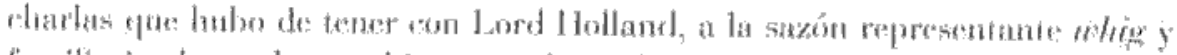

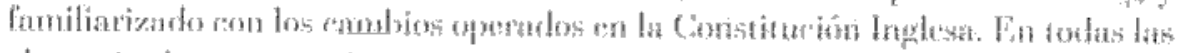

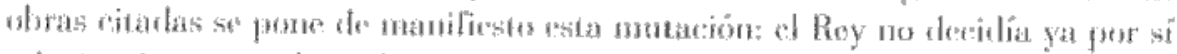

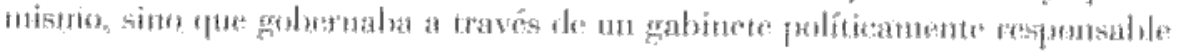

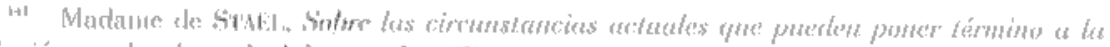

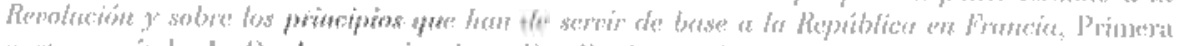

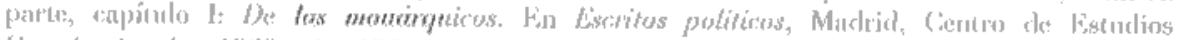
('onstitucionales, 19003, ping 108.

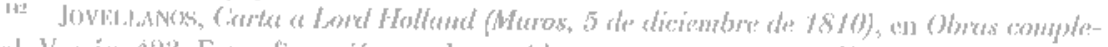

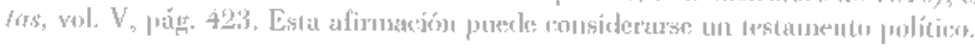


ante los Commes, cámara que llevaba el peso de la vida parlamentaria y en la que cobraban especial interés los partidos políticos.

Pero en Jovellanos no hay ma sola referencia al gabinete; antes bicn, el Monarea segúa siendo el titular, el poderoso titular, de la potestad ejecutiva. Tampoco otorgaba especial relevancia a la Cámbara Baja, sino que mantenía la juled de equilibrio entre los dos órganos ded Parlamento. Fimalnente ni una sola palabra sobre partidos políticos. Quizús viera en ellos una desvirtuación, una corrupción y no una auténtica tendencia.

FCuánta diferencia con Burke, que afirmaba la nocesidad de fue los ministros contaran con la confiamza de los Comunes, y no sólo con la regia! ${ }^{1+3}$ ¿Qué abismo seporra las ideas de fovellamos de la realidad inglesa que traslucen los discursos de Pitt y Fox, donde se pone de maniliesto la responsabilidad de los ministros anre la Cámara Baja; donde queda de relieve una realidad tan distinta de la que plasmaran Montesquien o Blackstone! ${ }^{\text {t+ }}$; Y qué no decir de sus diferencias con Thomas Paine, para quitn el auténtico Rey en Inglaterra era el gadjinete ministerial! th

\section{CONSIIERACIONLS FINALES: LA INTERPRETACION ILUSTRADA IDE JOVELLANOS}

Tras todo lo anterior la pregunta queda en el aire jidónde nficar el ideario político de Jovellanos? Desde nuestro modesto punto de vista, aun cuando no puede afirmarse una filiación clara, Jovellanos no encaja en algumos de los moldes en que se le ha querido ver.

No se trata de un partidario del Despotismo llustrado, como demuestra su liberalismo económico (expresión, en última instancia, del fin tuitivo del Estado que justificaba su misma creación) y su tendencia de hacer que el Rey compartiera el poder con unas Cortes. el despotismo sólo puede sostenerse

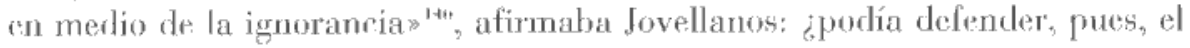

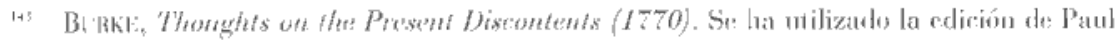

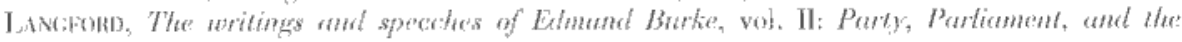

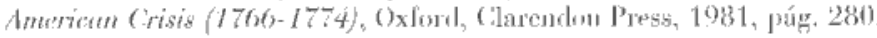

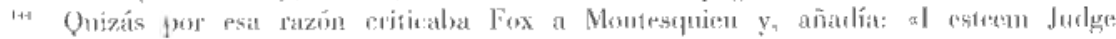

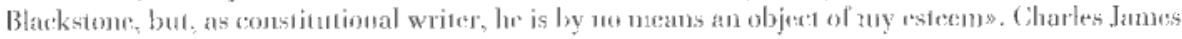

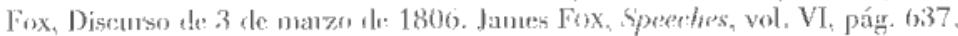

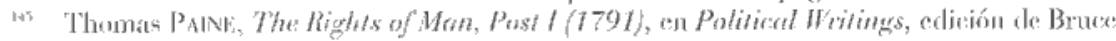
Kuklick, (ambriklge University Press, 1989, pág. 138.

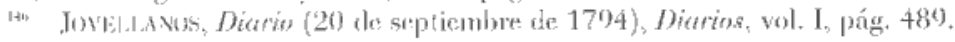


poder absoluto del rey quien no pensaba sino en instruir al pueblo? Bien es cierto que quería un Ejecutivo robusto, como lo buscaba también Locke, pero controlado por unas Cortes titulares de un poder legislativo que era expresión de la voluntad general, idea ésta tomada de Rousseau (aumque matizada, como se verá). Resulta bastante significativo que en todo un Elogio de Carlos $/ I$. Jovellanos incluya referencias a la antigua representación popular ${ }^{1+7}$.

Tampoco era el asturiano un tradicionalista, puesto que, amante de la hisLuria no tenía una concepuón pétrea de la misma. La historia infomaba, no estatuía, toda vez que siempre quedaba el progreso, la nejora a partir de la experiencia y la razón.

Es difícil ver en Jovellanos un escolástico por su discrepancia con esta escuela y por su adscripción firme y decidida al iusnaturalisno racionalista, que conoció desde temprano (ya en Sevilla: abiertas las puertas a la "luz" por Olavide) y profesó durante sus días. En efecto, a tenor de sus ideas sohre cl origen del Eatarlo y la sociedad sólo cabe concluir que su principal filiarión ti ef iusnaturalismo racionalista, esencialmente germánico, pero también francés e inglés. Una mirada más atenta centrá la cuestión en un autor clave: Pufendorf ${ }^{1+\%}$. Así, Jovellanos distingue entre el pacto social o ley fundanental, origen del Estado y la sociedad, y el monento de selección de la forma de gobierno a través de la Constitución. Puferzdorf, tambićn diferenciaba entre la formación de la sociedad y el Estado (rgreements) y la deceminación de la forma de gobierno (decree $)^{1+n}$.

Es cierto que algunas límeas del pensamiento jovellanista parecen orientarse hacia el escolasticismo, como es la idea de soriabilidad, el organicismo o

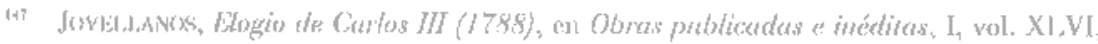
pág. +312 .

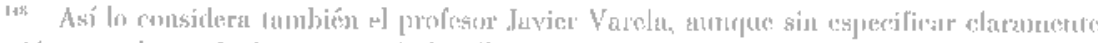

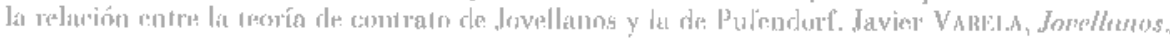
prig. 24 ').

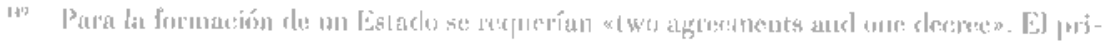

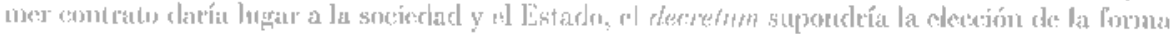

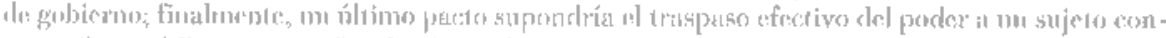

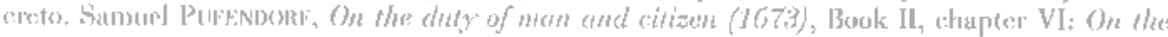

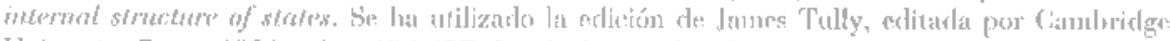

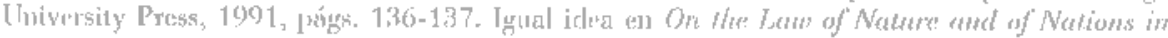

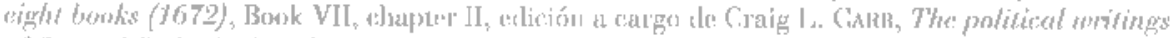

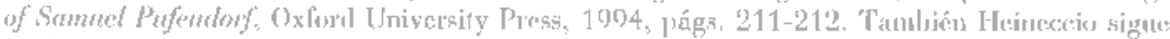

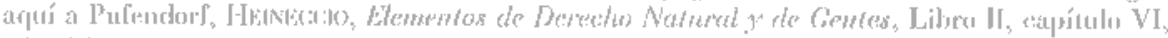
pang. 264. 
su conceprion del derecho de resistemeia. Pero la inlluenta, an su caso, no es

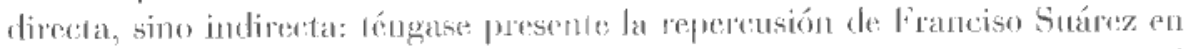
torlo el pensamiento iusnaturalistal, compezando por Cirocio y terminando por el propio Sammed Pufendorfi. Así, la idea de sociabilidad la dedendían práctionmente todos los antores atmirados por Jovellanos y representantes del iusna-

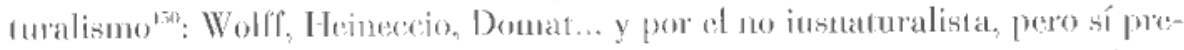

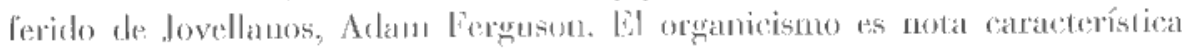

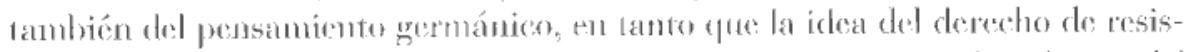
tencia como reserva de podes por la commendad pata reprimir los abousos del monarea se: hallat en entores como Huge Geocions, sin descartar ma idea loas-

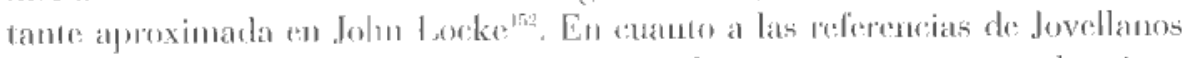

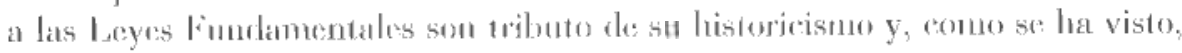
de la inlluencia de Marina más que del influjo escolástico.

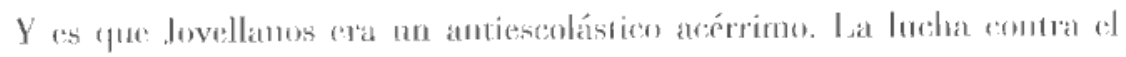

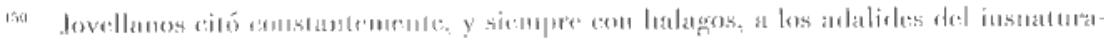

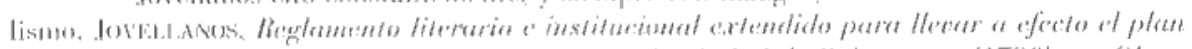

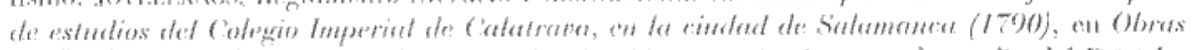

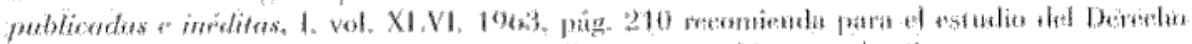

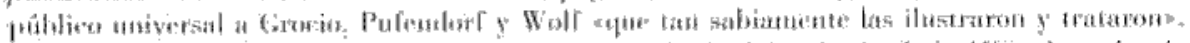

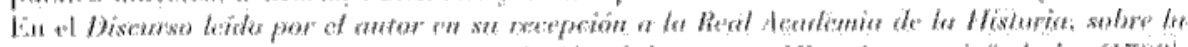

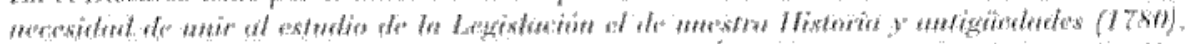

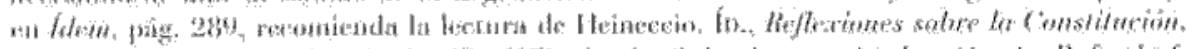

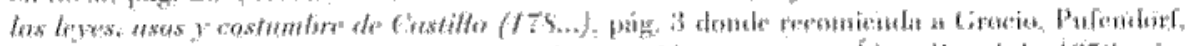

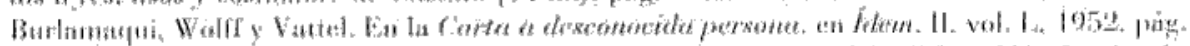

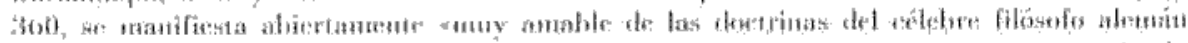

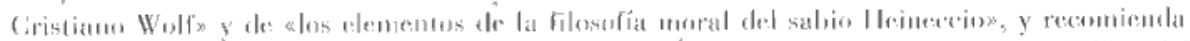

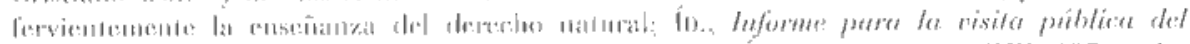

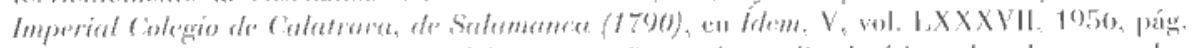

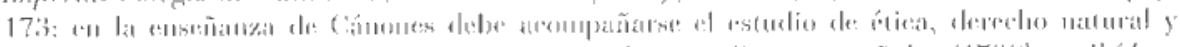

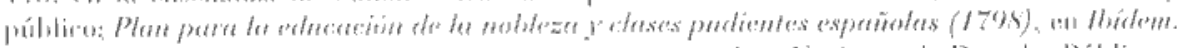

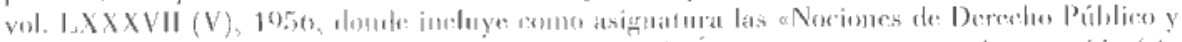

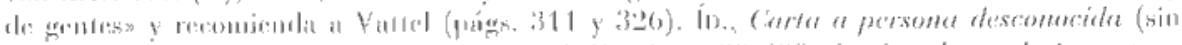

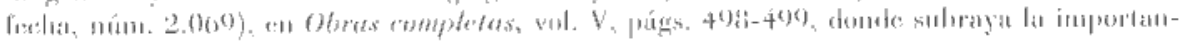

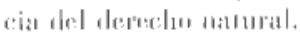

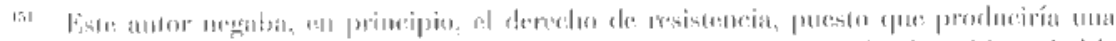

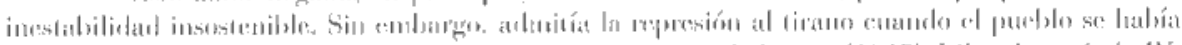

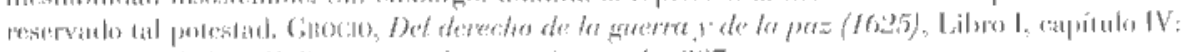

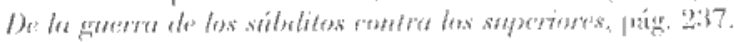

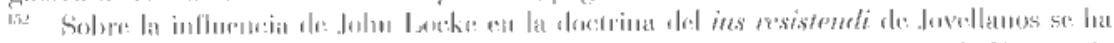

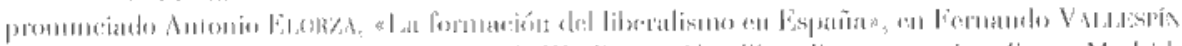

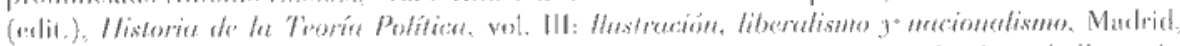

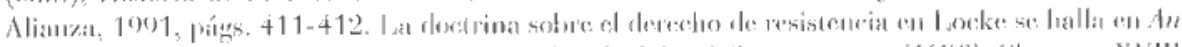

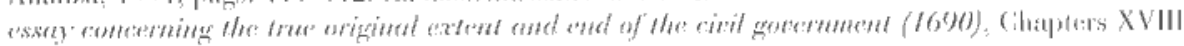

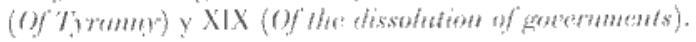




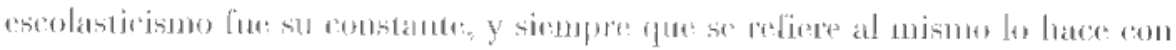

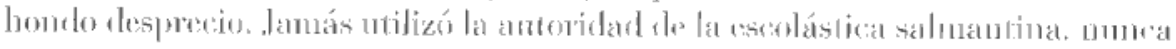

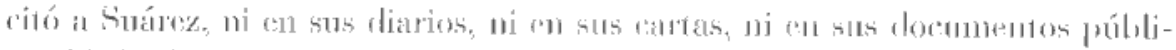

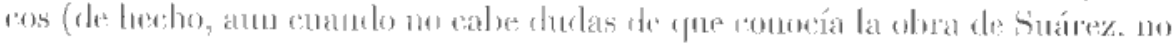

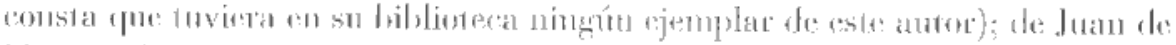

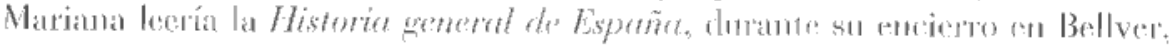

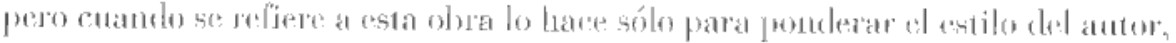

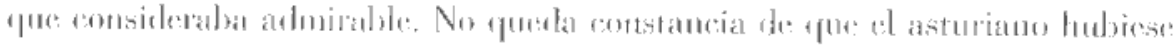

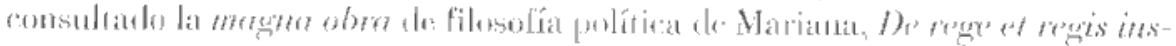

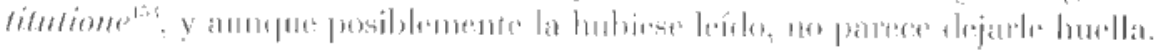

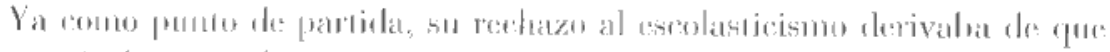

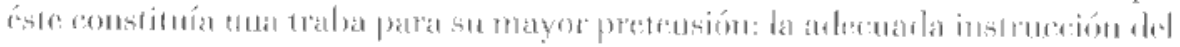

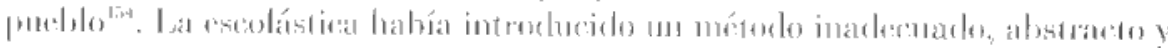
exelesivamente racionalista

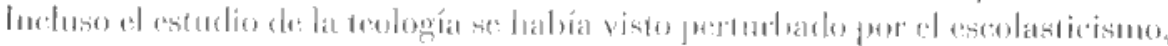

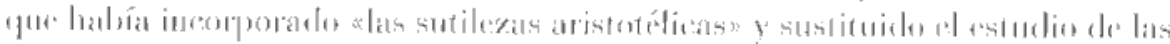

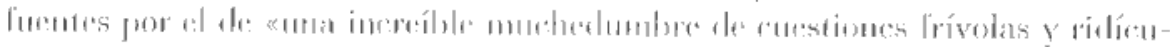

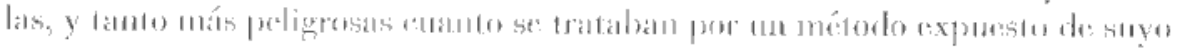

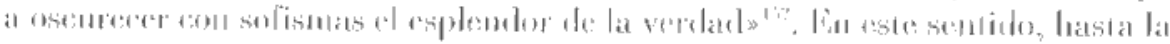

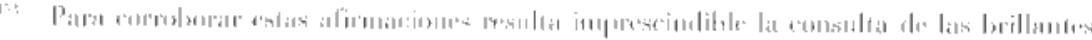

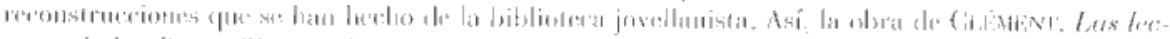

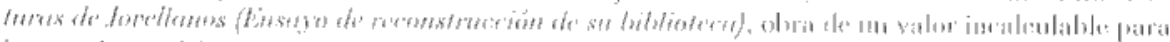

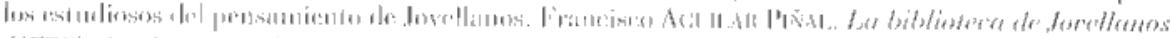

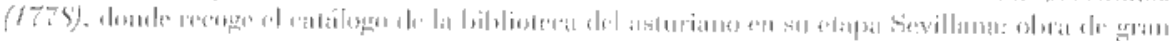
importame

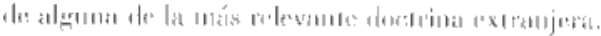

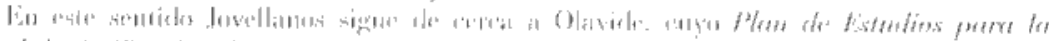

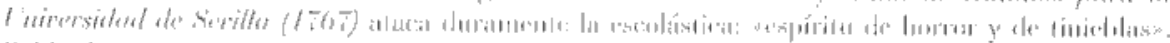

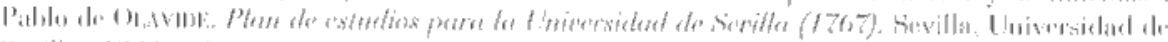

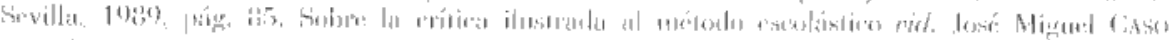

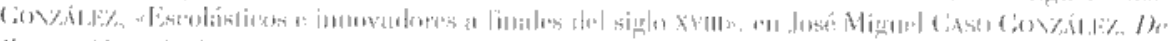

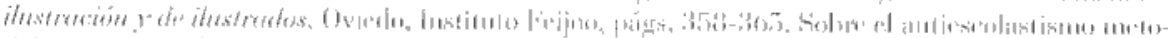

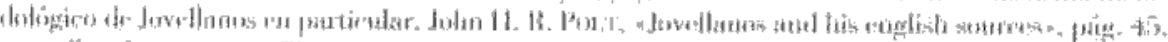

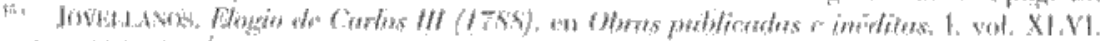

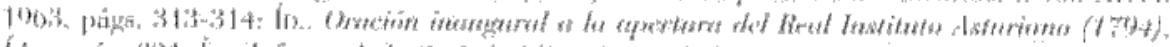

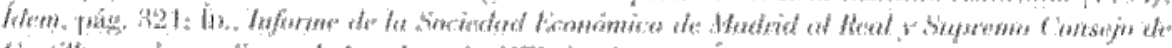

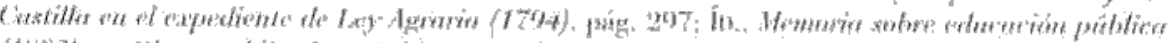

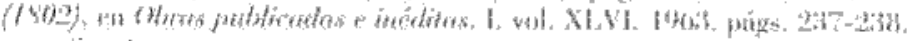

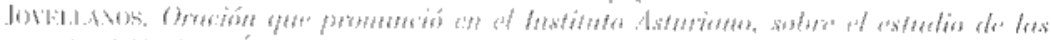

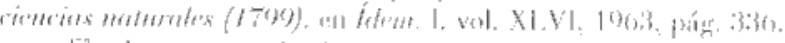

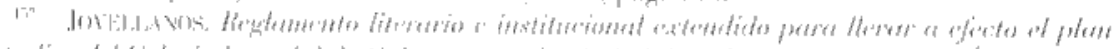

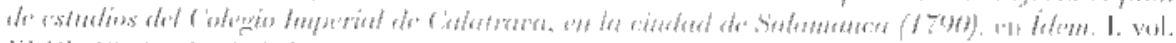

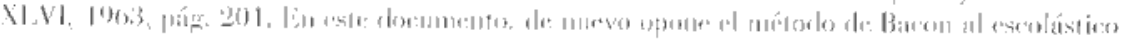


obra de Santo Tomás, Suma Theologica, resulta viciada por su adscripción al peripato «cuyo general destierro no puede estar muy distantes ${ }^{1.5}$. Y es que era preciso un cambio, hacer desaparecer uhasta los títulos de tomistas, escolistas, suarecistas»; sustituir el «yugo aristotélico», y los «laberintos del arbitrio y opinión» del escolasticismo por «la enseñanza de la ética, del derecho natural y público» ${ }^{15 \%}$. Otras naciones se habían deshecho ya del «hijo mal nacido* del peripato y si España no ln había hecho todavía "no es porque no esté ya dispuesta a entrar en el buen senderon ${ }^{160}$.

Este rechazo de la escolástica le lleva a lamentarse de sus antiguos estudios: "Me dediqué después a la filosofía»-afirma ya en 1780- "Entré en la jurisprudencia sin más preparación que una lógica hárbara y una metafísica estéril y confusa»"; " ¿ Cuánto tiempo perdido en estudios estériles! " "La crítica se perpetúa, y se manticne con la entrada del nuevo siglo ${ }^{16.1}$ y, en 1809 , propone un plan de educación a la Junta Central en la que sigue atacando veladamente la cscolásica y se mantiene firme en su adhesión al iusnaturalismo. citando como ejemplo, ulla vez más, a Wulfíl't.

Pero rechazar la imagen tradicionalista y cscolástica de Jovellanos no implica necesariamente adseribirlo al movimiento libcral. Sin duda se halla lejos del liberalismo democráico. Como es bien sabido, el pacto social de: Rousseau supone poner en común el porler individual, sujetándolo a la volun1ad geueral, que se convicre así en sobcrana. Para la concepeión liberal-democrática constuida sobre estas premisas, la soberanía se atribuye al pueblo como suma de individuos soberanos, una vez producida la renuncia plena de los derechos subjetivos individuales en lavor ale la voluntad generalón. Ésta

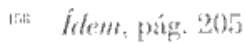

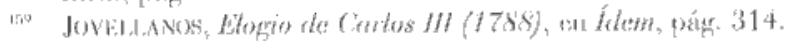

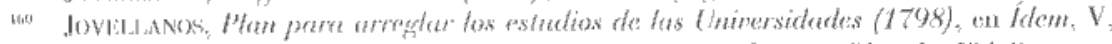

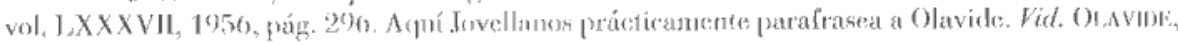

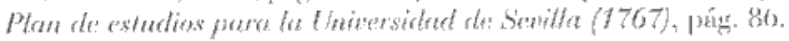

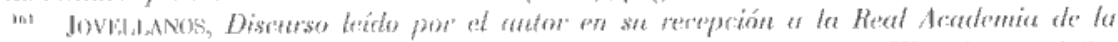

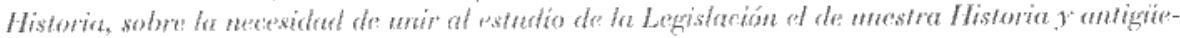

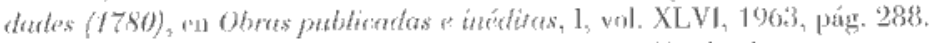

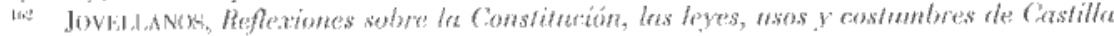
(178:) páng. 33.

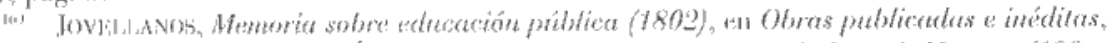

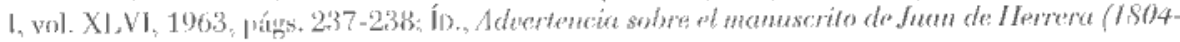
ls(0), an Ibidem, vol. 1. (6I), 1952, pág. 497.

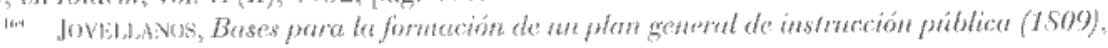
(1) I. vol. XLVI, 1903 , pág. 271.

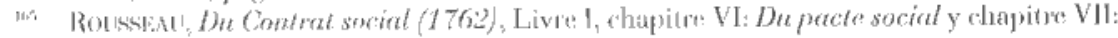
Dh soumeruin, píg.s. 24:3-245. 
resulta inajenable, por lo que tan sólo el pueblo puede expresarla (denocracia (livecta); ahora bien, resultando tal circunstancia imposible en los grandes Estados, se recurre a la democracia representativa: exclusivamente el Parlatmento, en cuanto formado por los diputados electos por el pueblo puede. expresar la voluntad general, esto es. la ley. De aquí, el pensaniento revolucionario francés llegó a un régínen de corte asambleario, que plasmó parcialmente (imbricado con la idea de Montesquieu de separación rígida de poderes) en la Constitución de 1791 y do forma manifiesia en la Convención ${ }^{1 a t}$. In nodelo que se distanciaba de la idea que vertiera Rousseau en su Conurat social, y se accreaba más a la postura que el ginchino defendierén en las Comsideraciones sobre el gobientes de Polonian.

Jovellanos distaba de todas estas ideas: el Estado no nacía u partir de una renuncia plena de derochos, sino parcial, y el soberano no era realmente la voluntad general (y la ley como expresión de ésta), sino que la soberanía se nulizaba para designar al titular del poder ejecutivo. Desde esta perspectiva, las leyes no las elaboraba sólo el Parlamento, sino tam-

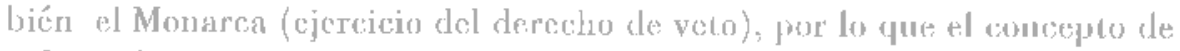
voluncad general que ubiliza dovellanos no es idéntion al rusoniauo. Por ot:a parte, como se ha visto, Jovellamos nostulaba incondicionalnente un sistoma de Monarquía mixta, absolutarnente jucompatible con el modelo asambleario revolusiomario francés, ques el astimiano recliasabatin, lo que

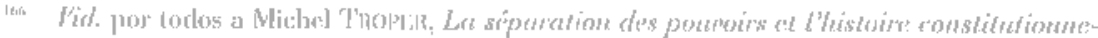

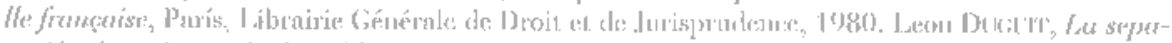

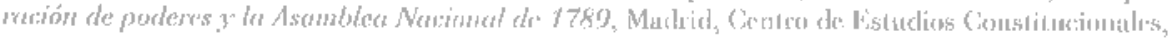

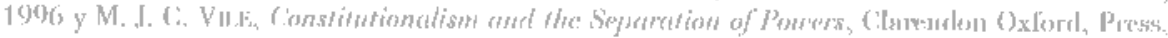
1960), páçs. 180 y st.

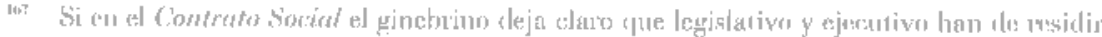

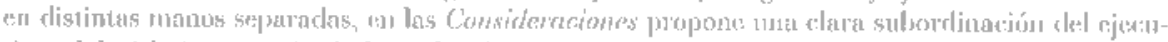

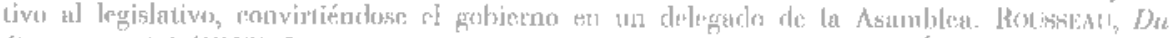

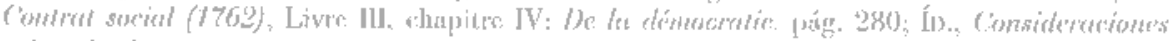

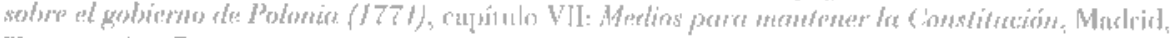
Toumes, págs. 78 y sa.

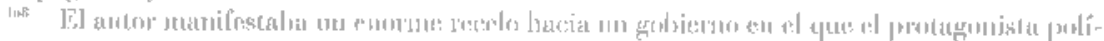

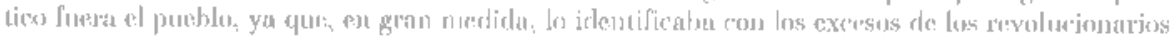

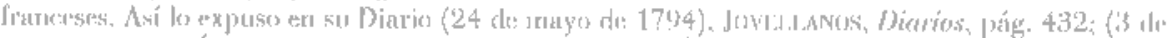

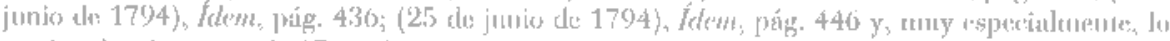

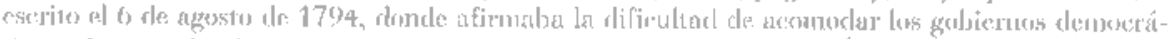

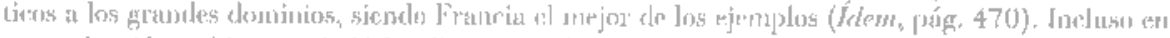

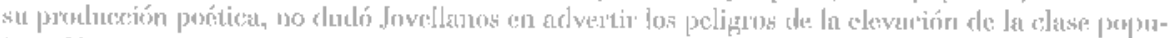

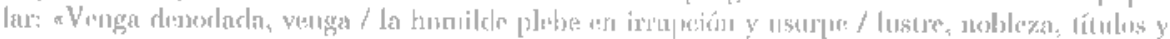

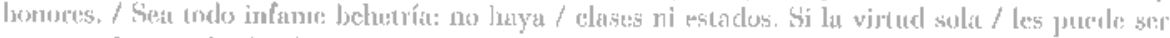

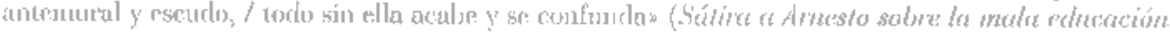


le Ilevó a criticar la imitación que del mismo efectuahan los diputados gaditanos ${ }^{1, n}$.

Desde esta perspectiva no podría definúrsele conı un liberal en el mismo sentido qut se utiliza para designar a sus coetáneos participes en la elaboración de la Constitución de Cádiz. No se olvide que cl concepto político de «liberal» se acuña en Cádiz, en 1812. El ideario que identificaba a quicnes por aquel entonces acaparaban tal epíteto partía de la Soberanía Nacional, la idea de poder constituyenre (tomada de Sieyès) y la elaboración de una nueva Constitución a través de la cual se podía alterar no sólo la lorma de gobierno (como de hecho se hizo), sino la misma forma del Estado ${ }^{17 n}$; una Constitución que recogía y garantizaba los derechos y libertades naturales de los ciudadanos. No hace falta repetir cuán disranciadas se hallaban estas ideas del pensaniento jovellanista. Por oira parte, el escritor gijonés difería de los liberales en dos conceptos básicos en el ideario de estos úlimos: libertad o individualisino. En cfecto, para Jovellanos las libertades no cran simples privilegios paciados entre el rey y el reino y plasmados en las Leyes Fundamentales (concepción escolástica), pero tempoco eran aquellas libertades absolutas que el liberalismo americano y francés había recogido en las célebres Declaraciones de Derechos. La filosofía políica que informa estas últimas concibe los derechos como absolutos en cuanto preestales y presociales: en el estado de naturaleza, que toman como punto de partida, el individuo poséa derechos subjetivos ilinitados. Sin embargo, al entender Jovellanos que el estado natural del hombre era la sociedad (natural), la cousecuencia es que los derechos subjeti-

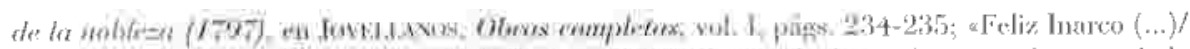

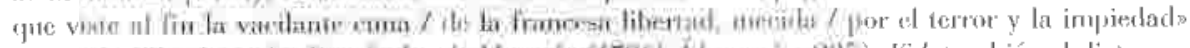

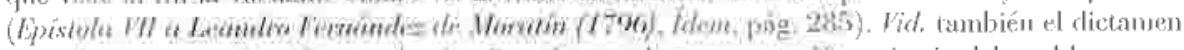

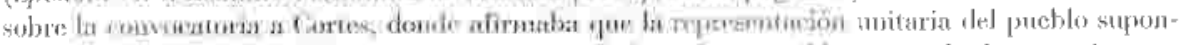

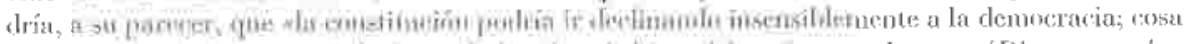

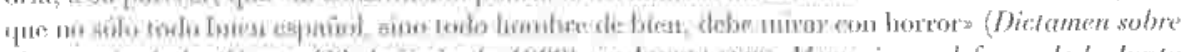

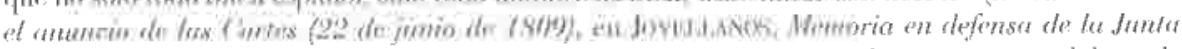
(entral, pár. 111). Este copíritu moderado be ve de forma diátana en las siguiestes palabras de

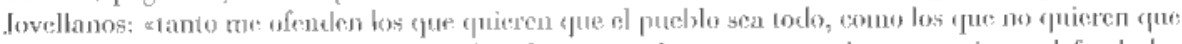

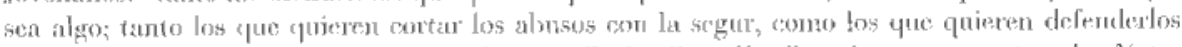

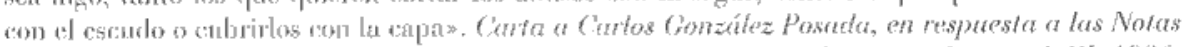

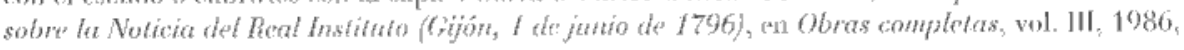
pág. 228 .

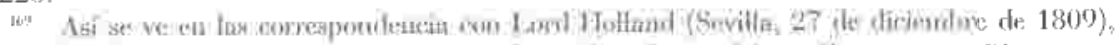

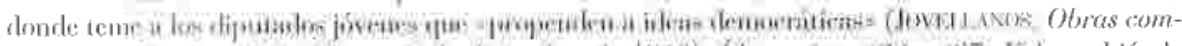

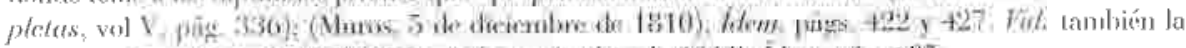

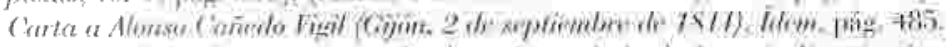

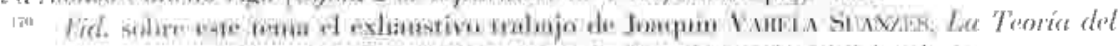

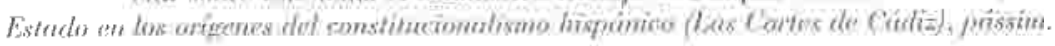


vos no resultaban absolutos, sino socialnente linitados, y además tenían como contrapartida obligaciones sociales. Por lo que se refiere al individualismo (lípicamente liberal), éste tona forma en la teoría pactista del asturiano, pero claudića una vez construido el Estado, en el que los sujetos se integraban de forma jerarquizada ${ }^{121}$, aspecto básico para su concepción del gobierno nixto en el que, como es bien sabido, resultaban impresciudibles los asuerpos intermedios», según había expuesto Montesquieu.

Trazar los límites de la ilustración y el liberalismo es complejo puesto t pue, como dice John Gray, rurante el siglo Xvit «la historia del liberalismo en Europra continental y la difusión de la Ilustración deben ser vistas como aspectos de una misma corriente de pensamiento y préctica»" Sin embargo, creemos que Jovellanos scría tau sólo un liberal si se entiende a la inglesa y en la línea de Burke, al que vinculaba la idea de Constitución histórica, el rechazo del valor absoluto de la razón, la regación do "derechos naturales", en fin, su actiud críticá hacia el proceso revolucionario francés. A esta perspectiva abundaría el hecho de que el ideario jovellanista constituye ur precerdente del ulterior liberalismo conservador decimonónico español ${ }^{17: 5}$. Sin embargo, distancian a Burke y a Jovellanos una muy distinta concepción de los principios rectores de las relaciones entre Fjecutivo y I equislativo, gue hacen del inglés un tcórico dè parlamentarismo y del sistema de partidos, rosa gue no se puede decir en absoluto del asturiano.

El momento clave: que erea mayores dudas para calificar a Jovellanos as la entrada del siglo XIX y, especialmente, la Guerra de la Independencia. Tis crifonces ruando más controversias suscita su person ¿liberal? Ztradiciunalista? Si no hubiese vivido esa época prúcticamente nadie dudaría en afirmar que Jovellanos sicmpre fue un ilustrado. Yesa es la calificación que cremos que debe dárscle. I us albores del siglo XIX ámizaron, modelaron on cienta medida, el icloa-

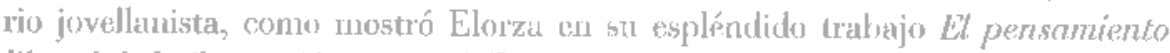
liberal de la ilustración española ${ }^{174}$, pero en el fondo d gijonés seguía sierndo, en sus principios esencjales, min ilustrado. Lo que equivale a decir un refornista.

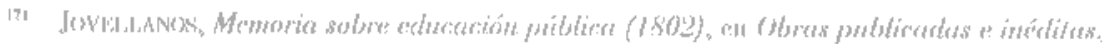
1. vil. XI,VI, 196,3. píng.250.

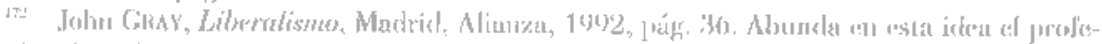

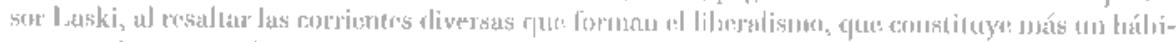

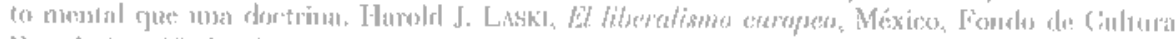

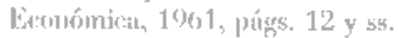

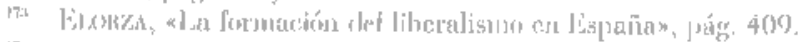

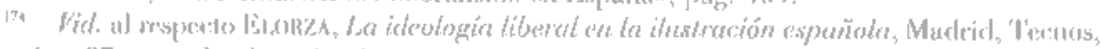

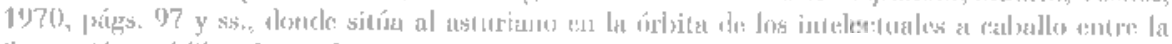

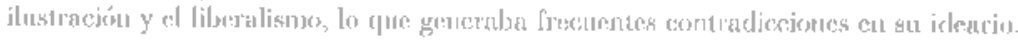

